Prepared in cooperation with the U.S. Army Corps of Engineers, Fort Worth District; City of Corpus Christi; Guadalupe-Blanco River Authority; San Antonio River Authority; and San Antonio Water System

\title{
Sources of Suspended-Sediment Loads in the Lower Nueces River Watershed, Downstream from Lake Corpus Christi to the Nueces Estuary, South Texas, 1958-2010
}

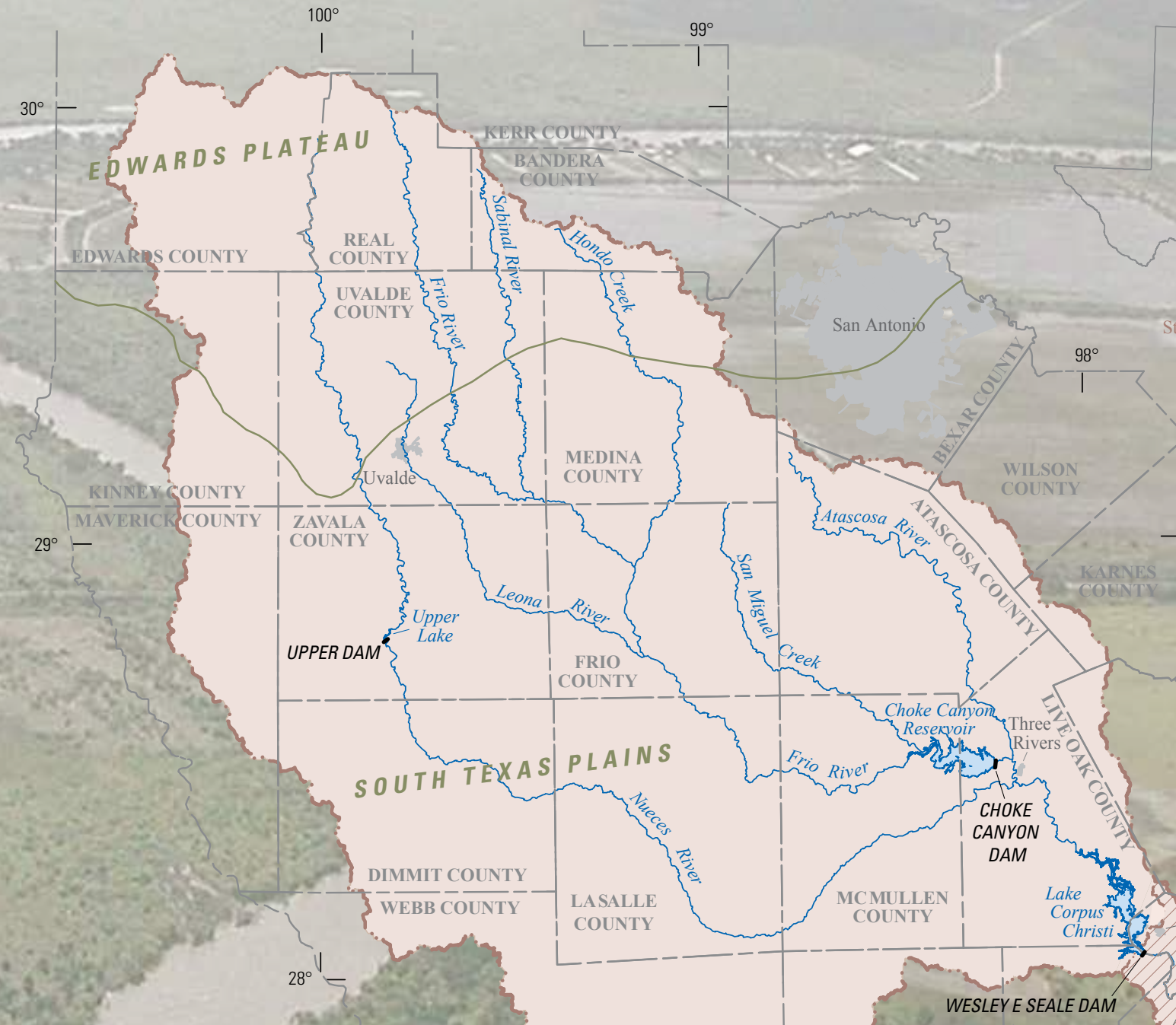

Scientific Investigations Report 2013-5059 
Cover: Aerial photograph of the Nueces River and Nueces Estuary downstream from Interstate Highway 37, near Corpus Christi, Texas, May 21, 2004 (photograph by Dr. Carlos Fernandez, Texas AgriLife Research and Extension Center at Corpus Christi, Texas). 


\section{Sources of Suspended-Sediment Loads in the Lower Nueces River Watershed, Downstream from Lake Corpus Christi to the Nueces Estuary, South Texas, 1958-2010}

By Darwin J. Ockerman, Franklin T. Heitmuller, and Loren L. Wehmeyer

Prepared in cooperation with the U.S. Army Corps of Engineers, Fort Worth

District; City of Corpus Christi; Guadalupe-Blanco River Authority; San Antonio River Authority; and San Antonio Water System

Scientific Investigations Report 2013-5059 


\section{U.S. Department of the Interior \\ SALLY JEWELL, Secretary}

\section{U.S. Geological Survey \\ Suzette M. Kimball, Acting Director}

U.S. Geological Survey, Reston, Virginia: 2013

This and other USGS information products are available at http://store.usgs.gov/
U.S. Geological Survey
Box 25286 , Denver Federal Center
Denver, CO 80225
To learn about the USGS and its information products visit http://www.usgs.gov/
1-888-ASK-USGS

Any use of trade, product, or firm names is for descriptive purposes only and does not imply endorsement by the U.S. Government.

Although this report is in the public domain, permission must be secured from the individual copyright owners to reproduce any copyrighted materials contained within this report.

Suggested citation:

Ockerman, D.J., Heitmuller, F.T., and Wehmeyer, L.L., 2013, Sources of suspended-sediment loads in the lower Nueces River watershed, downstream from Lake Corpus Christi to the Nueces Estuary, south Texas, 1958-2010: U.S. Geological Survey Scientific Investigations Report 2013-5059, 56 p. 


\section{Contents}

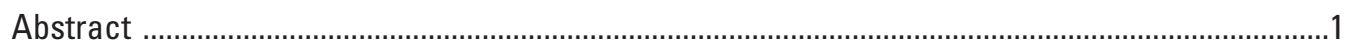

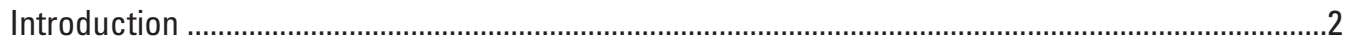

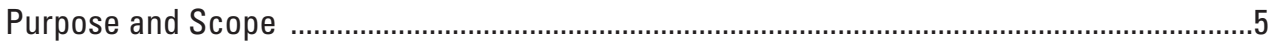

Description of the Lower Nueces River Watershed ...........................................................

Suspended-Sediment Concentrations and Loads of the Lower Nueces River ..................................

Review of Historical Suspended-Sediment Data and Studies in the Lower

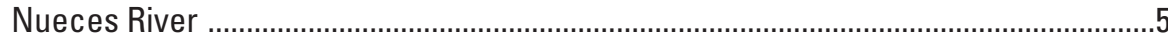

Recent (2006-7 and 2010) Suspended-Sediment Sampling...................................................

Simulation of Streamflow and Suspended-Sediment Concentrations and Loads of the Lower Nueces River Watershed .......................................................................................10

Functional Description of Hydrological Simulation Program —FORTRAN .............................10

Previous Watershed Modeling Study and Report ................................................................12

Input Data for the Lower Nueces River Watershed Model ...................................................15

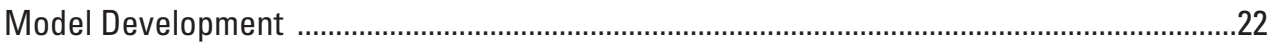

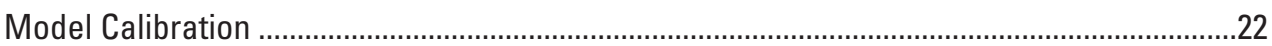

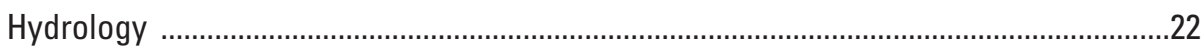

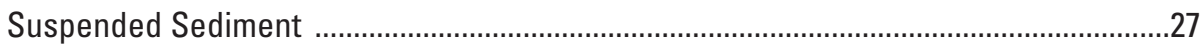

Estimation of Suspended-Sediment Loads from Lake Corpus Christi .....................27

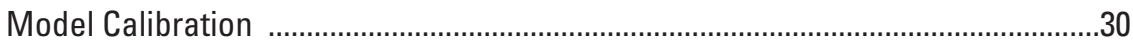

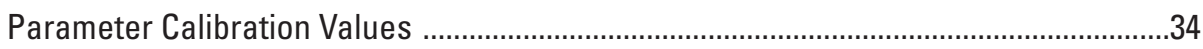

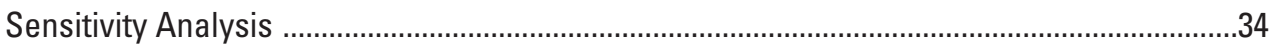

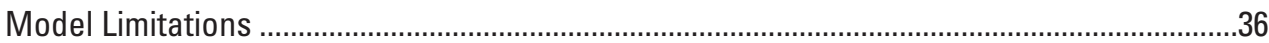

Estimated Suspended-Sediment Loads, by Source, to the Nueces Estuary, 1958-2010 ..................36

Estimated Suspended-Sediment Yields by Subwatershed for Selected Runoff

Events during 2009-10 .....................................................................................................

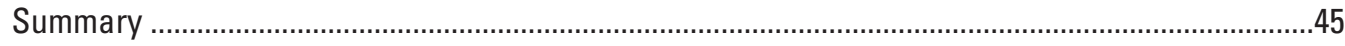

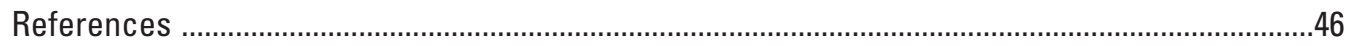

Appendix 1. Hydrological Simulation Program-FORTRAN (HSPF) Parameters Used to Simulate Hydrologic and Sediment Processes in the Lower Nueces River Watershed, South Texas

\section{Figures}

1. Map showing location of Nueces River Basin, including lower Nueces River study area, south Texas .3

2. Map showing location of lower Nueces River watershed, south Texas ...........................

3. Graph showing annual suspended-sediment loads for the Nueces River near Mathis, Texas, 1942-57 and 1962-82

4. Diagram showing hydrological Simulation Program-FORTRAN (HSPF) flowchart for hydrologic processes on $A$, impervious and $B$, pervious land segments

5. Diagram showing hiagram showing Hydrological Simulation ProgramFORTRAN (HSPF) flowchart for sediment processes on $A$, impervious land segments, $B$, pervious land segments, and $C$, stream reaches 
6. Map showing land-cover categories in the lower Nueces River watershed, south Texas

7. Map showing surficial geology of the lower Nueces River watershed, south Texas

8. Map showing relative soil infiltration rates in the lower Nueces River watershed, south Texas

9. Map showing subwatershed delineation for the lower Nueces River watershed model, south Texas

10. Map showing locations of U.S. Geological Survey streamflow-gaging stations and National Weather Service rainfall stations (with associated Thiessen rainfall areas) providing data for the lower Nueces River watershed model, south Texas .......21

11. Graphs showing measured and simulated daily mean streamflow at U.S. Geoloical Survey streamflow-gaging station 08211000 Nueces River at Bluntzer, Texas, 2005-6

12. Graphs showing measured and simulated 7-day mean streamflow at U.S. Geoloical Survey streamflow-gaging station 08211500 Nueces River at Calallen, Texas, 2001-10

13. Graphs showing relation between streamflow and suspended-sediment load and plot of regression error residuals based on 22 streamflow-load data pairs from 08211000 Nueces River near Mathis, Texas, 1964-71 and 2006-7

14. Graphs showing relation between streamflow and suspended-sediment load and plot of regression error residuals based on 10 streamflow-load data pairs from 08211500 Nueces River at Calallen, Texas, 2006-7

15. Graph showing estimated annual streamflow and suspended-sediment loads to the Nueces Estuary, south Texas, 1958-2010

16. Map showing model-estimated sediment yield by subwatershed for the runoff event of November 20-21, 2009, lower Nueces River watershed, south Texas

17. Map showing model-estimated sediment yield by subwatershed for the runoff event of September 7-8, 2010, lower Nueces River watershed, south Texas

18. Map showing model-estimated sediment yield by subwatershed for the runoff event of September 20-21, 2010, lower Nueces River watershed, south Texas

\section{Tables}

1. Annual suspended-sediment loads for the Nueces River near Mathis, Texas, 1942-58 and 1961-82

2. Streamflow and suspended-sediment loads for selected flow releases from Wesley E. Seale Dam on the Nueces River near Mathis, Texas, October 1964September 1971

3. Suspended-sediment sampling results, lower Nueces River watershed, south Texas, 2006-7, 2010

4. Data-collection sites providing data for the lower Nueces River watershed model, south Texas

5. Streamflow calibration and testing results for the lower Nueces River watershed model, south Texas

6. Measured and simulated streamflows, measured suspended-sediment particle size, and measured and simulated suspended-sediment concentrations and loads for selected sampling events at 08211000 Nueces River near Mathis, Texas, 2006-7, 2010 
7. Comparison of literature estimates and simulation results for sediment yields from selected land-cover and land-use types in the coastal area of south Texas and the lower Nueces River watershed

8. Measured and simulated streamflows, measured suspended-sediment particle size, and measured and simulated suspended-sediment concentrations and loads for selected suspended-sediment sampling events at 08211200 Nueces River at Bluntzer, Texas, 2006-7, 2010

9. Suspended-sediment calibration results for the Hydrological Simulation Program-FORTRAN model of the lower Nueces River watershed, south Texas, 2001-8

10. Measured and simulated streamflows, measured suspended-sediment particle size, and measured and simulated suspended-sediment concentrations and loads, for selected sampling events at 08211500 Nueces River near Calallen, Texas, 2006-7, 2010.

11. Summary of calibrated values for selected hydrologic parameters for the Hydrological Simulation Program-FORTRAN model of the lower Nueces River watershed, south Texas

12. Summary of calibrated values for selected sediment-related parameters for the Hydrological Simulation Program-FORTRAN model of the lower Nueces River watershed, south Texas

13. Sensitivity of simulated streamflow volumes and suspended-sediment loads to changes in selected process-related parameters for the lower Nueces River watershed model, south Texas ....

14. Estimated annual streamflows and suspended-sediment loads to the Nueces Estuary, south Texas, 1958-2010

15. Estimated annual suspended-sediment loads at selected stations, lower Nueces River watershed, south Texas, 1958-2010

16. Estimated annual streamflows and suspended-sediment loads, by sediment source, simulated by the Hydrological Simulation Program-FORTRAN model of the lower Nueces River watershed, south Texas, 1958-2010 


\section{Conversion Factors, Datum, and Water-Quality Abbreviation}

\section{Inch/Pound to SI}

\begin{tabular}{|c|c|c|}
\hline Multiply & By & To obtain \\
\hline \multicolumn{3}{|c|}{ Length } \\
\hline inch (in.) & 25.4 & millimeter $(\mathrm{mm})$ \\
\hline foot $(\mathrm{ft})$ & 0.3048 & meter $(\mathrm{m})$ \\
\hline mile (mi) & 1.609 & kilometer $(\mathrm{km})$ \\
\hline \multicolumn{3}{|c|}{ Area } \\
\hline acre & 0.4047 & hectare (ha) \\
\hline square mile $\left(\mathrm{mi}^{2}\right)$ & 2.590 & square kilometer $\left(\mathrm{km}^{2}\right)$ \\
\hline \multicolumn{3}{|c|}{ Volume } \\
\hline ounce, fluid (fl. oz) & 0.02957 & liter $(\mathrm{L})$ \\
\hline acre-foot (acre-ft) & 0.001233 & cubic hectometer $\left(\mathrm{hm}^{3}\right)$ \\
\hline \multicolumn{3}{|c|}{ Flow rate } \\
\hline inch per second & 0.0254 & meters per second $(\mathrm{m} / \mathrm{s})$ \\
\hline inch per hour & 0.0254 & meters per hour $(\mathrm{m} / \mathrm{h})$ \\
\hline acre-foot per year (acre-ft/yr) & 1,233 & cubic meter per year $\left(\mathrm{m}^{3} / \mathrm{yr}\right)$ \\
\hline acre-foot per years (acre-ft/yr) & 0.001233 & cubic hectometer per year $\left(\mathrm{hm}^{3} / \mathrm{yr}\right)$ \\
\hline cubic foot per second $\left(\mathrm{ft}^{3} / \mathrm{s}\right)$ & 0.02832 & cubic meter per second $\left(\mathrm{m}^{3} / \mathrm{s}\right)$ \\
\hline \multicolumn{3}{|c|}{ Mass } \\
\hline pound, avoirdupois (lb) & 0.4536 & kilogram (kg) \\
\hline ton, short $(2,000 \mathrm{lb})$ & 0.9072 & megagram (Mg) \\
\hline ton per day (ton/d) & 0.9072 & megagram (mg) \\
\hline ton per acre & 2,242 & kilogram per hectare $(\mathrm{kg} / \mathrm{ha})$ \\
\hline \multicolumn{3}{|c|}{ Pressure } \\
\hline pound per square foot $\left(\mathrm{lb} / \mathrm{ft}^{2}\right)$ & 0.04788 & kilopascal $(\mathrm{kPa})$ \\
\hline \multicolumn{3}{|c|}{ Hydraulic gradient } \\
\hline foot per mile (ft/mi) & 0.1894 & meter per kilometer $(\mathrm{m} / \mathrm{km})$ \\
\hline \multicolumn{3}{|c|}{ Yield } \\
\hline pound per acre (lb/acre) & 1.121 & kilogram per hectare kg/ha) \\
\hline
\end{tabular}

Temperature in degrees Fahrenheit $\left({ }^{\circ} \mathrm{F}\right)$ may be converted to degrees Celsius $\left({ }^{\circ} \mathrm{C}\right)$ as follows:

${ }^{\circ} \mathrm{C}=\left({ }^{\circ} \mathrm{F}-32\right) / 1.8$ 


\section{SI to Inch/Pound}

\begin{tabular}{lcl}
\hline \multicolumn{1}{c}{ Multiply } & By & \multicolumn{1}{c}{ To obtain } \\
\hline millimeter $(\mathrm{mm})$ & Length & \\
meter $(\mathrm{m})$ & 0.03937 & inch (in.) \\
& 3.281 & foot $(\mathrm{ft})$ \\
\hline milliliter $(\mathrm{mL})$ & Volume & \\
\hline & 0.03382 & ounce, fluid (fl. oz) \\
\hline kilogram $(\mathrm{kg})$ & Mass & \\
\hline & 2.205 & pound avoirdupois $(\mathrm{lb})$ \\
\hline gram per cubic centimeter $\left(\mathrm{g} / \mathrm{cm}^{3}\right)$ & Density & \\
\hline
\end{tabular}

Horizontal coordinate information is referenced to the North American Datum of 1983 (NAD 83). Vertical coordinate information is referenced to the National Geodetic Vertical Datum of 1929 (NGVD 29).

Concentrations of chemical constituents in water are given either in milligrams per liter ( $\mathrm{mg} / \mathrm{L})$ or micrograms per liter ( $\mu \mathrm{g} / \mathrm{L})$. 



\title{
Sources of Suspended-Sediment Loads in the Lower Nueces River Watershed, Downstream from Lake Corpus Christi to the Nueces Estuary, South Texas, 1958-2010
}

\author{
By Darwin J. Ockerman, Franklin T. Heitmuller, and Loren L. Wehmeyer
}

\section{Abstract}

The U.S. Geological Survey (USGS), in cooperation with the U.S. Army Corps of Engineers, Fort Worth District; City of Corpus Christi; Guadalupe-Blanco River Authority; San Antonio River Authority; and San Antonio Water System, developed, calibrated, and tested a Hydrological Simulation Program-FORTRAN (HSPF) watershed model to simulate streamflow and suspended-sediment concentrations and loads during 1958-2010 in the lower Nueces River watershed, downstream from Lake Corpus Christi to the Nueces Estuary in south Texas. Data available to simulate suspended-sediment concentrations and loads consisted of historical sediment data collected during 1942-82 in the study area and suspendedsediment concentration data collected periodically by the USGS during 2006-7 and 2010 at three USGS streamflowgaging stations (08211000 Nueces River near Mathis, Tex. [the Mathis gage], 08211200 Nueces River at Bluntzer, Tex. [the Bluntzer gage], and 08211500 Nueces River at Calallen, Tex. [the Calallen gage]), and at one ungaged location on a Nueces River tributary (USGS station 08211050 Bayou Creek at Farm Road 666 near Mathis, Tex.). The Mathis gage is downstream from Wesley E. Seale Dam, which was completed in 1958 to impound Lake Corpus Christi. Suspended-sediment data collected before and after completion of Wesley E. Seale Dam provide insights to the effects of the dam and reservoir on suspended-sediment loads transported by the lower Nueces River downstream from the dam to the Nueces Estuary.

Annual suspended-sediment loads at the Nueces River near the Mathis, Tex., gage were considerably lower for a given annual mean discharge after the dam was completed than before the dam was completed.

Most of the suspended sediment transported by the Nueces River downstream from Wesley E. Seale Dam occurred during high-flow releases from the dam or during floods. During October 1964-September 1971, about 536,000 tons of suspended sediment were transported by the Nueces River past the Mathis gage. Of this amount, about 473,000 tons, or about 88 percent, were transported by large runoff events (mean streamflow exceeding 1,000 cubic feet per second).
To develop the watershed model to simulate suspendedsediment concentrations and loads in the lower Nueces River watershed during 1958-2010, streamflow simulations were calibrated and tested with available data for 2001-10 from the Bluntzer and Calallen gages. Streamflow data for the Nueces River obtained from the Mathis gage were used as input to the model at the upstream boundary of the model. Simulated streamflow volumes for the Bluntzer and Calallen gages showed good agreement with measured streamflow volumes. For 2001-10, simulated streamflow at the Calallen gage was within 3 percent of measured streamflow.

The HSPF model was calibrated to simulate suspended sediment using suspended-sediment data collected at the Mathis, Bluntzer, and Calallen gages during 2006-7. Model simulated suspended-sediment loads at the Calallen gage were within 5 percent of loads that were estimated, by regression, from suspended-sediment sample analysis and measured streamflow. The calibrated watershed model was used to estimate streamflow and suspended-sediment loads for 1958-2010, including loads transported to the Nueces Estuary. During 1958-2010, on average, an estimated 288 tons per day (tons/d) of suspended sediment were delivered to the lower Nueces River; an estimated 278 tons/d were delivered to the estuary. The annual suspended-sediment load was highly variable, depending on the occurrence of runoff events and high streamflows. During 1958-2010, the annual total sediment loads to the estuary varied from an estimated 3.8 to 2,490 tons/d. On average, 113 tons/d, or about 39 percent of the estimated annual suspended-sediment contribution, originated from cropland in the study watershed. Releases from Lake Corpus Christi delivered an estimated 94 tons/d of suspended sediment or about 33 percent of the 288 tons/d estimated to have been delivered to the lower Nueces River. Erosion of stream-channel bed and banks accounted for 44 tons/d or about 15 percent of the estimated total suspendedsediment load. All other land categories, except cropland, accounted for an estimated 36 tons/d, or about 12 percent of the total. An estimated 10 tons/d of suspended sediment or about 3 percent of the suspended-sediment load delivered to the lower Nueces River were removed by water withdrawals before reaching the Nueces Estuary. 
During 2010, additional suspended-sediment data were collected during selected runoff events to provide new data for model testing and to help better understand the sources of suspended-sediment loads. The model was updated and used to estimate and compare sediment yields from each of 64 subwatersheds comprising the lower Nueces River watershed study area for three selected runoff events: November 20-21, 2009, September 7- 8, 2010, and September 20-21, 2010. These three runoff events were characterized by heavy rainfall centered near the study area and during which minimal streamflow and suspended-sediment load entered the lower Nueces River upstream from Wesley E. Seale Dam. During all three runoff events, model simulations showed that the greatest sediment yields originated from the subwatersheds, which were largely cropland. In particular, the Bayou Creek subwatersheds were major contributors of suspendedsediment load to the lower Nueces River during the selected runoff events. During the November 2009 runoff event, high suspended-sediment concentrations in the Nueces River water withdrawn for the City of Corpus Christi public-water supply caused problems during the water-treatment process, resulting in failure to meet State water-treatment standards for turbidity in drinking water. Model simulations of the November 2009 runoff event showed that the Bayou Creek subwatersheds were the primary source of suspended-sediment loads during that runoff event.

\section{Introduction}

The Nueces River extends approximately 315 miles (mi) from its headwaters in the southern Edwards Plateau in south Texas to Nueces Bay near Corpus Christi, Tex., and has a drainage area of approximately 16,700 square miles $\left(\mathrm{mi}^{2}\right)$ (fig. 1). The river exits the Edwards Plateau near Uvalde, Tex., and enters the South Texas Plains, also referred to as the South Texas Brush Country (Texas Parks and Wildlife Department, 2013), where the majority of its length and drainage area are located. The Frio River, a major tributary, joins the Nueces River near Three Rivers, Tex. Major impoundments in the Nueces River watershed in the South Texas Plains include Upper Lake (also known as Upper Nueces Reservoir), formed in 1948 by Upper Dam; Choke Canyon Reservoir, formed in 1982 by Choke Canyon Dam (on the Frio River); and Lake Corpus Christi, impounded by Mathis Dam in 1935 (surface area 5,493 acres, conservation storage volume 43,800 acre-feet [acre-ft]) (Texas Water Development Board, 2002) and impounded since 1958 by Wesley E. Seale Dam (surface area 19,251 acres, conservation storage volume 257,260 acre-ft) (City of Corpus Christi, 2010). Downstream from Wesley E. Seale Dam (fig. 2), the Nueces River flows about $50 \mathrm{mi}$ through an alluvial valley to the Nueces Bay.

The Nueces Estuary (fig. 2) consists of two areas of nearly equal size, Nueces Bay and the Nueces River Delta. Nueces Bay is a shallow, $27 \mathrm{mi}^{2}$ secondary bay of Corpus
Christi Bay. Nueces Bay has a mean depth of about 2.5 feet (ft) and a volume of about 40,000 acre-ft. Bottom sediments in Nueces Bay are deposited mostly by the Nueces River (Yeager and others, 2006). The Nueces River Delta in southern San Patricio County is a $28-\mathrm{mi}^{2}$ area of vegetated salt and brackish marshes, land subject to inundation from river or tidal flooding, and open water formed where the Nueces River flows into Nueces Bay (fig. 2). Currently (2013), the Nueces River channel is located along the southern margins of the delta. The distributary network includes a manmade overflow channel in the northwestern part of the delta that connects the Nueces River to Rincon Bayou (U.S. Bureau of Reclamation, 2000; Ockerman, 2001).

In November 2005, during a resource agency meeting in San Antonio, Tex., the U.S. Army Corps of Engineers (USACE) highlighted 12 ecological problems in the Nueces River watershed. One of these was a "loss of sediment loading and nutrient loads to estuaries" (Marcia Hackett, U.S. Army Corps of Engineers, Fort Worth District, written commun., 2005). A number of the other ecological problems were directly related, including a reduction of overbank flows downstream from reservoirs and a decrease in freshwater inflows to the Nueces Estuary. The reduction in sediment loads to the Nueces Estuary is the result of sedimentation in large impoundments, notably Lake Corpus Christi (Leibbrand, 1987). Downstream from the reservoirs, ecological problems caused by sedimentation impoundment are expected to include river channel incision (Williams and Wolman, 1984; Salant and others, 2006), channel-bed armoring (Williams and Wolman, 1984; Vericat and others, 2006), and deltaic and shoreline erosion (Jaffe and others, 1998; Fan and others, 2006; Yang and others, 2006). Reductions in the extent of marshland and vegetated areas in the Nueces River Delta occurred following the initial impoundment of Lake Corpus Christi (Morton and Paine 1984; White and Calnan, 1991). The decreased sediment loads of the Nueces River, combined with relative sea-level rise and subsidence, are responsible for deltaic erosion and the conversion of wetland habitat to open water and shallow flats (Day and others, 1995; White and others, 2002; Yeager and others, 2006).

The USACE, Fort Worth District, began a study in 2002 to identify opportunities for flood-damage reduction, ecosystem restoration, and implementation of multipurpose projects in the Nueces River Basin (U.S. Army Corps of Engineers, 2009). The purpose of the USACE study was to participate with other (Federal and non-Federal) sponsor agencies to identify and conduct detailed studies of waterresource problems in the Nueces River Basin (fig. 1 ), including documenting existing hydrologic, engineering, and environmental conditions of the study area. One of the specific feasibility investigations outlined in the USACE study related to defining the existing conditions and opportunities for ecosystem restoration in the Nueces Estuary, namely, an investigation of the current conditions of suspended-sediment concentrations and loads delivered by the Nueces River to the estuary. As part of this feasibility study, the U.S. Geological 


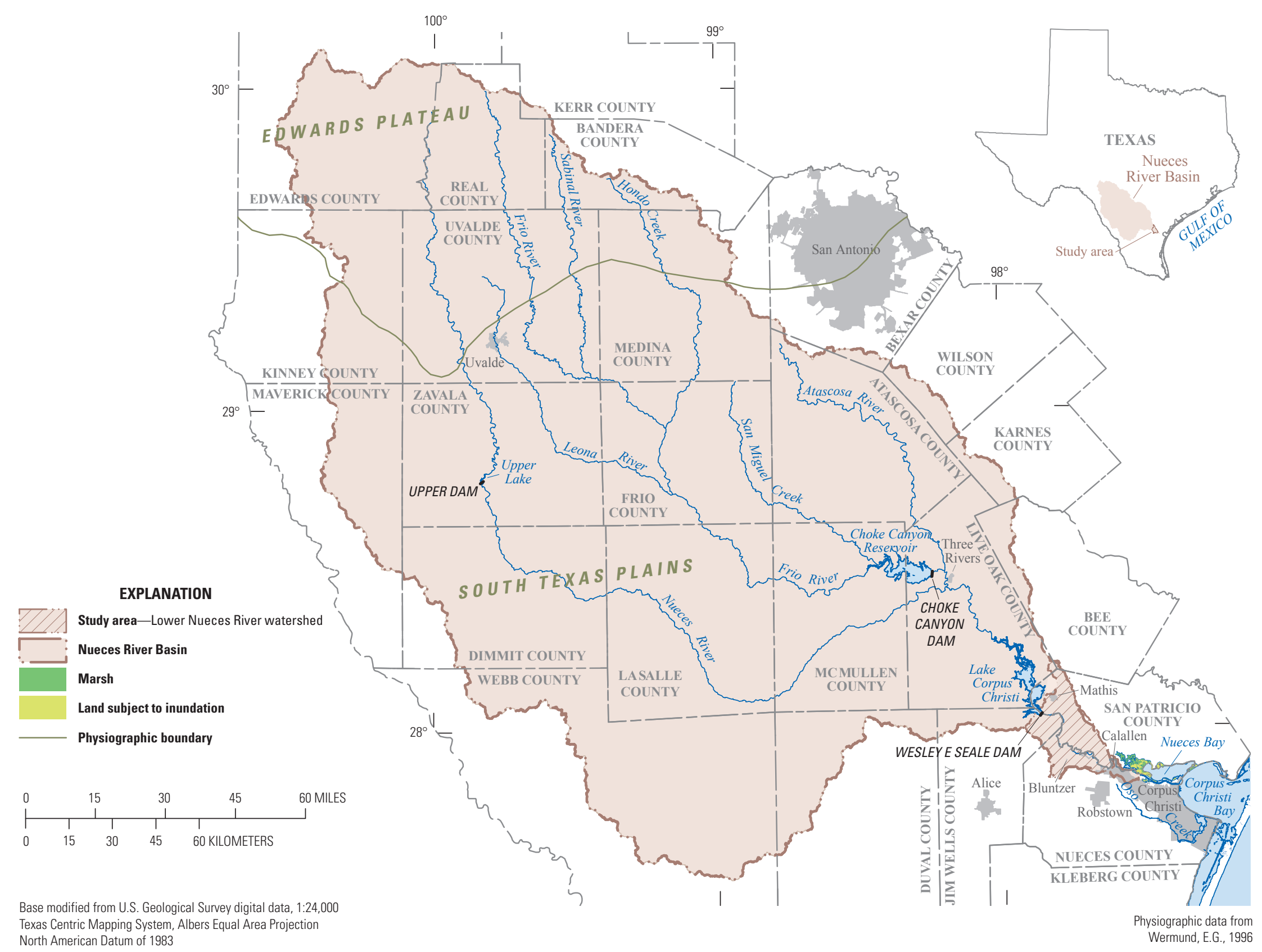

Figure 1. Location of Nueces River Basin, including lower Nueces River study area, south Texas. 


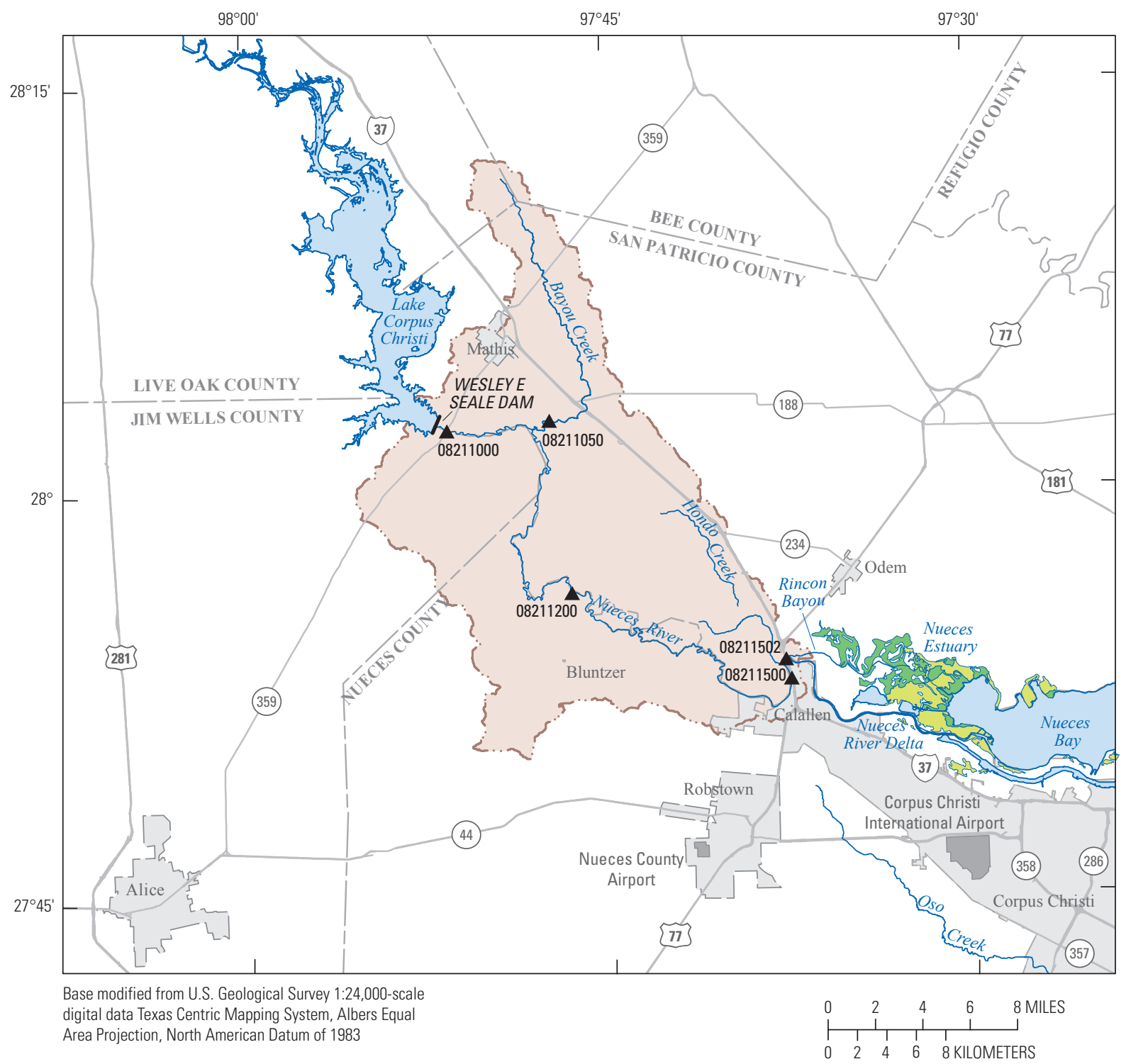

EXPLANATION

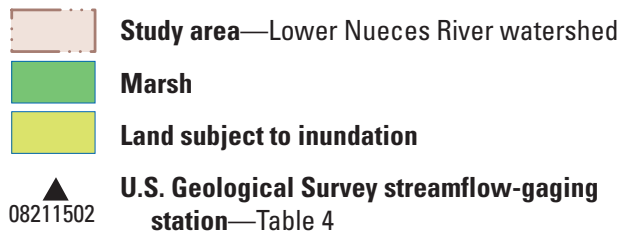

Figure 2. Location of lower Nueces River watershed, south Texas.

Survey (USGS), in cooperation with the USACE Fort Worth District, City of Corpus Christi, Guadalupe-Blanco River Authority, San Antonio River Authority, and San Antonio Water System, developed, calibrated, and tested a watershed model of the lower Nueces River watershed to simulate existing hydrologic conditions and suspendedsediment concentrations and loads to the Nueces Estuary. The USGS study simulated streamflow and suspended-sediment concentrations and loads during 1958-2008 in the lower Nueces River watershed, downstream from Lake Corpus Christi to the Nueces Estuary in south Texas. In 2010, a USGS Scientific Investigations Report (Ockerman and Heitmuller, 2010) was published documenting data collection, model calibration, and model simulation results of the study.

In November 2009, the City of Corpus Christi failed to meet State water-treatment standards for turbidity in drinking 
water because of high concentrations of suspended sediment in raw water withdrawn from the Nueces River near Calallen (Corpus Christi Caller Times, 2009). At the time, the Nueces River was experiencing runoff caused by heavy rains. During this event, releases from Lake Corpus Christi were minimal and runoff originated almost entirely from the subwatersheds downstream from Lake Corpus Christi and the Wesley E. Seale Dam. Because of this problem, the City of Corpus Christi expressed interest in gaining a better understanding of sources (locations, land uses, land-management practices) of sediment and possible methods for reducing Nueces River suspended-sediment concentrations during periods of runoff. Accordingly, the USGS, in cooperation with the USACE; City of Corpus Christi; Guadalupe-Blanco River Authority; San Antonio River Authority; and the San Antonio Water System, completed a study using an updated version of a previously developed watershed model (Ockerman and Heitmuller, 2010) to characterize sources of suspended sediment during a November 2009 runoff event and during selected runoff events in 2010 and characterized sediment yields from selected subwatersheds in the lower Nueces River watershed.

\section{Purpose and Scope}

The purpose of this report is to estimate suspendedsediment concentrations and loads (mass of suspended sediment transported by streamflow over a period of time) in the lower Nueces River watershed downstream from Lake Corpus Christi to the Nueces Estuary during 19582010, characterize the sources of those loads, and estimate suspended-sediment yields by subwatershed for selected runoff events during 2009-10. To accomplish this, previous suspended-sediment data and studies for the study area were reviewed, and the simulation period (1958-2008) used by Ockerman and Heitmuller (2010) to develop a model of the Nueces watershed was extended to simulate the period $1958-2010$ by using additional data collected during 2010 . For selected runoff events of 2009-10, the model also was used to estimate sediment yields, by subwatershed, to help understand areas of the watershed that contribute high sediment loads during runoff events. Limitations of model-simulated estimates of sediment loads are described. The wording and presentation of material in this report are based on a previous USGS report (Ockerman and Heitmuller, 2010); the contents of each section are modified from this previous report.

\section{Description of the Lower Nueces River Watershed}

The lower Nueces River study area comprises about $216 \mathrm{mi}^{2}$ of the nontidal part of the Nueces River watershed, from the outlet of Wesley E. Seale Dam near Mathis (fig. 2) to the tidal reach of the river that flows into the Nueces Estuary. The study area encompasses parts of Bee, Jim Wells, Live Oak, Nueces, and San Patricio Counties in south Texas.
The largest town in the study area is Mathis, Tex., which had a population of 4,942 in 2010 (U.S. Census Bureau, 2013).

The study area has a subtropical, subhumid climate characterized by hot summers and mild winters (Larkin and Bomar, 1983). The average monthly low temperatures range from 46.2 degrees Fahrenheit $\left({ }^{\circ} \mathrm{F}\right)$ in January to $74.5^{\circ} \mathrm{F}$ in August; average daily high temperatures range from $66.0^{\circ} \mathrm{F}$ in January to $93.4^{\circ} \mathrm{F}$ in August (National Climatic Data Center, 2012). The average annual rainfall (1971-2000) in the study area is about 32.6 inches (32.2 inches at Mathis National Weather Service [NWS] station, cooperative observer identification [COOP ID] 415661 and 32.9 inches at Robstown NWS station, COOP ID 417677). Daily rainfall greater than 0.01 inch occurs, on average, 70 days per year (National Climatic Data Center, 2012); daily rainfall equal to or greater than 1.0 inch occurs, on average, every 39 days (Asquith and Roussel, 2003). Although most rainfall occurs in spring, early summer, and fall, amounts greater than about 1.0 inch can occur anytime during the year (Larkin and Bomar, 1983).

Most land use is rangeland and cropland. Elevation in the lower Nueces River watershed ranges from about 3 to $230 \mathrm{ft}$ above National Geodetic Vertical Datum of 1929 (NGVD 29). (U.S. Geological Survey, 2013b). Land slopes are generally low, mostly less than 5 percent. Overall, the stream-channel slope of the lower Nueces River is about 1 foot per mile $(\mathrm{ft} / \mathrm{mi}$ ) over the $38 \mathrm{mi}$ from the outlet of Wesley E. Seale Dam to the river crossing at Interstate Highway 37, north of Corpus Christi (fig. 2).

\section{Suspended-Sediment Concentrations and Loads of the Lower Nueces River}

Characterizing suspended-sediment concentrations and loads in the lower Nueces River included the following major steps: (1) a review of the available suspendedsediment concentration and load data and studies, including a compilation of historical estimates of suspended-sediment loads; (2) collection of suspended-sediment data during 2010 (to supplement the 2006-7 data collection in the earlier phase of the study); (3) development and calibration of a watershed model to simulate suspended-sediment concentrations and loads in the lower Nueces River watershed; (4) estimation of annual suspended-sediment loads to the Nueces Estuary for 1958-2010, including a characterization of sources of suspended-sediment loads to the Nueces River during selected runoff events of 2009-10.

\section{Review of Historical Suspended-Sediment Data and Studies in the Lower Nueces River}

Various studies have investigated the problems associated with the reduction in sediment loads to the Nueces Estuary 
Sources of Suspended-Sediment Loads in the Lower Nueces River Watershed, Downstream from Lake Corpus Christi

and the associated loss of wetland habitats in the Nueces River Delta. Morton and Paine (1984) used aerial photographs to show that the propagation of deltaic wetlands in the Nueces River Delta ceased sometime between 1930 and 1959. These findings were substantiated by White and Calnan (1990), who also showed an additional decrease in net vegetated areas by 1979 . As further support to the importance of sediment transport in maintaining the Nueces River Delta, Leibbrand (1987) showed that almost all sediment entering Lake Corpus Christi between 1972 and 1985 was trapped. Recent studies showed that loss of wetlands in the Nueces Estuary not only was the result of upstream impoundments but also was influenced by gradual subsidence of the delta (White and others, 2002). As a consequence of these two factors, White and others (2002) also predicted that wetland areas would continue to decrease in the Nueces River Delta. Finally, Yeager and others (2006) showed that sediment in Nueces Bay is supplied mostly by the river rather than by marine sources (transport from the Gulf of Mexico by wind or tidal currents), supporting claims that a reduction of suspended-sediment inflow from the Nueces River will contribute to loss of Nueces Estuary wetland habitat.

In 1924, the Texas Board of Water Engineers (whose name and functions were subsequently changed several times by the Texas Legislature and whose functions, unrelated to water rights, were transferred to the Texas Water Development Board [TWDB] in 1965) initiated a program to evaluate the economic life of reservoirs, which included monitoring suspended-sediment loads in selected Texas rivers (Stout and others, 1961; Mirabal, 1974). During the program, the USGS (in 1942) established one site in the lower Nueces River study area (fig. 2), USGS streamflow-gaging station 08211000 Nueces River near Mathis, Tex. (hereinafter the Mathis gage). Suspended-sediment concentration samples were collected on a daily basis at this site by TWDB and its predecessor agencies; monthly and annual suspendedsediment concentration data and sediment loads (using streamflow data from the Mathis gage) were computed until 1982 and published by various authors, including Stout and others (1961), Cook (1967, 1970), Mirabal (1974), Dougherty (1979), and Quincy (1988).

Records for June 1958-June 1961 were invalid (Adey and Cook, 1964) and were not used for interpretation in this report. Suspended-sediment samples were collected during 1942-82 using an 8-ounce (236.3-milliliter) narrowneck bottle, which was held in a 10-pound (4.54-kilogram) torpedo-shaped sampler frame positioned approximately $1 \mathrm{ft}$ ( 0.3 meter) below the water surface. Samples were collected daily or throughout the day if the stage changed considerably. Samples were collected at one-sixth, one-half, and five-sixths of the water-surface width using a sampling device called the "Texas sampler" (Stout and others, 1961; Welborn, 1967). To account for increasing suspended-sediment concentrations with depth, the measured percentage of suspended sediment by weight was multiplied by a correction factor of 1.102 to obtain the mean percentage of suspended sediment in the vertical profile (Farris, 1933). Suspended-sediment loads were computed with the assumptions that 1 acre-ft of streamflow weighed 1,361.25 tons and 1 acre-ft of sediment weighed 1,524.60 tons (Stout and others, 1961). Since 1982, most sediment data have been collected as part of relatively shortterm studies for selected river reaches (for example, Phillips and others, 2005; Yeager and others, 2005).

To verify the accuracy of the suspended-sediment sampling method described in the previous paragraph, referred to hereinafter as the "Texas sampler method," Welborn (1967) compared the results of samples collected from various Texas streams by the Texas sampler method with results of concurrent samples collected by a depth-integrated method (Edwards and Glysson, 1999). Correlations between the two methods for sand-bed rivers in east Texas were poor, but were very good (differing by 15 percent or less) for mixed-bed and gravel-bed rivers. The lower Nueces River is a mixedsand and gravel-bed channel; therefore, suspended-sediment data collected using the Texas sampler method were deemed reasonably accurate for computation of historical loads.

Suspended-sediment data collected before and after completion of Wesley E. Seale Dam provide insights to the effects of the dam and reservoir on suspended-sediment loads transported by the lower Nueces River downstream from the dam to the Nueces Bay. Suspended-sediment loads (fig. 3; table 1) measured by TWDB and its predecessor agencies at the Mathis gage decreased appreciably in the years after completion of Wesley E. Seale Dam in 1958. During 9 of the 16 years before completion of the dam, annual suspendedsediment loads exceeded 100,000 tons. The maximum annual suspended-sediment load for the period of record was 561,739 tons in 1957; an amount that likely was larger compared with loads for all previous years because of the erosion of sediment during construction of Wesley E. Seale Dam immediately upstream from the suspended-sediment sampling site. In the 21 years following completion of the dam, for which reliable suspended-sediment data were available (1962-82), more than 100,000 tons of suspended sediment were transported in only 2 years -1967 and 1971 . These 2 years were characterized by relatively high annual mean streamflows at the Mathis gage - 2,167 and 2,140 cubic feet per second ( $\left.\mathrm{ft}^{3} / \mathrm{s}\right)$ in 1967 and 1971, respectively. During 1962-82, annual suspendedsediment loads were considerably lower, for a given annual mean discharge, than in the years before the dam was completed (fig. 3; table 1). The relation between annual suspended-sediment loads and annual mean streamflow before and after completion of Wesley E. Seale Dam is shown on figure 3 . As an indication of the sediment-retention capacity of the dam for comparable annual mean discharges, annual suspended-sediment loads after completion of the dam have been consistently lower compared with annual suspendedsediment loads before completion of the dam (fig. 3 ).

Most of the suspended sediment transported by the Nueces River downstream from Wesley E. Seale Dam occurred during high-flow releases from the dam or during floods. During October 1964-September 1971, about 


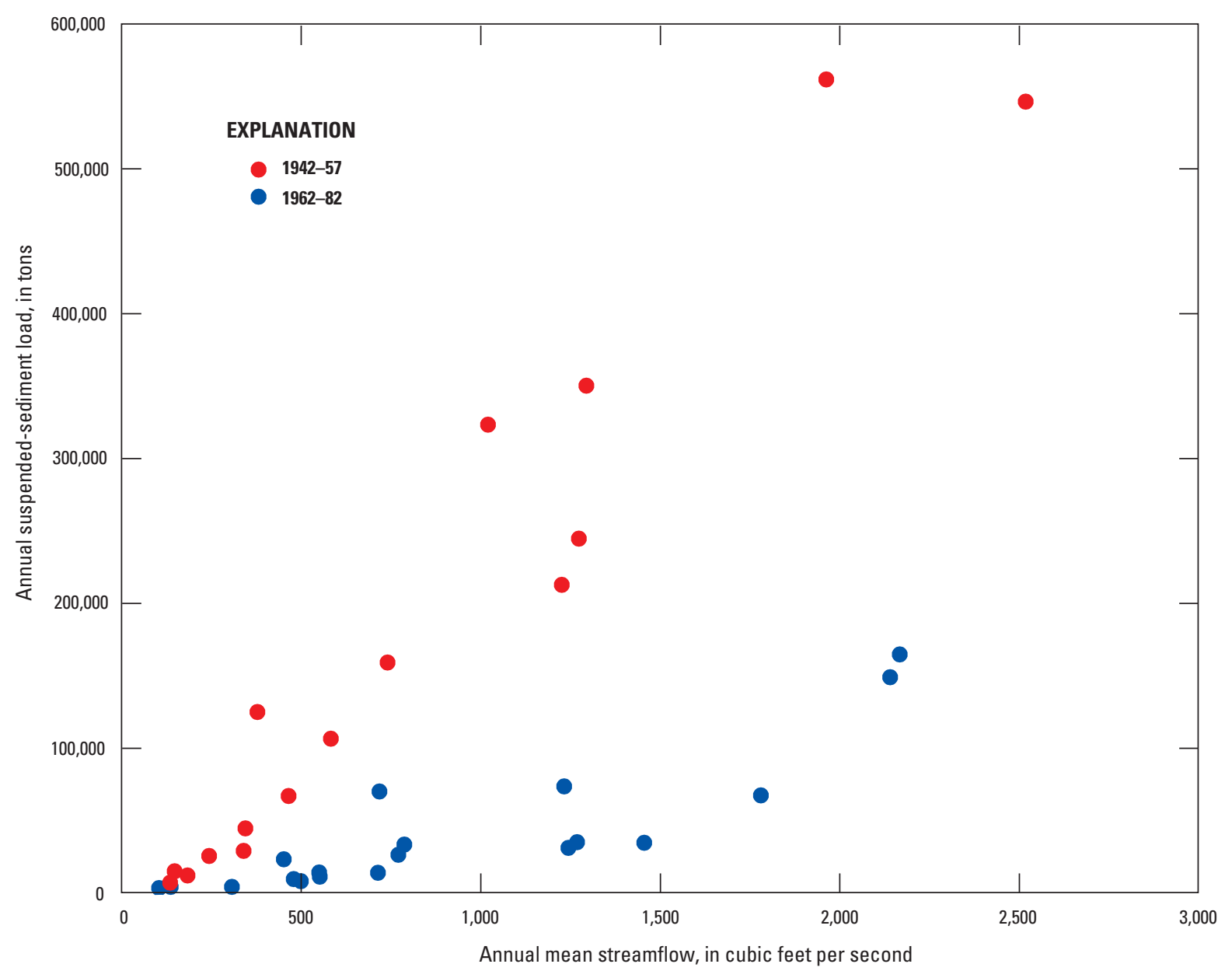

Figure 3. Annual suspended-sediment loads for the Nueces River near Mathis, Texas, 1942-57 and 1962-82.

536,000 tons of suspended sediment were transported by the Nueces River near Mathis (table 1). Of this amount, about 473,000 tons (table 2), or about 88 percent, were transported by large runoff events (mean streamflow exceeding 1,000 $\mathrm{ft}^{3} / \mathrm{s}$ ). Furthermore, the suspended-sediment transport rate increases with higher magnitude flows (fig. 3). The largest flow event listed in table 2 (September 21-October 11, 1967) transported 186,302 tons of suspended sediment (an average of 8,872 tons per day [tons/d] of suspended sediment).

\section{Recent (2006-7 and 2010) Suspended-Sediment Sampling}

In addition to historical suspended-sediment data collected daily by the TWDB and its predecessor agencies at the Mathis gage during 1942-82, the USGS periodically collected suspended-sediment samples during 2006-7 as part of the earlier study (Ockerman and Heitmuller, 2010) at the Mathis gage, station 08211200 Nueces River at Bluntzer, Tex. (hereinafter the Bluntzer gage), and station 08211500 Nueces River at Calallen, Tex. (hereinafter the Calallen gage) (fig. 2). Whereas the historical suspended-sediment data-collection program typically involved daily sample collection to compute long-term sediment loads, 2006-7 suspended-sediment samples represent data only for selected streamflow and sediment-load conditions. Eight suspended-sediment samples were collected at the Mathis gage, 11 at the Bluntzer gage, and 10 at the Calallen gage.

The USGS collected and analyzed suspended-sediment samples during two runoff events in September 2010 at the three streamflow-gaging stations on the Nueces River. One suspended-sediment sample was collected at both the Mathis and Calallen gages, and three samples were collected at the Bluntzer gage. Two samples also were collected at a miscellaneous discharge and sediment sampling site on a Nueces River tributary-USGS station 08211050 Bayou Creek at Farm Road 666 near Mathis, Tex. (hereinafter the Bayou Creek site). 
Table 1. Annual suspended-sediment loads for the Nueces River near Mathis, Texas, 1942-58 and 1961-82 (from Stout and others, 1961; Adey and Cook, 1964; Cook, 1967, 1970; Mirabal, 1974).

\begin{tabular}{|c|c|c|c|c|}
\hline $\begin{array}{l}\text { Hydrologic } \\
\text { year }^{1,2}\end{array}$ & $\begin{array}{l}\text { Number of days measured } \\
\text { during hydrologic year }\end{array}$ & $\begin{array}{l}\text { Annual suspended- } \\
\text { sediment load } \\
\text { (tons) }\end{array}$ & $\begin{array}{l}\text { Annual mean suspended- } \\
\text { sediment load } \\
\text { (tons per day) }\end{array}$ & $\begin{array}{l}\text { Annual mean streamflow } \\
\text { (cubic feet per second) }\end{array}$ \\
\hline 1942 & 241 & 546,504 & 2,268 & 2,517 \\
\hline 1943 & 365 & 44,790 & 123 & 345 \\
\hline 1944 & 366 & 323,550 & 884 & 1,020 \\
\hline 1945 & 365 & 125,070 & 343 & 378 \\
\hline 1946 & 365 & 350,430 & 960 & 1,294 \\
\hline 1947 & 365 & 244,730 & 670 & 1,273 \\
\hline 1948 & 366 & 15,170 & 41 & 148 \\
\hline 1949 & 365 & 212,770 & 583 & 1,226 \\
\hline 1950 & 365 & 29,160 & 80 & 340 \\
\hline 1951 & 365 & 106,740 & 292 & 583 \\
\hline 1952 & 366 & 25,670 & 70 & 244 \\
\hline 1953 & 365 & 159,200 & 436 & 741 \\
\hline 1954 & 365 & 67,020 & 184 & 465 \\
\hline 1955 & 365 & 7,269 & 20 & 135 \\
\hline 1956 & 366 & 12,165 & 33 & 184 \\
\hline 1957 & 365 & 561,739 & 1,539 & 1,962 \\
\hline 1958 & 243 & 395,791 & 1,629 & 2,179 \\
\hline 1961 & 92 & 2,088 & 23 & 373 \\
\hline 1962 & 365 & 2,845 & 8 & 111 \\
\hline 1963 & 365 & 2,769 & 8 & 110 \\
\hline 1964 & 366 & 3,445 & 9 & 104 \\
\hline 1965 & 365 & 33,642 & 92 & 787 \\
\hline 1966 & 365 & 23,400 & 64 & 452 \\
\hline 1967 & 365 & 177,600 & 48 & 2,167 \\
\hline 1968 & 366 & 73,640 & 201 & 1,232 \\
\hline 1969 & 365 & 4,810 & 13 & 136 \\
\hline 1970 & 365 & 70,290 & 193 & 718 \\
\hline 1971 & 365 & 149,100 & 408 & 2,140 \\
\hline 1972 & 366 & 67,530 & 185 & 1,780 \\
\hline 1973 & 365 & 14,030 & 38 & 714 \\
\hline 1974 & 365 & 31,370 & 86 & 1,244 \\
\hline 1975 & 365 & 11,450 & 31 & 552 \\
\hline 1976 & 366 & 12,460 & 34 & 550 \\
\hline 1977 & 365 & 34,830 & 95 & 1,455 \\
\hline 1978 & 365 & 4,280 & 12 & 307 \\
\hline 1979 & 365 & 8,210 & 22 & 499 \\
\hline 1980 & 366 & 26,560 & 73 & 771 \\
\hline 1981 & 365 & 35,190 & 96 & 1,268 \\
\hline 1982 & 365 & 9,790 & 27 & 479 \\
\hline
\end{tabular}

${ }^{1}$ A hydrologic year begins October 1 of previous calendar year and ends September 30 of reported year.

${ }^{2}$ Data for June 1958-June 1961 are invalid (Adey and Cook, 1964) and are not included. 
Table 2. Streamflow and suspended-sediment loads for selected flow releases from Wesley E. Seale Dam on the Nueces River near Mathis, Texas, October 1964-September 1971 (from Cook, 1970; Mirabal, 1974).

\begin{tabular}{|c|c|c|c|}
\hline Event & $\begin{array}{l}\text { Mean } \\
\text { stream- } \\
\text { flow } \\
\text { (cubic } \\
\text { feet per } \\
\text { second) }\end{array}$ & $\begin{array}{l}\text { Suspended- } \\
\text { sediment } \\
\text { load } \\
\text { (tons) }\end{array}$ & $\begin{array}{c}\text { Mean } \\
\text { suspended- } \\
\text { sediment } \\
\text { load } \\
\text { (tons per } \\
\text { day) }\end{array}$ \\
\hline October 5-16, 1964 & 7,425 & 7,506 & 682 \\
\hline February 24-March 11, 1965 & 2,727 & 3,939 & 246 \\
\hline May 20-June 11, 1965 & 4,465 & 15,541 & 676 \\
\hline May 2-June 10, 1966 & 2,980 & 18,653 & 466 \\
\hline September 21-October 11, 1967 & 35,129 & 186,302 & 8,872 \\
\hline October 16-30, 1967 & 1,545 & 4,318 & 288 \\
\hline January 21-February 11, 1968 & 5,492 & 14,802 & 673 \\
\hline May 8-June 5, 1968 & 4,970 & 15,806 & 545 \\
\hline July $12-16,1968$ & 2,544 & 4,909 & 982 \\
\hline October 19-November 19, 1969 & 1,968 & 5,438 & 170 \\
\hline May 25-June 14, 1970 & 5,543 & 50,447 & 2,402 \\
\hline July 8-18, 1971 & 9,894 & 17,480 & 1,589 \\
\hline August 8-September 6, 1971 & 11,006 & 74,537 & 2,485 \\
\hline September 10-30, 1971 & 14,432 & 53,578 & 2,551 \\
\hline
\end{tabular}

The samples collected during 2010 provided additional suspended-sediment concentration and load information to compare with results of model simulations that were extended beyond the original calibration period of the model (2001-8) (Ockerman and Heitmuller, 2010). The inclusion of samples from the Bayou Creek site provided data for a relatively large part of the study area that is primarily cropland.

Using standard USGS protocols and procedures (U.S. Geological Survey, 2006), an isokinetic sampler was used to collect suspended-sediment samples in 2006-7, and 2010. Davis $(2005$, p. 1) noted that "an isokinetic sampler collects a water-sediment sample from the stream at a rate such that the velocity in the intake nozzle is equal to the incident stream velocity at the nozzle entrance. The water-sediment sample collected is therefore representative of the sediment load at that point (in the stream)."

Samples were collected at 5 or more (usually 10) equally spaced intervals across the stream channel and were depth integrated by lowering and raising the sampler through the water column at a constant rate. The samples from each equal-width segment were then combined into a single composite sample for analysis. A composite water-sediment sample is horizontally and vertically averaged throughout the stream cross section and is assumed to represent the average streamflow-weighted suspended-sediment concentration (Edwards and Glysson, 1999; U.S. Geological Survey, 2006).

Suspended-sediment samples were collected by wading when streamflow conditions permitted. During high-flow conditions, when wading was not possible, samples were collected from a bridge or by boat. Suspended-sediment samples collected by the USGS were analyzed by the USGS sediment laboratory in Iowa City, Iowa. Samples were analyzed for suspended-sediment concentration and sandseparation analysis (Guy, 1969). Sand-separation analysis provides the percentage of sediment, by weight, that is either smaller or larger than 0.0625 millimeter. Particle sizes smaller than 0.0625 millimeter are defined as silt and clay; particle sizes 0.0625 millimeter or larger are defined as sand (Guy, 1969).

Each suspended-sediment sample collected by the USGS was associated with a streamflow value. Streamflow data were usually obtained from the stage-discharge rating curve at the streamflow-gaging station where suspended-sediment samples were collected (Rantz and others, 1982). For some high-flow conditions, streamflow measurements were made when the suspended-sediment samples were collected. The availability of streamflow data and suspended-sediment concentration data allowed computation of suspended-sediment discharge, or load, according to equation 1 :

$$
L_{s}=Q \times C_{s} \times k_{s}
$$

where

$$
\begin{aligned}
& L_{s} \quad \text { is the instantaneous suspended-sediment load, } \\
& \text { in tons per day; } \\
& \begin{array}{c}
C_{s} \quad \text { is the streamflow, in cubic feet per second; } \\
\text { is the suspended-sediment concentration, in } \\
\text { milligrams per liter; and }
\end{array} \\
& k_{s} \quad \text { is a conversion factor of } 0.0027 \text {, which results } \\
& \text { in a sediment load in tons per day, given } \\
& \text { streamflow in cubic feet per second and } \\
& \text { suspended-sediment concentration in } \\
& \text { milligrams per liter (Porterfield, 1972, } \\
& \text { p. 46-47). }
\end{aligned}
$$

Quality control (QC) samples, designed to ensure the integrity of the suspended-sediment data analyzed in this report, represented 10 percent of the field samples collected. QC samples consisted of replicate samples that were collected to evaluate bias and variability of data that might have resulted from sample collection, processing, and laboratory analysis. Sequential replicate samples were collected immediately after the primary samples were collected, at the same location and according to the same protocols (U.S. Geological Survey, 2006, section 4.3.2.B).

The results of the suspended-sediment sampling and analyses (measured concentrations and particle-size 
distributions) are shown in table 3 . A total of 40 samples, including 4 QC samples were collected from the sampling locations. Samples were collected for a relatively wide range of streamflow conditions (low flows, high flows, releases from Wesley E. Seale Dam, and runoff events) at all of the sampling locations. The resulting measured suspended-sediment concentrations and loads also exhibited a relatively wide range of values, thus providing a varied range of streamflow and sediment data for model calibration.

By calculating relative percent differences, it was determined that sample concentrations of two replicate samples collected at the Bluntzer gage (May 17, 2006, and July 20, 2006, samples) were within 10 percent of the environmental sample concentrations. Sample concentrations of two samples collected at the Mathis gage varied from the concentrations of the respective environmental samples by 19 percent (May 17, 2006, samples) and 35 percent (July 20, 2006, samples) (table 3). An explanation for the larger difference in concentrations between replicate and primary samples at the Mathis gage, compared with the replicate results at the Bluntzer gage, is suspended-sediment concentrations were lower at the Mathis gage, and relatively small difference in concentrations can result in relatively large percentage differences. Also, large sampling errors are often observed in routine replicate samples for suspended sediment that indicate significant temporal variability for sediment can exist over relatively short timeframes (Kelly, and others, 2001).

\section{Simulation of Streamflow and Suspended-Sediment Concentrations and Loads of the Lower Nueces River Watershed}

Historical suspended-sediment loads during 1942-82 are available for the Nueces River near Mathis (at the Mathis gage), and suspended-sediment concentrations and loads downstream from the Mathis gage were modeled by Ockerman and Heitmuller (2010). To better understand suspended-sediment conditions in the lower Nueces River, estimates of the amount of suspended sediment transported to the Nueces Estuary were prepared using an updated version of the watershed model developed by Ockerman and Heitmuller (2010) to simulate streamflow and suspended-sediment loads in the lower Nueces River.

Streamflow and suspended-sediment concentrations and loads were simulated with the Hydrological Simulation Program-FORTRAN (HSPF) (Bicknell and others, 2001). HSPF was selected for the study watershed because it is one of the more comprehensive watershed models available, can simulate a variety of stream and watershed conditions with reasonable accuracy, and enables flexibility in adjusting the model to simulate alternative conditions or scenarios (Donigian and others, 1995). To simulate the hydrologic and sediment processes that occur in a watershed, different data sources are used as input to the HSPF model including rainfall data, potential evapotranspiration, and other meteorological parameters; land cover and land use; and soil characteristics. The outputs of an HSPF model are simulated time series of suspended concentrations, sediment loads, or both, as well as streamflow; the time series are for a user-specified interval, or time step. A 1-hour time step was used for this study. HSPF also can simulate other water-quality constituents, including nutrients, metals, and organic compounds. Simulations for this study were limited to streamflow and suspended sediment.

Continuous (hourly) models enable simulation of important watershed processes for a full range of streamflows. Ockerman and Roussel (2009, p. 4) noted other investigators' findings that "the relative importance of various processes and factors influencing water quality can vary considerably with the magnitude of streamflow. For example, processes that appreciably affect water-quality conditions during low flows might have relatively minor effects on water-quality conditions during high flows. For assessment of peakstreamflow characteristics, continuous simulation models can provide a more realistic evaluation of antecedent soil-moisture conditions than is generally possible with event-based models (Martin and others, 2001, p. 66).”

\section{Functional Description of Hydrological Simulation Program-FORTRAN}

HSPF, a continuous, semi-lumped parameter model (Singh, 1995), provides continuous water and mass balance by tracking rainfall and water-quality constituents through the conceptual pathways of the hydrologic cycle. In HSPF, a watershed is represented by a group of hydrologically similar areas referred to as hydrologic response units (HRUs) that drain to a stream segment, lake, or reservoir referred to as a ReaCH REServoir (RCHRES). HRUs are areas in a subwatershed that have similar hydrologic and water-quality characteristics that are determined on the basis of land use, surficial geology, soil characteristics, and other factors that are deemed to produce similar hydrologic responses to rainfall and potential evapotranspiration. HRUs are categorized as pervious or impervious land segments, termed PERvious LaND (PERLND) or IMPervious LaND (IMPLND), respectively. A PERLND is represented conceptually within HSPF by three interconnected waterstorage zones - an upper zone, a lower zone, and a groundwater zone. An IMPLND is represented by surface storage, evaporation, and runoff processes. Each RCHRES is associated with a particular subwatershed and receives the runoff, sediment, and chemical loads from the PERLNDs and IMPLNDs in the subwatershed. The hydraulics of a RCHRES are simulated by a storage routing method (Donigian and others, 1995). 
Table 3. Suspended-sediment sampling results, lower Nueces River watershed, south Texas, 2006-7, 2010.

[ft³/s, cubic feet per second; mm, millimeters; mg/L, milligrams per liter; mm, millimeters; tons/day, tons per day]

Station 08211000 Nueces River near Mathis, Tex.

\begin{tabular}{|c|c|c|c|c|c|}
\hline Sample date & $\begin{array}{c}\text { Measured } \\
\text { streamflow } \\
\left(\mathrm{ft}^{3} / \mathrm{s}\right)\end{array}$ & $\begin{array}{l}\text { Measured sediment } \\
\text { particle diameter } \\
\text { less than } 0.0625 \mathrm{~mm} \\
\text { (percent) }^{1}\end{array}$ & $\begin{array}{c}\text { Measured } \\
\text { suspended- } \\
\text { sediment } \\
\text { concentration } \\
\text { (mg/L) }\end{array}$ & $\begin{array}{l}\text { Measured } \\
\text { suspended- } \\
\text { sediment load } \\
\text { (tons/day) }\end{array}$ & $\begin{array}{l}\text { Suspended-sediment } \\
\text { concentration } \\
\text { relative percent } \\
\text { difference }^{2}\end{array}$ \\
\hline May 17, 2006 (environmental sample) & 139 & 98 & 24 & 8.9 & -- \\
\hline May 17, 2006 (replicate sample) & 139 & 90 & 29 & 11 & 19 \\
\hline July 20, 2006 (environmental sample) & 110 & 88 & 26 & 8.3 & -- \\
\hline Sept. 5, 2006 & 138 & 99 & 24 & 8.7 & -- \\
\hline Nov. 20, 2006 & 72 & 94 & 22 & 4.3 & -- \\
\hline May 26, 2007 & 461 & 99 & 16 & 21 & -- \\
\hline May 29, 2007 & 1,190 & 98 & 12 & 39 & -- \\
\hline July 1, 2007 & 4,830 & 98 & 16 & 215 & -- \\
\hline
\end{tabular}

Station 08211050 Bayou Creek at Farm Road 666 near Mathis, Tex.

\begin{tabular}{lcccr}
\hline Sample date & $\begin{array}{c}\text { Measured } \\
\text { streamflow } \\
\left(\mathbf{f t}^{3} / \mathbf{s}\right)\end{array}$ & $\begin{array}{c}\text { Measured sediment } \\
\text { particle diameter } \\
\text { less than } \mathbf{0 . 0 6 2 5} \mathbf{~ m m} \\
\text { (percent) }\end{array}$ & $\begin{array}{c}\text { Measured suspended- } \\
\text { sediment load } \\
\text { (mg/L) }\end{array}$ & $\begin{array}{c}\text { Measured suspended- } \\
\text { sediment load } \\
\text { (tons/day) }\end{array}$ \\
\hline Sept. 7, 2010 & 140 & 83 & 467 & 177 \\
Sept. 19, 2010 & 1,860 & 76 & 474 & 2,380 \\
\hline
\end{tabular}

Station 08211200 Nueces River at Bluntzer, Tex.

\begin{tabular}{|c|c|c|c|c|c|}
\hline Sample date & $\begin{array}{l}\text { Measured } \\
\text { streamflow } \\
\quad\left(\mathrm{ft}^{3} / \mathrm{s}\right)\end{array}$ & $\begin{array}{l}\text { Measured sediment } \\
\text { particle diameter } \\
\text { less than } 0.625 \mathrm{~mm} \\
\text { (percent) }\end{array}$ & $\begin{array}{c}\text { Measured } \\
\text { suspended- } \\
\text { sediment } \\
\text { concentration } \\
\text { (mg/L) } \\
\end{array}$ & $\begin{array}{l}\text { Measured } \\
\text { suspended- } \\
\text { sediment load } \\
\text { (tons/day) }\end{array}$ & $\begin{array}{l}\text { Suspended-sediment } \\
\text { concentration } \\
\text { relative percent } \\
\text { difference }^{2}\end{array}$ \\
\hline May 17,2006 & 121 & 97 & 48 & 16 & -- \\
\hline May 17, 2006 (replicate sample) & 121 & 98 & 45 & 15 & -6.5 \\
\hline Sept. 5, 2006 & 136 & 97 & 52 & 19 & -- \\
\hline Sept. 19, 2006 & 1,050 & 97 & 1,070 & 3,040 & -- \\
\hline Nov. 20, 2006 & 82 & 89 & 25 & 5.5 & -- \\
\hline Jan. 4, 2007 & 153 & 81 & 293 & 121 & -- \\
\hline Jan. 25, 2007 & 243 & 99 & 760 & 499 & -- \\
\hline July 11, 2007 & 15,000 & 79 & 40 & 1,620 & -- \\
\hline Sept. 7, 2010 & 160 & 78 & 78 & 34 & -- \\
\hline Sept. 19, 2010 & 1,500 & 85 & 540 & 2,190 & -- \\
\hline Sept. 20, 2010 & 4,270 & 94 & 206 & 2,370 & -- \\
\hline
\end{tabular}


Table 3. Suspended-sediment sampling results, lower Nueces River watershed, south Texas, 2006-7, 2010. - Continued

$\left[\mathrm{ft}^{3} / \mathrm{s}\right.$, cubic feet per second; $\mathrm{mm}$, millimeters; $\mathrm{mg} / \mathrm{L}$, milligrams per liter; mm, millimeters; tons/day, tons per day]

Station 08211500 Nueces River at Calallen, Tex.

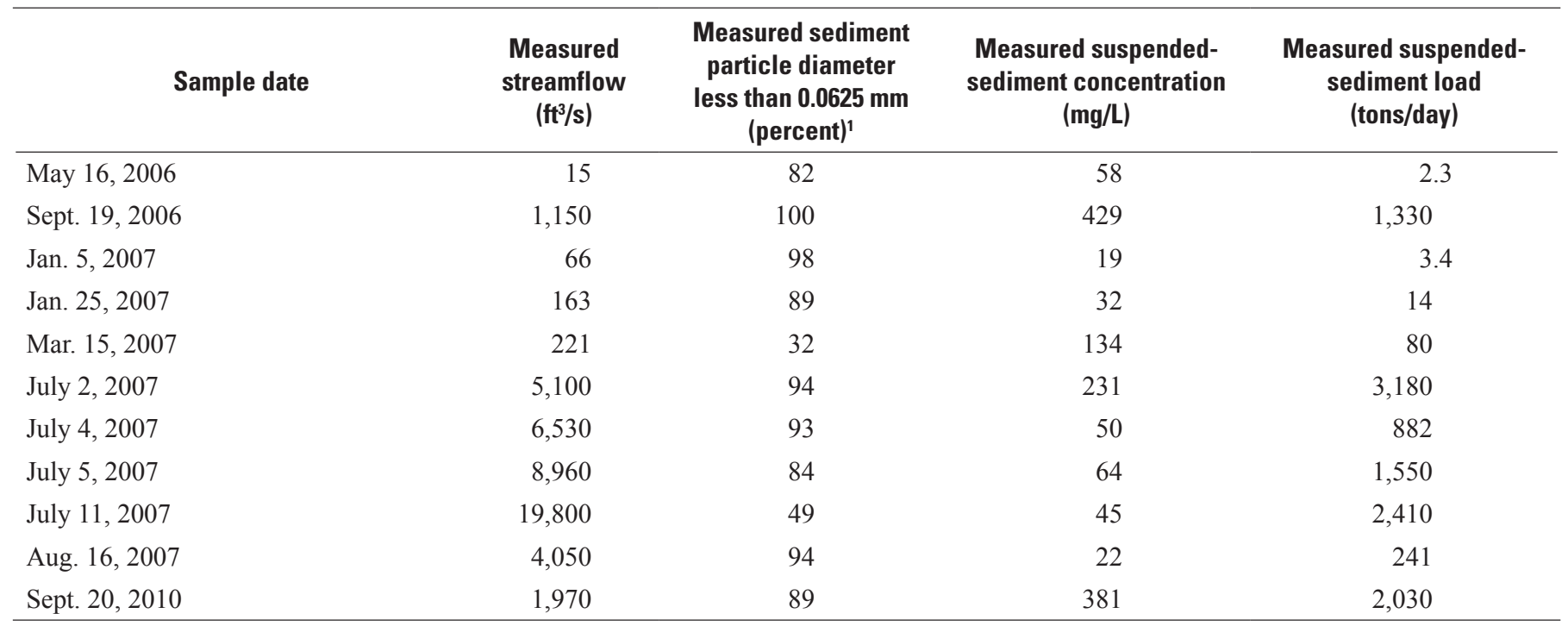

${ }^{1}$ Percent by weight of sediment sample that passes through a 0.0625 millimeter sieve.

${ }^{2}$ Relative percent difference is [|sample 1 - sample $2 / /($ sample $1+$ sample 2$\left.) / 2\right] \times 100$.

HSPF is composed of a series of computational routines that separately simulate processes of the hydrologic cycle. Specifically, HSPF simulates the hydrologic cycle as an interconnected series of storage (and processing) segments with water fluxes (volume per unit area per unit time) and constituent fluxes (mass [weight] per unit area per unit time) moving between the various storages. Figure 4 shows a flowchart of HSPF hydrologic processes for IMPLNDs and PERLNDs. Figure 5 shows a flowchart of HSPF sediment processes for IMPLNDs, PERLNDs, and RCHRESs. The movement of water and suspended sediment from IMPLNDs and PERLNDs and between storage zones is controlled by various process-related parameters. Although some parameters are directly measurable, most are estimated during model calibration (Martin and others, 2001).

The HSPF model of the lower Nueces River watershed was developed by (1) compiling and processing required input data, (2) configuring the model to represent the watershed, (3) calibrating the model to improve simulation accuracy, and (4) comparing calibrated model simulations with additional streamflow and suspended-sediment data to test the model simulation accuracy. The definitions of the HSPF model process parameters used in the lower Nueces River watershed model are listed in appendix 1. A complete description of the computational processes and required input model parameters is provided in the HSPF users' manual (Bicknell and others, 2001).

\section{Previous Watershed Modeling Study and Report}

As described in the "Introduction" section of this report, the USGS, in cooperation with the USACE and other cooperators, published a report that documented the calibration of a watershed model and use of the model to simulate streamflow and suspended-sediment concentrations and loads in the lower Nueces River for the period 19582008 (Ockerman and Heitmuller, 2010). Because of interest in Nueces River suspended-sediment conditions during a runoff event in November 2009, and with the collection of additional suspended-sediment data in 2010, the previous model was updated to extend the simulation period through 2010.

The original model by Ockerman and Heitmuller (2010) was configured according to land-cover categories and was well suited for simulating sources of sediment during runoff events. Updating of the original model for this study involved extending the simulation period by including the necessary model input data (rainfall, potential evapotranspiration, inflow from releases from Lake Corpus Christi, and withdrawals) for the period 2009-10. The model configuration data and model calibration parameters remained unchanged from the original model. 
A . Impervious land segments

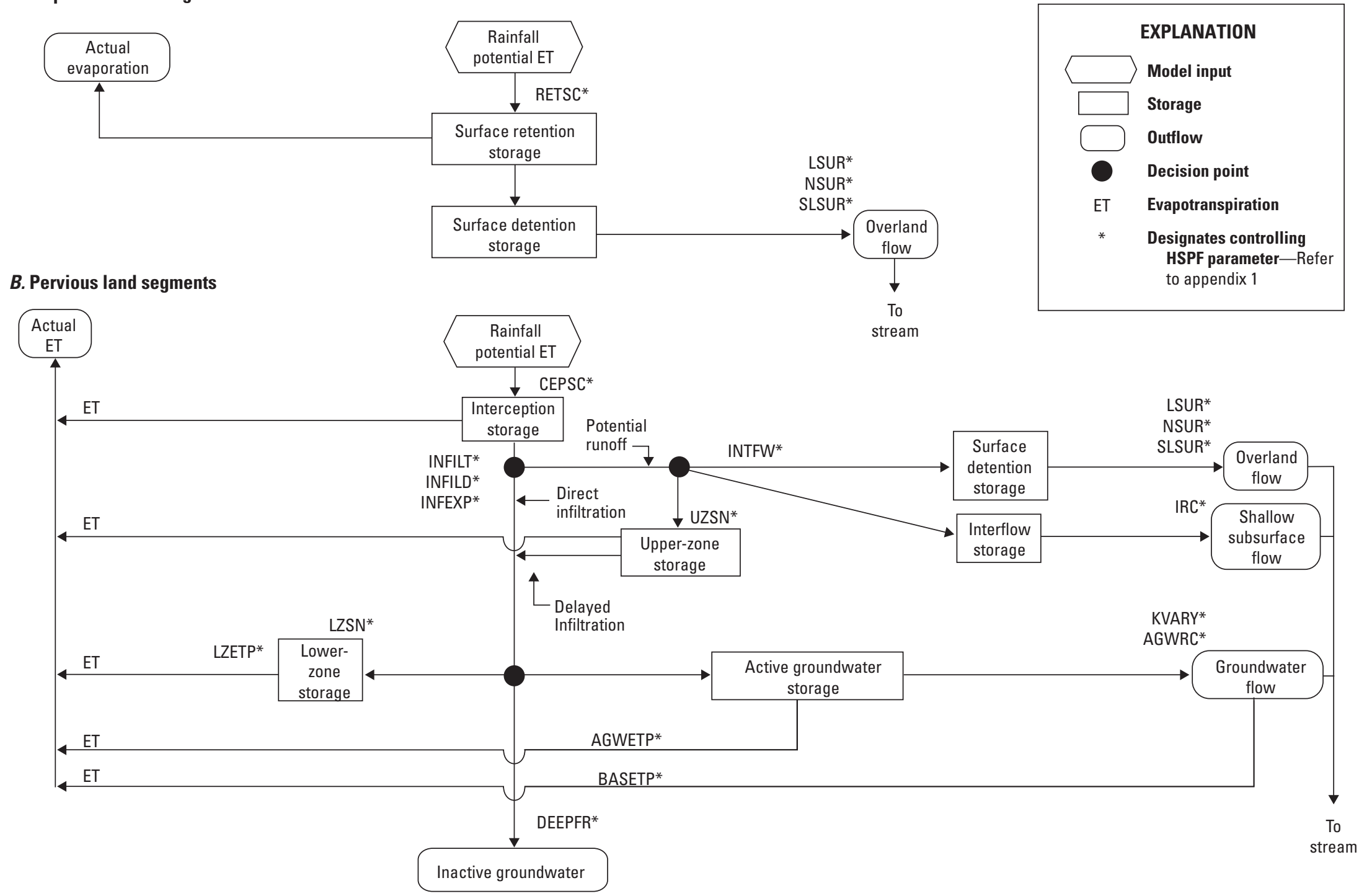

Figure 4. Hydrological Simulation Program—FORTRAN (HSPF) flowchart for hydrologic processes on $A$, impervious and $B$, pervious land segments. 


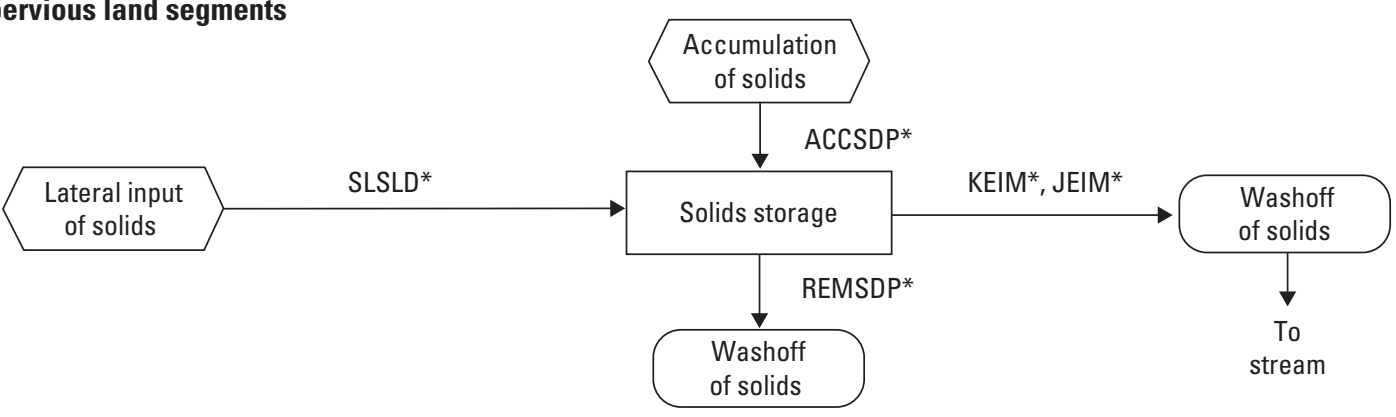

B. Pervious land segments
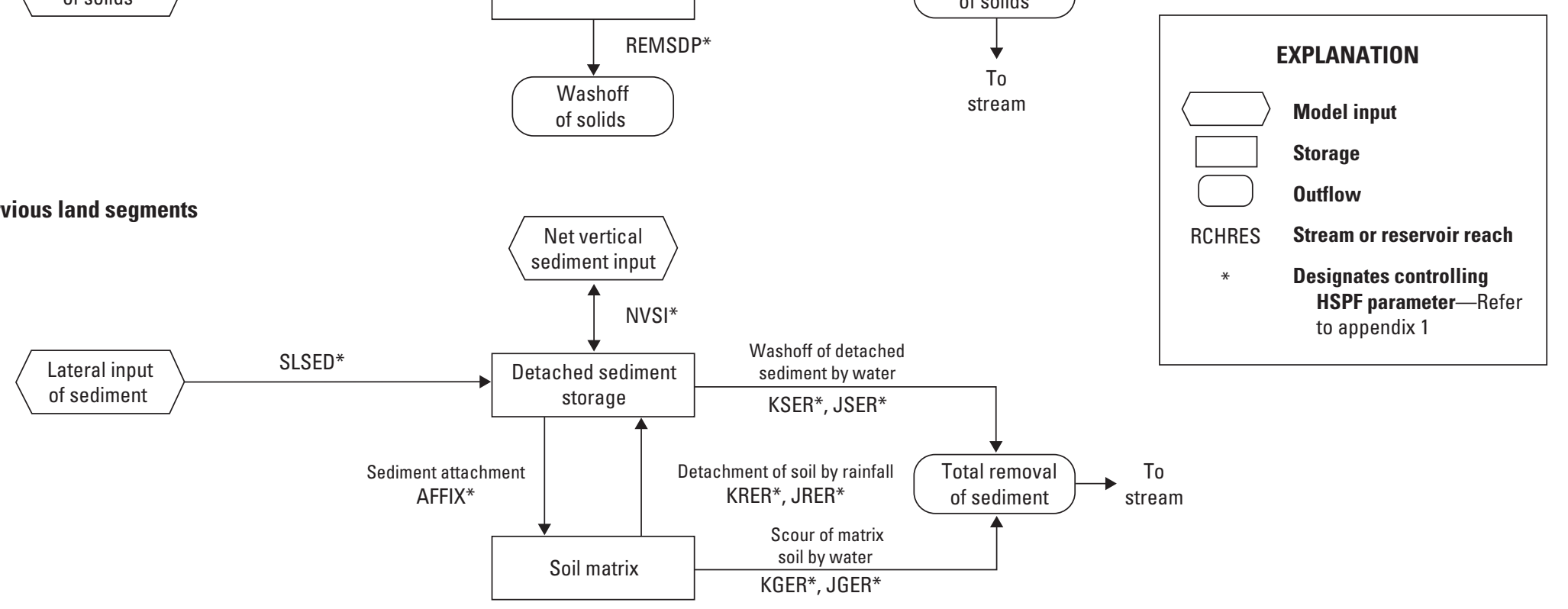

\section{Stream reaches}

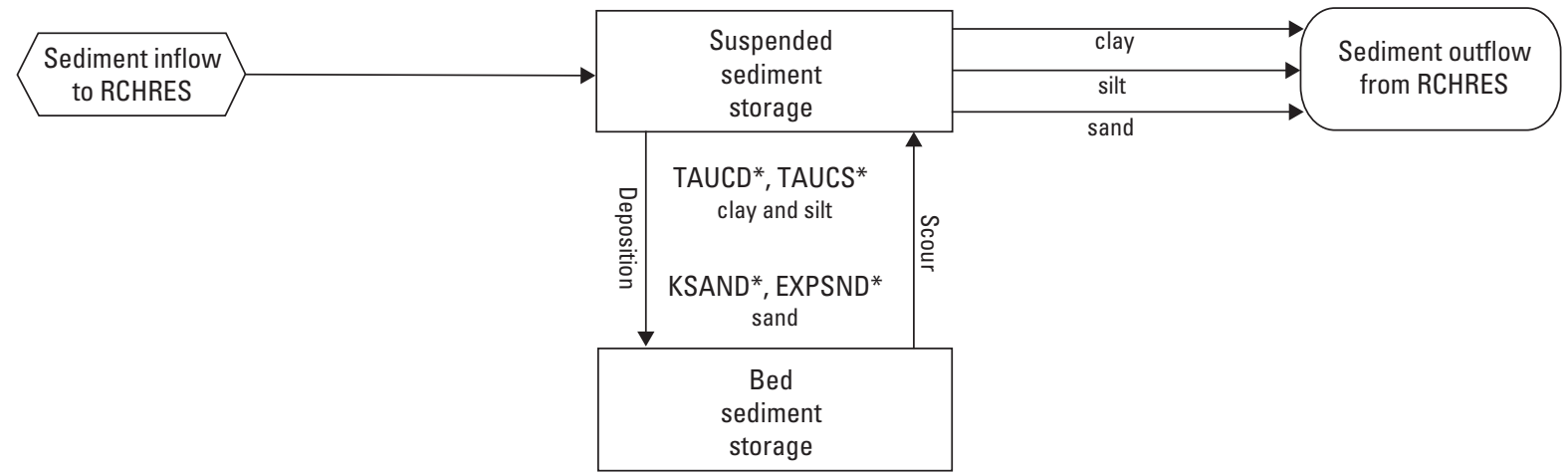

Figure 5. Hiagram showing Hydrological Simulation Program—FORTRAN (HSPF) flowchart for sediment processes on $A$, impervious land segments, $B$, pervious land segments, and $C$, stream reaches. 


\section{Input Data for the Lower Nueces River Watershed Model}

Input data for the lower Nueces River watershed model included spatial data (land cover, geology, soils, topography, and drainage characteristics such as subwatershed boundaries and stream-reach length and cross-section data) and timesseries data, including meteorological data (rainfall and potential evapotranspiration), streamflow data, and suspendedsediment load data. Spatial data were used to create the model HRUs and RCHRESs. Streamflow and suspended-sediment data were used to calibrate the model.

Land-cover data for the study area were obtained from the U.S. Environmental Protection Agency's Multi-Resolution Land Characteristics Consortium (Homer and others, 2004). In the lower Nueces River watershed, there were 15 land covers and land uses as classified by the 2001 National Land Cover Database (NLCD) (Multi-Resolution Land Characteristics Consortium, 2008). To simplify the model configuration, the 15 classes were reclassified into 8 land-cover categories shown on figure 6 . Areas classified as open water were modeled as part of a RCHRES. Developed land use was principally classified as low-intensity development, of which about 15 percent was simulated as impervious area. Barren land was grouped with developed open space and the resulting acreage also was considered to be 15 percent impervious.

Surficial geology data (fig. 7) were obtained from two areal geologic maps published in the "Geologic Atlas of Texas" by the University of Texas Bureau of Economic Geology for the lower Nueces River study area: Beeville-Bay City sheet (Aronow and others, 1975) and Corpus Christi sheet (Aronow and Barnes, 1975). The predominant surficial geology of the most upstream parts of the study area includes the Pleistocene-age Lissie and Deweyville Formations. In the rest of the study area, the surficial geology consists of the Beaumont Formation (Pleistocene age) or alluvium (Holocene age) (Aronow and Barnes, 1975). In the Lissie and Deweyville Formations, the sediments, in order of dominance, consist mostly of sand, silt, and clay. In the Beaumont Formation and alluvium, the sediments, in order of dominance, consist mostly of clay, silt, and sand (Minzenmayer, 1979). The data obtained from the Beeville-Bay City sheet (northern part of the study area) provide a more detailed breakdown of the areas of the Beaumont Formation that are dominated by clay or sand, compared with the data available from the Corpus Christi sheet (southern part of the study area).

Soils data for the study area were compiled from the U.S. Department of Agriculture, Natural Resources Conservation Service (2009) "Soil Survey Geographic (SSURGO) Database." These data were used to provide initial estimates for selected HSPF process-related parameter values, primarily soil infiltration rate (INFILT). Figure 8 shows the relative soil infiltration rates for the study area.

Topography (slope) data for the study area were obtained from USGS 7.5-minute digital elevation models (U.S. Geological Survey, 2013b). The digital elevation models also were used to delineate subwatersheds as part of the HSPF model development. The study area was subdivided into 64 subwatersheds (fig. 9). The average size of each subwatershed is 2,000 acres. The model stream segment (RCHRES) that is associated with each subwatershed is identified with the same identification number as the subwatershed identification number (fig. 9). Spatial data for streams (location and reach length) were obtained from the "National Hydrography Dataset" (U.S. Geological Survey, 2009). Stream-channel cross-section data were obtained from streamflow-discharge measurements made at USGS streamflow-gaging stations in the study area (U.S. Geological Survey, 2010).

Much of the streamflow in the lower Nueces River originates as releases from Wesley E. Seale Dam. These releases are measured at the USGS Mathis gage. The Mathis gage streamflow data were used as input to the upstream boundary of the model, providing a relatively accurate accounting for inflow to the model (U.S. Geological Survey, 2013a). Other USGS streamflow-gaging stations in the study area provided data that were used for calibration and testing of the model simulations. Location information, type of data collected, and period of record for sites that provided streamflow data for the lower Nueces River watershed are listed in table 4. Locations of the streamflow-gaging stations are shown on figure 10.

Water is withdrawn from the Nueces River for municipal and industrial uses in RCHRES 82 and 84 (fig. 9). During 2001-10, these withdrawals averaged 64,500 acre-ft/yr or the flow volume equivalent to a continuous flow of about $89 \mathrm{ft}^{3} / \mathrm{s}$ (Nueces River Authority, 2013); withdrawal data are available as monthly totals. Within HSPF, the monthly total withdrawals were disaggregated to hourly values and input to the model. 


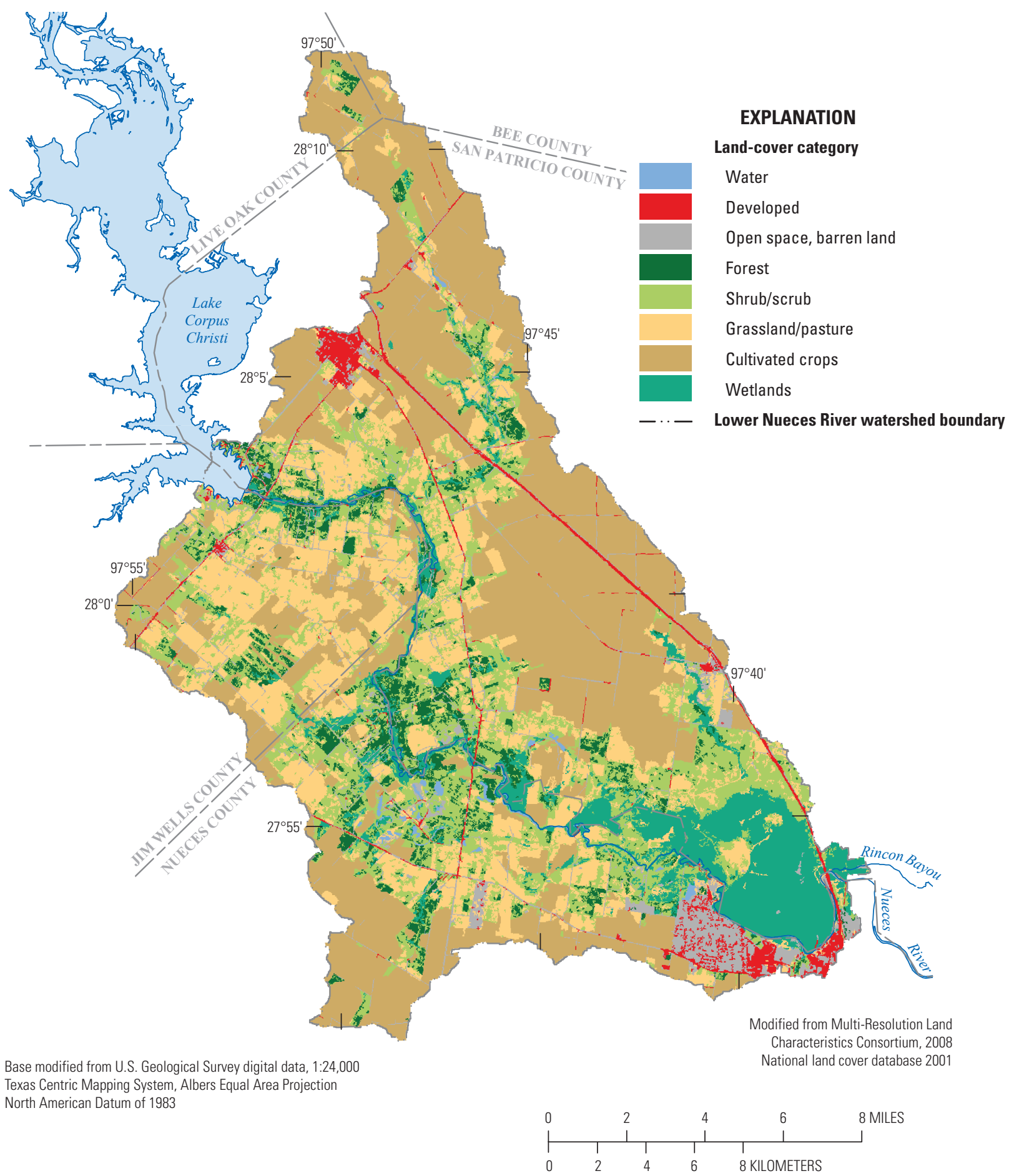

Figure 6. Land-cover categories in the lower Nueces River watershed, south Texas. 


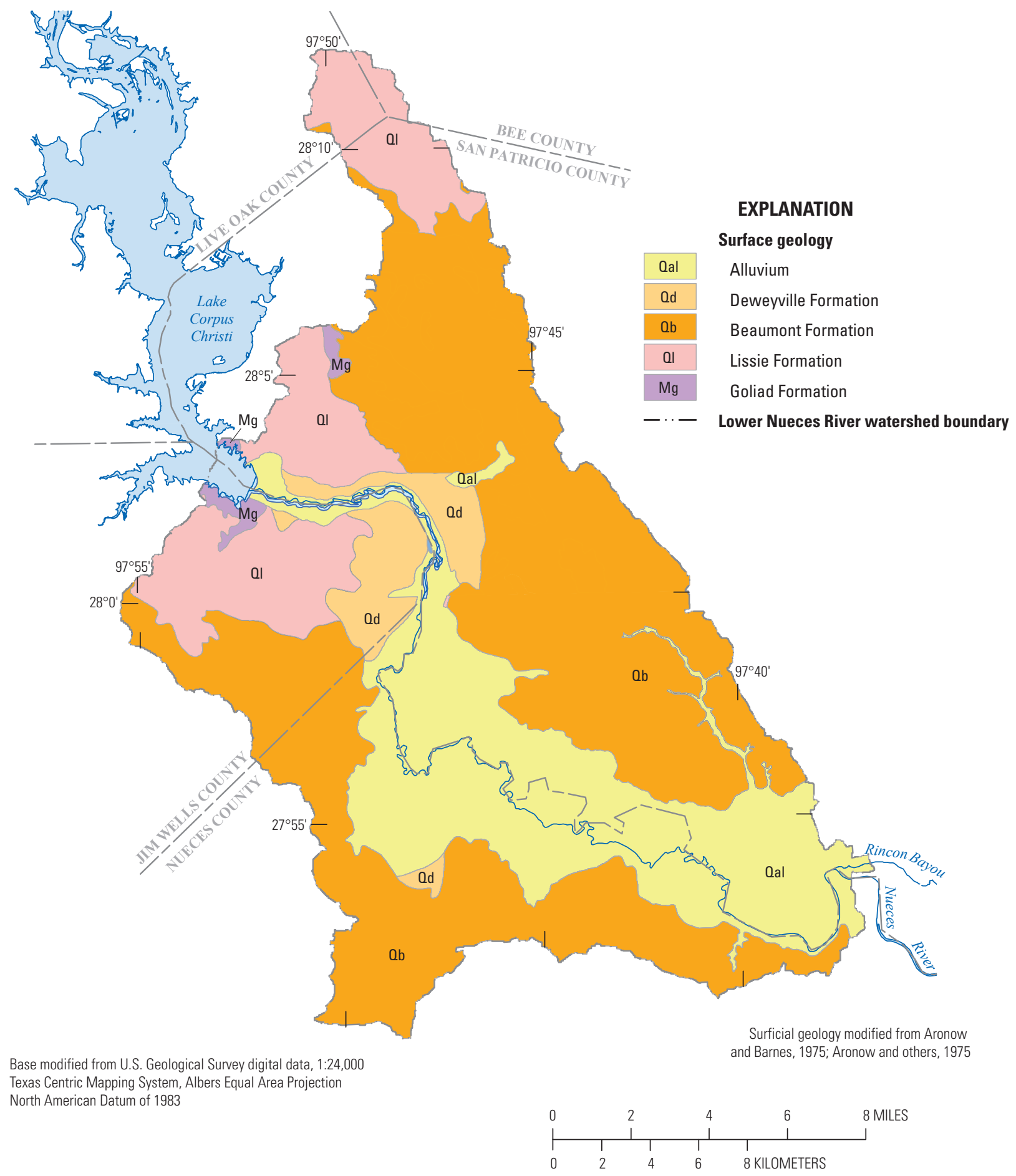

Figure 7. Surficial geology of the lower Nueces River watershed, south Texas. 


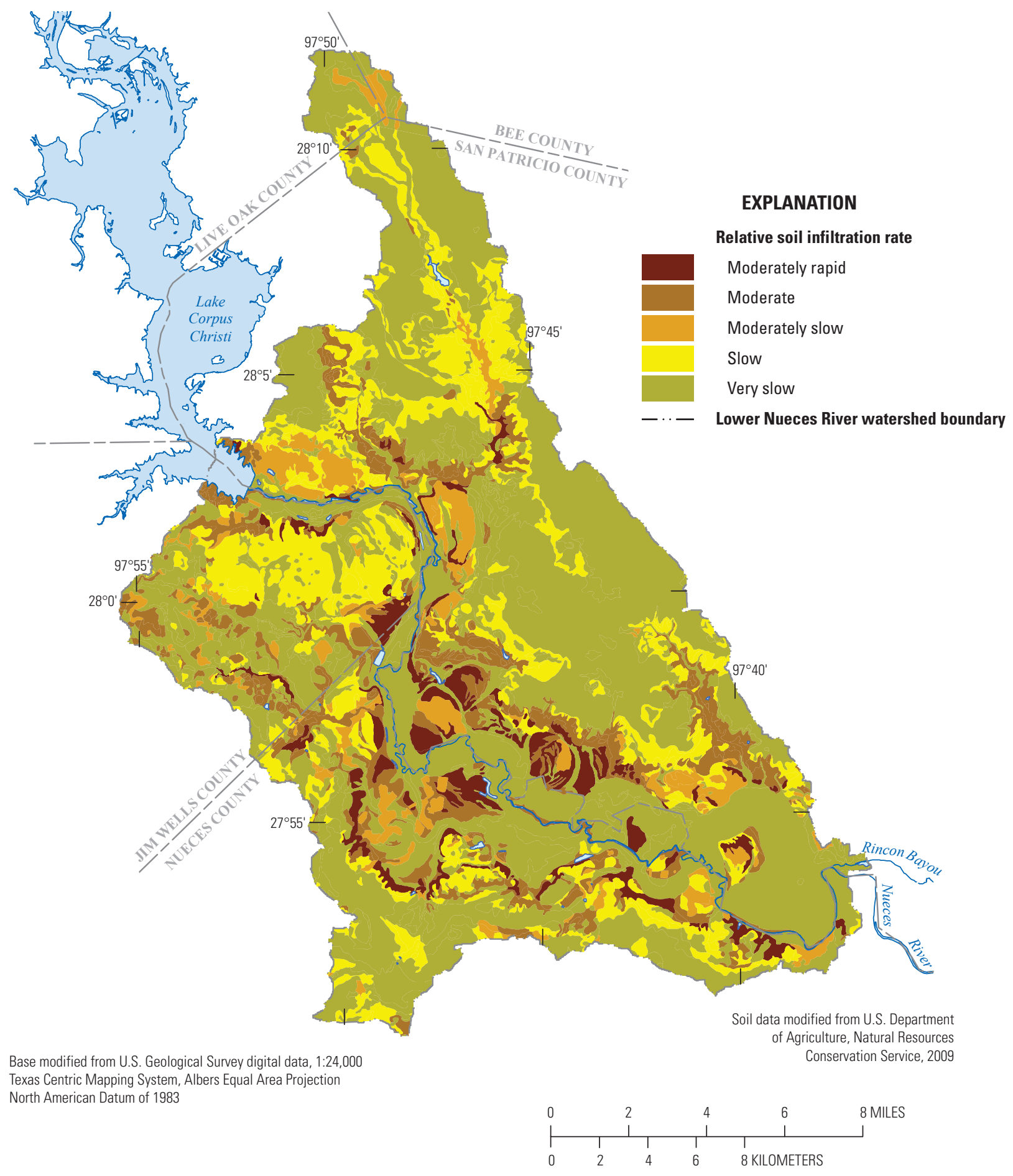

Figure 8. Relative soil infiltration rates in the lower Nueces River watershed, south Texas. 


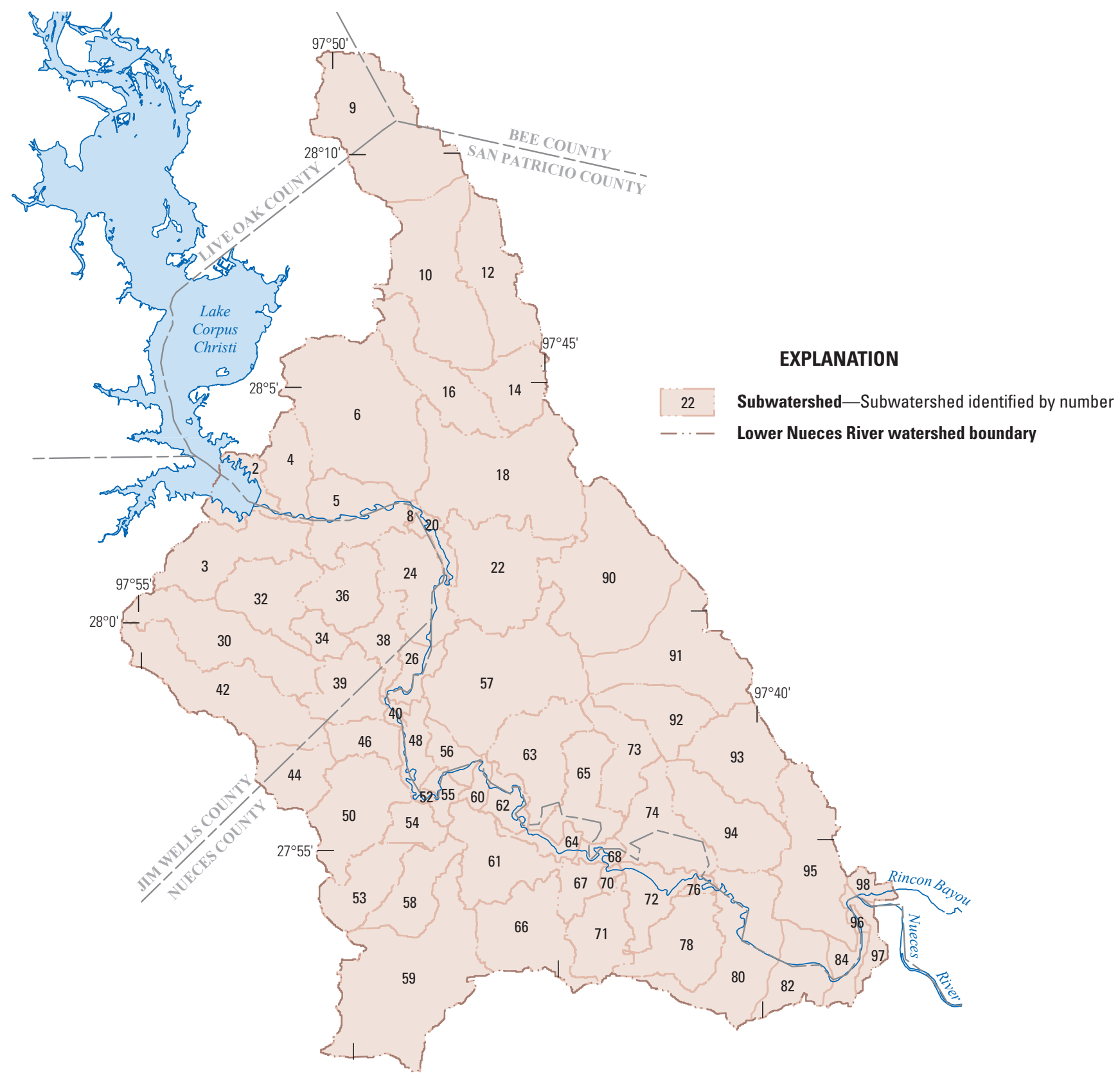

Base modified from U.S. Geological Survey digital data, 1:24,000

Texas Centric Mapping System, Albers Equal Area Projection

North American Datum of 1983

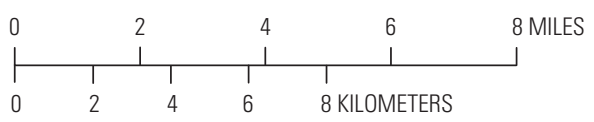

Figure 9. Subwatershed delineation for the lower Nueces River watershed model, south Texas. 
Table 4. Data-collection sites providing data for the lower Nueces River watershed model, south Texas.

[ddmmss, degrees minutes seconds; NWS, National Weather Service; ID, identifier; --, not available; max, maximum; min, minimum; temp, temperature; USGS, U.S. Geological Survey]

\begin{tabular}{|c|c|c|c|c|}
\hline $\begin{array}{c}\text { Site } \\
\text { number } \\
\text { (figs. 2, 10) }\end{array}$ & Station number and name & $\begin{array}{l}\text { Latitude } \\
\text { (ddmmss) }\end{array}$ & $\begin{array}{l}\text { Longitude } \\
\text { (ddmmss) }\end{array}$ & $\begin{array}{c}\text { Type of data } \\
\text { (period of record available) }\end{array}$ \\
\hline 1 & $\begin{array}{l}\text { NWS station Coop ID 415661, Mathis, Jim Wells } \\
\text { County, Tex. }\end{array}$ & $28^{\circ} 06^{\prime}--^{\prime \prime}$ & $97^{\circ} 49^{\prime}--^{\prime \prime}$ & $\begin{array}{l}\text { Daily rainfall and daily max and min air } \\
\text { temp (1957-77) }\end{array}$ \\
\hline 2 & $\begin{array}{l}\text { NWS station Coop ID 415661, Mathis } 4 \text { SSW, Jim } \\
\text { Wells County, Tex. }\end{array}$ & $28^{\circ} 02^{\prime} 14^{\prime \prime}$ & $97^{\circ} 52^{\prime} 21^{\prime \prime}$ & $\begin{array}{l}\text { Daily rainfall and daily max and min air } \\
\text { temp (1977-2010) }\end{array}$ \\
\hline 4 & $\begin{array}{l}\text { NWS station WBAN ID 12984, Robstown Airport, } \\
\text { Nueces County, Tex. }\end{array}$ & $27^{\circ} 46^{\prime} 43^{\prime \prime}$ & $97^{\circ} 41^{\prime} 26^{\prime \prime}$ & Hourly rainfall $(2003-10)$ \\
\hline 5 & $\begin{array}{l}\text { NWS station COOP ID 412015, Corpus Christi } \\
\text { International Airport, Nueces County, Tex. }\end{array}$ & $27^{\circ} 46^{\prime} 27^{\prime \prime}$ & $97^{\circ} 30^{\prime} 44^{\prime \prime}$ & $\begin{array}{l}\text { Daily rainfall and daily max and min air } \\
\text { temp (1960-2010) }\end{array}$ \\
\hline 6 & $\begin{array}{l}\text { NWS station COOP ID 412015, Corpus Christi Maus } \\
\text { Field, Nueces County, Tex. }\end{array}$ & $27^{\circ} 46^{\prime}--^{\prime \prime}$ & $97^{\circ} 27^{\prime}--^{\prime \prime}$ & $\begin{array}{l}\text { Daily rainfall and daily max and min air } \\
\text { temp (1934-60) }\end{array}$ \\
\hline 9 & $\begin{array}{l}\text { USGS streamgaging station } 08211200 \text { Nueces River at } \\
\text { Bluntzer, Tex. } \\
\text { (partial-record station) }\end{array}$ & $27^{\circ} 56^{\prime} 15^{\prime \prime}$ & $97^{\circ} 46^{\prime} 32^{\prime \prime}$ & $\begin{array}{l}\text { Streamflow (2005-10); suspended sediment } \\
\quad(2006-7,2010)\end{array}$ \\
\hline 10 & $\begin{array}{l}\text { USGS streamgaging station } 08211500 \text { Nueces River at } \\
\text { Calallen, Tex. }\end{array}$ & $27^{\circ} 52^{\prime} 58^{\prime \prime}$ & $97^{\circ} 37^{\prime} 30^{\prime \prime}$ & $\begin{array}{l}\text { Streamflow (2001-10); suspended sediment } \\
\quad(2006-8,2010)\end{array}$ \\
\hline 11 & $\begin{array}{l}\text { USGS streamgaging station } 08211502 \text { Nueces River } \\
\text { near Odem, Tex. } \\
\text { (partial-record station) }\end{array}$ & $27^{\circ} 53^{\prime} 42^{\prime \prime}$ & $97^{\circ} 37^{\prime} 43^{\prime \prime}$ & $\begin{array}{l}\text { Streamflow (flood discharge measurements, } \\
\text { 2001-8) }\end{array}$ \\
\hline 12 & $\begin{array}{l}\text { USGS streamgaging station } 08211050 \text { Bayou Creek at } \\
\text { Farm Road } 666 \text { near Mathis, Tex. } \\
\text { (partial-record station) }\end{array}$ & $28^{\circ} 02^{\prime} 36^{\prime \prime}$ & $97^{\circ} 47^{\prime} 20^{\prime \prime}$ & $\begin{array}{l}\text { Streamflow (flood discharge measurements, } \\
\text { 2010); suspended sediment (2010) }\end{array}$ \\
\hline
\end{tabular}

Rainfall and air temperature data were obtained from NWS stations Mathis, Mathis 4 SSW, Robstown, Robstown Airport (rainfall only), Corpus Christi International Airport, and Corpus Christi Maus Field (sites 1-6, respectively, fig. 10; table 4). The NWS has operated rainfall stations in Mathis and Robstown since 1957 and 1947, respectively. The Mathis 4 SSW station replaced the Mathis station in 1977. The Robstown station has been in operation since 1947 and the Robstown Airport station since 2003. The Mathis and Mathis 4 SSW stations (sites 1 and 2, respectively, fig. 10; table 4) and the Robstown and Robstown Airport stations (sites 3 and 4, respectively, fig. 10; table 4) were the primary sources of rainfall data. For modeling purposes, the data from the two Mathis stations were combined, and the location of the rainfall data time series was considered to be the same as the newer Mathis 4 SSW station. Similarly, data from the two Robstown stations were combined into a single time series that was considered to be located at the newer Robstown Airport station. These time series and associated locations were then used for the entire simulation period. The spatial application of rainfall time-series data to the model is based on a Theissen polygon distribution (Linsley and others, 1982).
Two rainfall areas were defined by the Theissen boundary as shown on figure 10. Rainfall to the upstream area of the watershed was simulated using the Mathis station data, and rainfall to the downstream area of the watershed was simulated using the Robstown station data. Rainfall data from the Corpus Christi International Airport, Corpus Christi Maus Field, and Alice stations (sites 5, 6, and 7, respectively, fig. 10; table 4) were used to fill periods of missing data when data from the Mathis or Robstown stations were not available.

Time series of potential evapotranspiration (PEVT) data are used in HSPF to set the upper limit of actual evapotranspiration (ET) that can be simulated for any of the HRUs. PEVT is the observed ET if there is an unlimited supply of water to satisfy the potential ET rate (Wanielista, 1990). PEVT was computed from maximum and minimum daily air temperature (from NWS station data) using the Hamon method (Bidlake, 2002). Similar to the sources of rainfall data, the primary sources of air temperature data were the Mathis and Robstown NWS stations. PEVT time-series data were applied to delineated subwatersheds according to the Theissen boundary shown on figure 10 . 


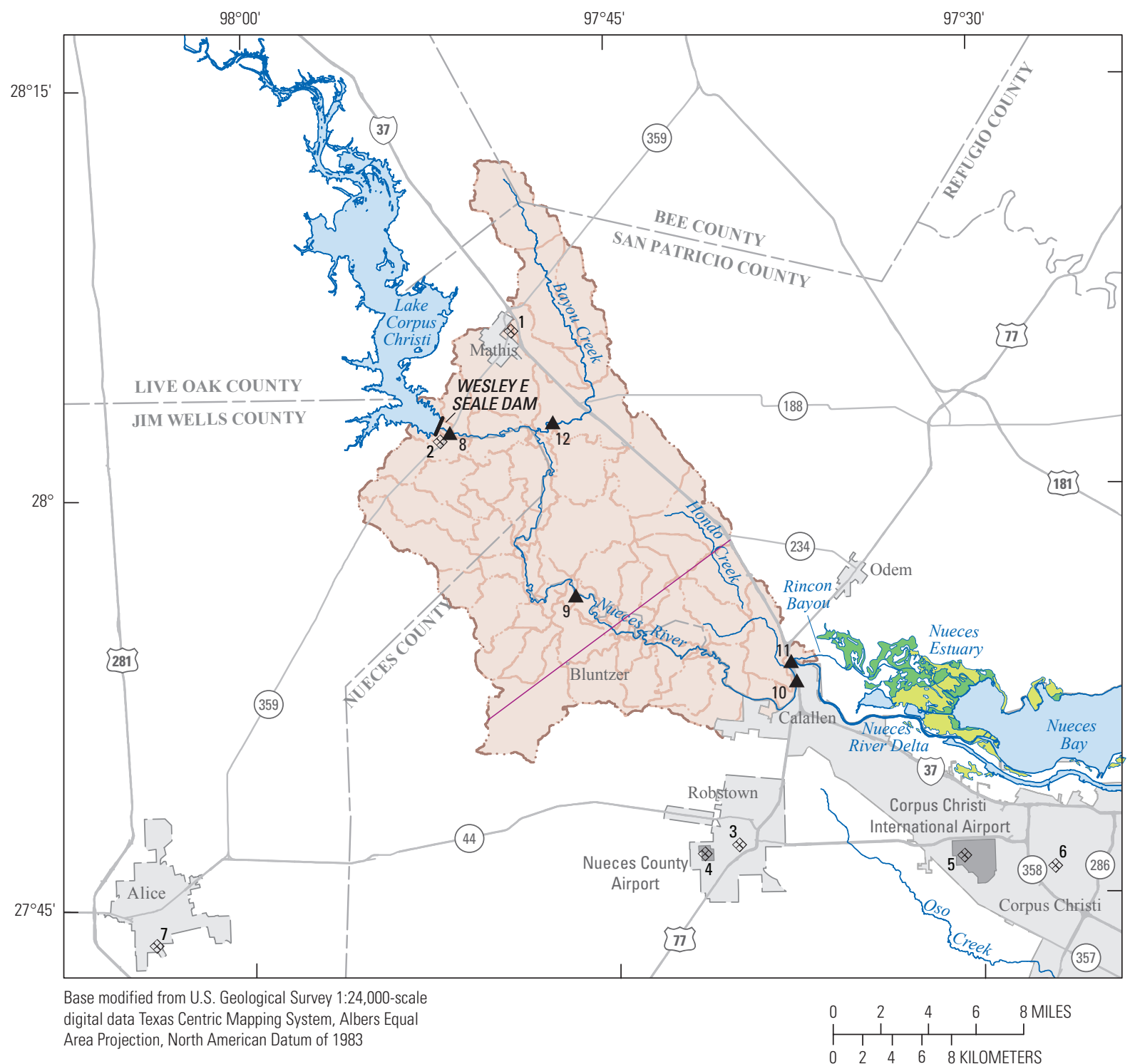

EXPLANATION

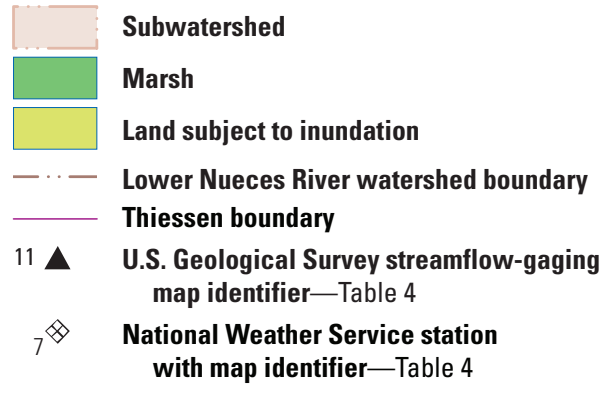

Figure 10. Locations of U.S. Geological Survey streamflow-gaging stations and National Weather Service rainfall stations (with associated Thiessen rainfall areas) providing data for the lower Nueces River watershed model, south Texas. 


\section{Model Development}

To develop the model, the stream network of the lower Nueces River watershed was segmented into subwatersheds (fig. 9), generally on the basis of (1) similar streamflow traveltimes that approximated the model time step (1 hour), (2) homogeneous channel properties such as slope and conveyance, and (3) outlets of subwatersheds at points of interest such as streamflow-gaging stations, major tributary confluences, and points of water withdrawals.

In each subwatershed, unique pervious and impervious HRUs were defined according to three factors: (1) land cover and land use, (2) surficial geology and soil characteristics, and (3) the location of the nearest rainfall station (to spatially distribute meteorological input data [rainfall and PEVT]). Spatial information describing these three factors was compiled and analyzed using the Geographical Information System software ArcGIS (Esri, 2009) to compute the acreage of each HRU within a given subwatershed.

\section{Model Calibration}

A primary goal of model calibration was to adjust the process-related parameter values to minimize the differences between measured and simulated flows at a streamflowgaging station. The model was calibrated in accordance with guidelines by Donigian and others (1984) and Lumb and others (1994). The calibration of the model proceeded in two steps: (1) parameters related to hydrologic processes were calibrated, and (2) parameters related to suspended-sediment processes were calibrated. Calibration of hydrologic processes included adjusting appropriate model parameters to minimize differences between measured and simulated streamflow at streamflow-gaging stations during 2001-8 over a wide range of hydrologic conditions. Model parameters that control landsurface erosion and washoff processes and instream sediment transport processes were adjusted to minimize differences between measured and simulated suspended-sediment concentrations and loads.

\section{Hydrology}

To evaluate the goodness of fit between measured and simulated streamflows, simulation errors were evaluated by comparing total streamflow volume, 50 percent lowest daily flows, and 10 percent highest daily flows. Donigian and others (1984) presented general guidelines for characterizing the goodness of fit of HSPF calibrations. For annual and monthly streamflow volumes, model calibration is considered very good when the error is less than 10 percent, good when the error is $10-15$ percent, and fair when the error is $15-25$ percent.

Additionally, model-fit statistics generated by the software program GENeration and analysis of model simulation SCeNarios (GenScn) for watersheds (Kittle and others, 1998) were used to examine the quality of the model fit on an annual, monthly, daily, and hourly basis for the (1) coefficient of determination (R-squared $\left[R^{2}\right]$ ) of the linear regression between measured and simulated streamflow (Ott and Longnecker, 2001), (2) Nash-Sutcliffe coefficient of model-fit efficiency (NSE) (Nash and Sutcliffe, 1970), (3) mean absolute error (MAE) (StatSoft, Inc., 2010), and (4) root mean square error (RMSE) (StatSoft, Inc., 2010). The $\mathrm{R}^{2}$ and NSE are similar because each provides a measure of the variation in the measured values explained by the simulated values. The NSE, however, provides a generally preferable evaluation of the fit quality compared with the R2 because the NSE measures the magnitude of the differences between measured and simulated values, whereas, the $\mathrm{R}^{2}$ measures the difference between mean values (Zarriello and Ries, 2000, p. 44). MAE and RMSE express the difference between measured and simulated streamflow in original units (cubic foot per second) (StatSoft, Inc., 2010).

At selected calibration sites, depending on the availability of streamflow data, the calibration process included a separate, post-calibration test of the model fit. For sites where the testing process was performed, a subset of the observed streamflow-gaging data was randomly selected and not used during the calibration. After calibration, these withheld data were then used for testing the model fit between measured and simulated streamflow. Model simulations from 2009-10 were not part of the original model calibration and testing by Ockerman and Heitmuller (2010). When the original model simulation period was extended through 2010, 2009-10 simulated streamflow at the Calallen gage was compared with gaged steamflow as an additional testing process.

Most of the streamflow in the study area originated as releases from Lake Corpus Christi (fig. 1). The Mathis gage is located immediately downstream from the lake and monitors stream discharge from the lake. Daily discharges for this station during 1939-2010 were input to the model at the inlet of RCHRES 4 (fig. 9) as a boundary condition. Because actual gaged streamflow data were used as input to the model at this site, no model calibration was necessary at this station.

The Bluntzer gage (outlet of RCHRES 60, fig. 9) is operated as a partial-record station. Streamflows of more than $2,750 \mathrm{ft}^{3} / \mathrm{s}$ are not measured because streamflowgaging conditions are not favorable at higher flows. Because streamflow data from the Bluntzer gage were not suitable for calibration of the entire range of streamflow conditions, calibration of hydrologic parameters upstream from the Bluntzer gage was not based on data from this gage. During 2005-6, streamflow at the Bluntzer gage did not exceed $2,750 \mathrm{ft}^{3} / \mathrm{s}$, and the 2005-6 data were used as a test of the calibrated model. Streamflow testing results for the Bluntzer gage during 2005-6 (fig. 11; table 5) indicate very good agreement between measured and simulated streamflow volumes; the error in total simulated streamflow volume compared with measured streamflow volume during 2005-6 at this gage was less than 2 percent. 

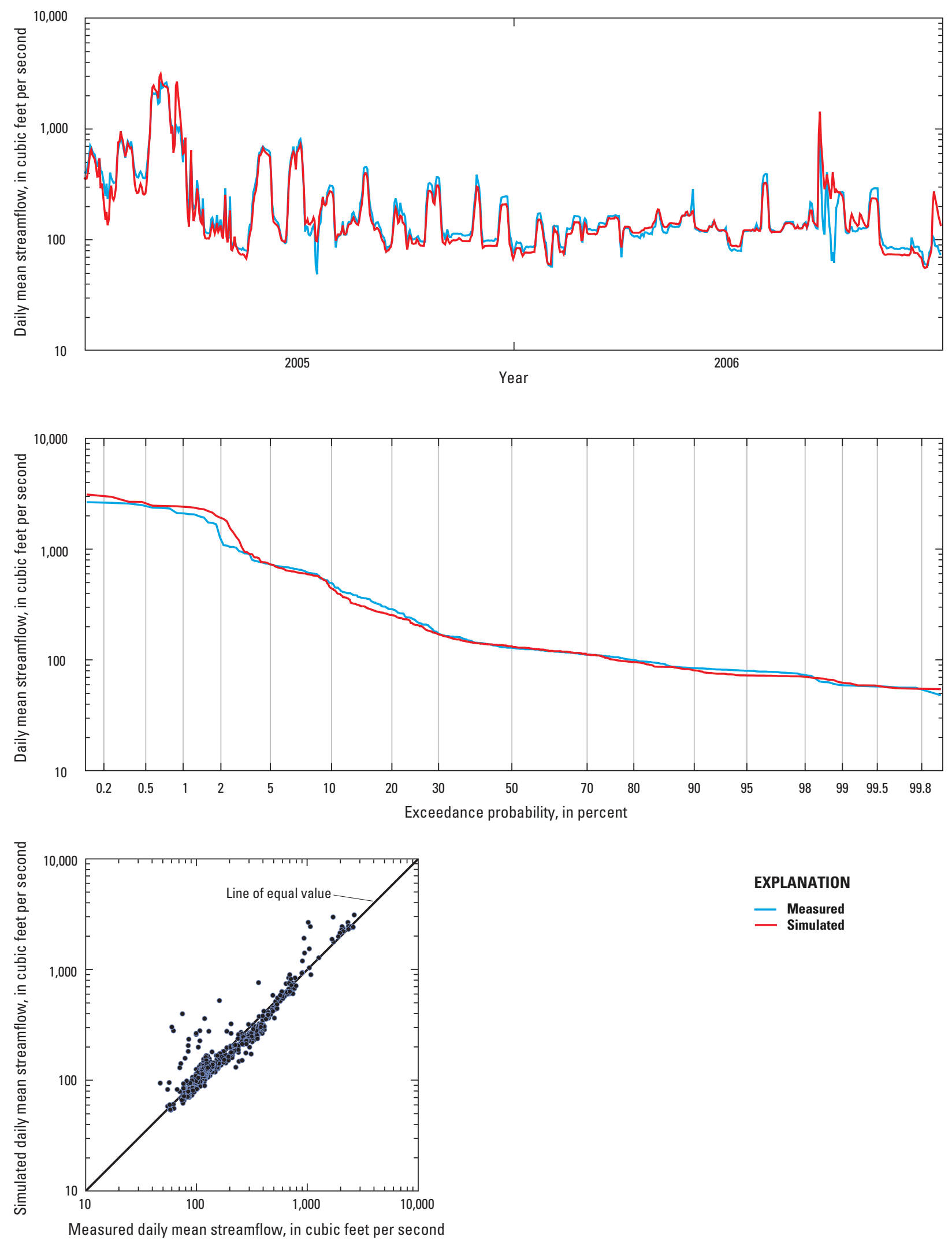

EXPLANATION

- Simulated

Figure 11. Measured and simulated daily mean streamflow at U.S. Geoloical Survey streamflow-gaging station 08211000 Nueces River at Bluntzer, Texas, 2005-6. 
Table 5. Streamflow calibration and testing results for the lower Nueces River watershed model, south Texas.

[acre-ft, acre-feet; $\mathrm{ft}^{3} \mathrm{~s}$, cubic feet per second]

08211200 Nueces River at Bluntzer, Texas

Testing period 2005-6

\begin{tabular}{|c|c|c|c|c|}
\hline Streamflow volumes and peaks & Measured & Simulated & $\begin{array}{c}\text { Error }^{1} \\
\text { (percent) }\end{array}$ & $\begin{array}{c}\text { Criteria }^{2} \\
\text { (percent) }\end{array}$ \\
\hline Total flow volume (acre-ft) & 353,000 & 357,000 & 1.1 & 10 \\
\hline Highest 10-percent daily flows (acre-ft) & 151,000 & 166,000 & 9.9 & 10 \\
\hline Lowest 50-percent daily flows (acre-ft) & 72,800 & 71,600 & -1.6 & 10 \\
\hline Number of years, months, days, or hours & 2 & 24 & 730 & 17,520 \\
\hline Coefficient of determination $\left(\mathrm{R}^{2}\right)$ & 1.00 & 0.98 & 0.92 & 0.91 \\
\hline Nash-Sutcliffe coefficient of model-fit efficiency (NSE) & 1.00 & 0.97 & 0.91 & 0.90 \\
\hline Mean absolute error $\left(\mathrm{ft}^{3} / \mathrm{s}\right)$ & 4.5 & 30.7 & 38.4 & 38.4 \\
\hline Root mean square error $\left(\mathrm{ft}^{3} / \mathrm{s}\right)$ & 5.3 & 57.0 & 117 & 124 \\
\hline
\end{tabular}

08211500 Nueces River at Calallen, Texas

Calibration period 2005-8

\begin{tabular}{|c|c|c|c|c|}
\hline Streamflow volumes and peaks & Measured & Simulated & $\begin{array}{c}\text { Error }^{1} \\
\text { (percent) }\end{array}$ & $\begin{array}{c}\text { Criteria }^{2} \\
\text { (percent) }\end{array}$ \\
\hline Total flow volume (acre-ft) & $1,400,000$ & $1,440,000$ & 2.9 & 10 \\
\hline Highest 10-percent daily flows (acre-ft) & $1,220,000$ & $1,215,000$ & -0.4 & 10 \\
\hline Lowest 50-percent daily flows (acre-ft) & 25,400 & 25,100 & -1.2 & 10 \\
\hline Coefficient of determination $\left(\mathrm{R}^{2}\right)$ & 1.00 & 1.00 & 0.95 & 0.95 \\
\hline Nash-Sutcliffe coefficient of model-fit efficiency (NSE) & 1.00 & 0.99 & 0.93 & 0.92 \\
\hline Mean absolute error $\left(\mathrm{ft}^{3} / \mathrm{s}\right)$ & 37 & 66 & 127 & 130 \\
\hline Root mean square error $\left(\mathrm{ft}^{3} / \mathrm{s}\right)$ & 39 & 152 & 510 & 523 \\
\hline
\end{tabular}

08211500 Nueces River at Calallen, Texas

Testing period 2001-4

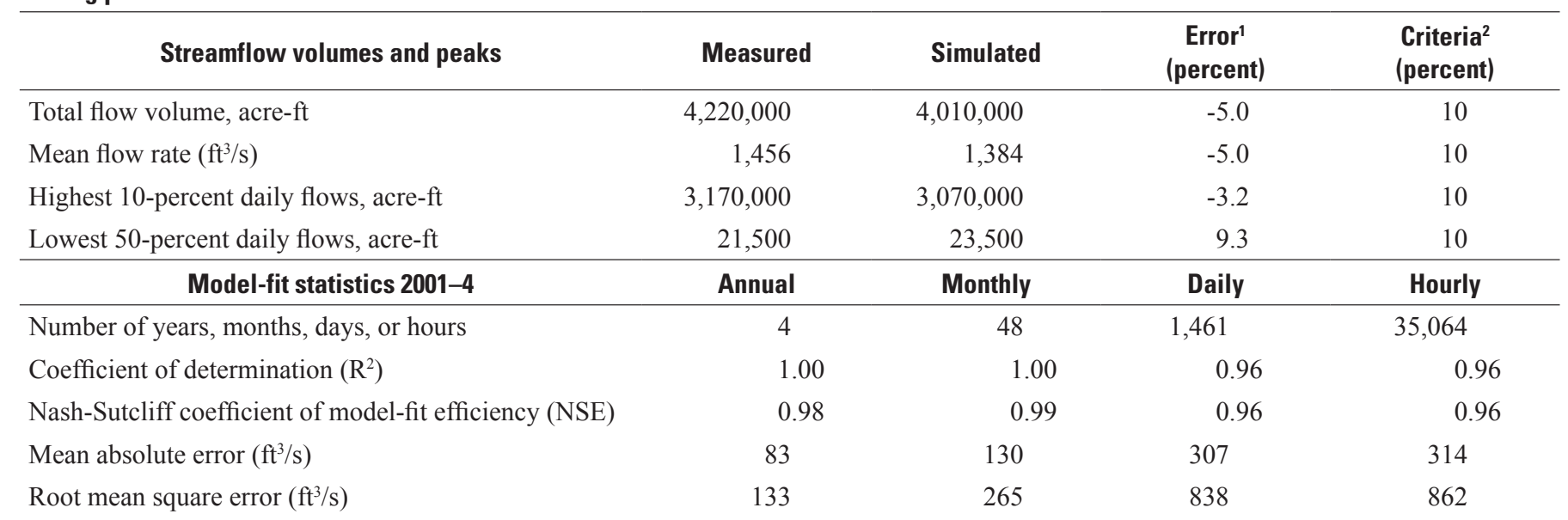


Table 5. Streamflow calibration and testing results for the lower Nueces River watershed model, south Texas-Continued.

[acre-ft, acre-feet; $\mathrm{ft}^{3} \mathrm{~s}$, cubic feet per second]

08211500 Nueces River at Calallen, Texas

Simulation period 2009-10

\begin{tabular}{|c|c|c|c|c|}
\hline Streamflow volumes and peaks & Measured & Simulated & $\begin{array}{c}\text { Error }^{1} \\
\text { (percent) }\end{array}$ & $\begin{array}{c}\text { Criteria }^{2} \\
\text { (percent) }\end{array}$ \\
\hline Total flow volume, acre-ft & 109,000 & 119,000 & 9.2 & 10 \\
\hline Highest 10-percent daily flows, acre-ft & 87,100 & 86,600 & -0.6 & 10 \\
\hline Lowest 50-percent daily flows, acre-ft & 606 & 709 & 17 & 10 \\
\hline Number of years, months, days, or hours & 2 & 24 & 730 & 17,520 \\
\hline Coefficient of determination $\left(\mathrm{R}^{2}\right)$ & 1.00 & 0.98 & 0.85 & 0.83 \\
\hline Nash-Sutcliff coefficient of model-fit efficiency (NSE) & 0.99 & 0.98 & 0.84 & 0.82 \\
\hline
\end{tabular}

08211500 Nueces River at Calallen, Texas

Entire calibration and testing period 2001-10

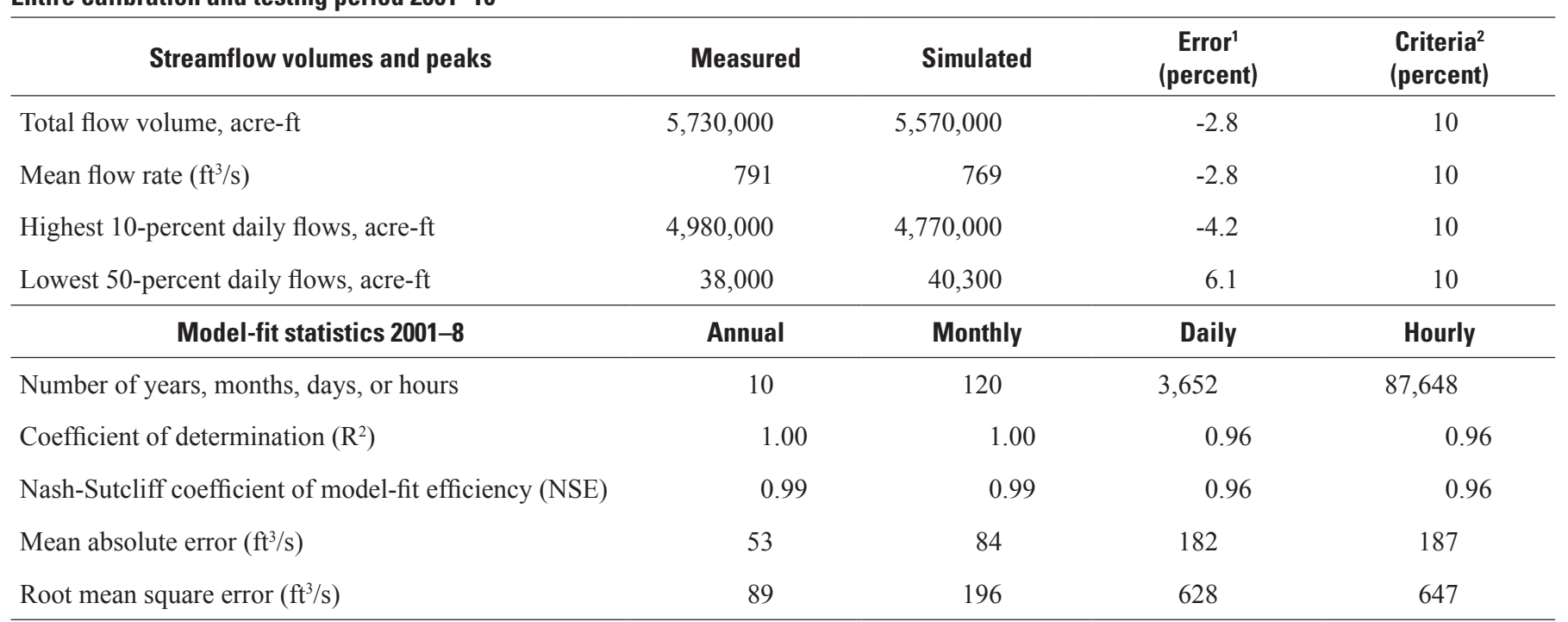

${ }^{1}$ Error is [(simulated-measured)/measured] $\times 100$.

${ }^{2}$ Default error criteria from HSPEXP (Lumb and others, 1994).

The Calallen gage was operated as a partial-record station during 1989-2000; daily streamflows were not reported when instantaneous streamflow exceeded $2,750 \mathrm{ft}^{3} / \mathrm{s}$ because of difficulty measuring higher streamflows at this gage.

A complete record of streamflow for the Calallen gage is available for 2001-10. In June 2000, the Calallen gage was moved about 0.4 mile downstream to its present location and was converted to a continuous streamflow-gaging station capable of measuring the full range of streamflow. Streamflow data measured during 2005-8 at the Calallen gage were used to calibrate the model, and streamflow data from $2001-4$ and 2009-10 were used to test the calibrated model. Streamflow calibration and testing results for the Calallen gage (fig. 12; table 5) indicate very good agreement between measured and simulated streamflow volumes. The error in total simulated streamflow volume at the Calallen gage compared with measured streamflow volume during the calibration period (2005-8) is less than 3 percent; for the 2001-4 testing period, the error in total simulated streamflow volume compared with measured streamflow volume is -5 percent; for the 2009-10 

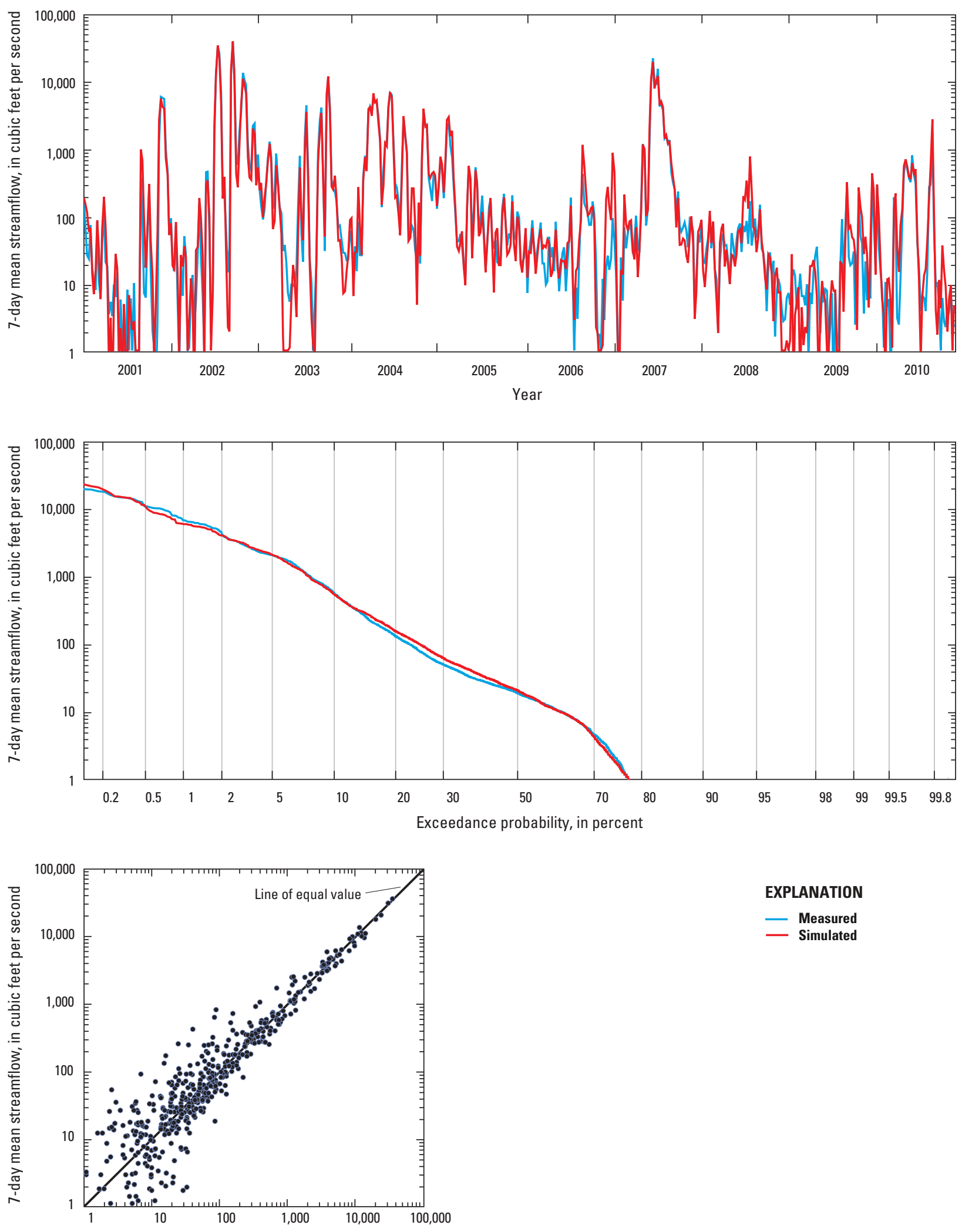

EXPLANATION

- Measured

- Simulated

Measured 7-day mean streamflow, in cubic feet per second

Figure 12. Measured and simulated 7-day mean streamflow at U.S. Geoloical Survey streamflow-gaging station 08211500 Nueces River at Calallen, Texas, 2001-10. 
testing period, the error in total simulated streamflow volume compared with measured streamflow volume was 9.2 percent. For the entire 2001-10 calibration and testing period, the error in total simulated streamflow volume was -2.8 percent.

Using evaluation criteria by Donigian and others (1984), calibration and testing results for streamflow volumes at both the Bluntzer (testing only) and Calallen gages (table 5) were considered very good. The $\mathrm{R}^{2}$ and NSE values were considered acceptable for annual, monthly, daily, and hourly statistics. The NSE for hourly streamflows ranged from 0.82 to 0.96 for the calibration and testing periods at the Bluntzer and Calallen gages. The minimum NSE values for both stations for daily, monthly, and annual simulations were $0.84,0.97$, and 0.98 , respectively (table 5).

\section{Suspended Sediment}

Suspended-sediment concentrations and loads were simulated using the appropriate HSPF modules: SEDMNT for simulation of production and removal of sediment from PERLNDs, SOLIDS for simulation of accumulation and removal of solids from IMPLNDs, and SEDiment TRaNsport (SEDTRN) for simulation of transport of sediment in RCHRES. For each PERLND, the processes of detachment of sediment from the soil matrix and washoff of this sediment were simulated on the basis of rainfall intensity, surface runoff, and model parameters that control the accumulation, detachment, and transport of soils. For each IMPLND, the processes of accumulation and washoff of sediment are based on the amount of sediment available and the transport capacity of the overland flow. Sediment transport processes in RCHRES included deposition and scour, which are functions of sediment size, settling velocity, density, erodibility, bed depth, and critical shear stress. RCHRES sediment transport is computed separately for each sand, silt, and clay fraction of sediment size.

Selection of initial values and calibration of sedimentrelated process parameters of the SEDMNT, SOLIDS, and SEDTRN modules (appendix 1) were based on published guidelines (Donigian and Love, 2003; U.S. Environmental Protection Agency, 2006). Calibration of sediment-related parameters involved the following steps: (1) estimation of suspended-sediment loads carried in flows released from Lake Corpus Christi; (2) identification of reasonable sediment yields from the various land types in the watershed; (3) estimation of the soil-erosion and sediment-washoff parameters used to generate sediment washoff from PERLNDs and IMPLNDs, respectively; and (4) calibration of sedimenttransport (RCHRES) parameters by comparison of measured and simulated suspended-sediment concentrations and loads at the streamflow-gaging stations.

\section{Estimation of Suspended-Sediment Loads from Lake Corpus Christi}

Estimation of suspended-sediment loads in releases from Wesley E. Seale Dam (Lake Corpus Christi) were based on 14 reported suspended-sediment loads during 1964-71 (table 2) and 9 suspended-sediment samples collected by the USGS during 2006-7, 2010 (table 3). All suspendedsediment data (historical and recent) were collected at the Mathis gage downstream from Wesley E. Seale Dam. These data represented streamflow ranging from 72 to $35,129 \mathrm{ft}^{3} / \mathrm{s}$ and corresponding suspended-sediment loading rates ranging from 4.3 to 8,872 tons/d. Data collected during 1964-71 represented mean streamflow and suspended-sediment loads during relatively large releases that lasted days or weeks. Data collected during 2006-7 represented instantaneous conditions (a typical suspended-sediment sample was collected during a period of about 1 hour). A least-squares regression equation (fig. 13) was developed by relating daily mean discharge at the Mathis gage and daily sediment load. Discharge and sediment loads were log-transformed before performing the regression to improve the quality of the regression fit, then retransformed to original units (Helsel and Hirsch, 2002). The resulting equation was

$$
L=0.026 \times Q^{1.195}
$$

where

$$
\begin{aligned}
& L \quad \text { is suspended-sediment load, in tons per day; } \\
& \text { and } \\
& \text { is daily mean discharge, in cubic feet per } \\
& \text { second. }
\end{aligned}
$$

The $\mathrm{R}^{2}$ for the regression equation was 0.94 ; the standard error of the residuals (RSE), a measure of the dispersion of the data around the regression line (Helsel and Hirsch, 2002, p. 244), was 625 tons/d. The residual plot (fig. 13) shows the regression residuals (as a percentage of the measured suspended-sediment load) plotted as a function of the measured suspended-sediment load. The distribution of the error residuals was relatively uniform, indicating a reasonable regression model.

A comparison of model-simulated input of suspendedsediment loads with suspended-sediment loads computed from nine samples collected at the Mathis gage during 2006-7 and 2010 is listed in table 6 . These results are not considered a calibration but rather a test of the ability of the regression equation (equation 2) to reasonably simulate instantaneous suspended-sediment concentrations and loads entering the study area through releases from Wesley E. Seale Dam. In general, measured and simulated suspended-sediment loads compare favorably. Regression-equation derived sediment loads were within 37 percent of measured loads for all samples except for the sample collected on November 20, 2006, for which the simulated load was 116 percent of the measured load (table 6). The November 20, 2006, sample was collected during a period of low flow and represented a relatively small sediment load compared with the relatively high flows that were mostly sampled at this site. Therefore, the loads computed by the regression equation were considered reasonable estimates of the total suspended-sediment loads that were discharged from Wesley E. Seale Dam. 

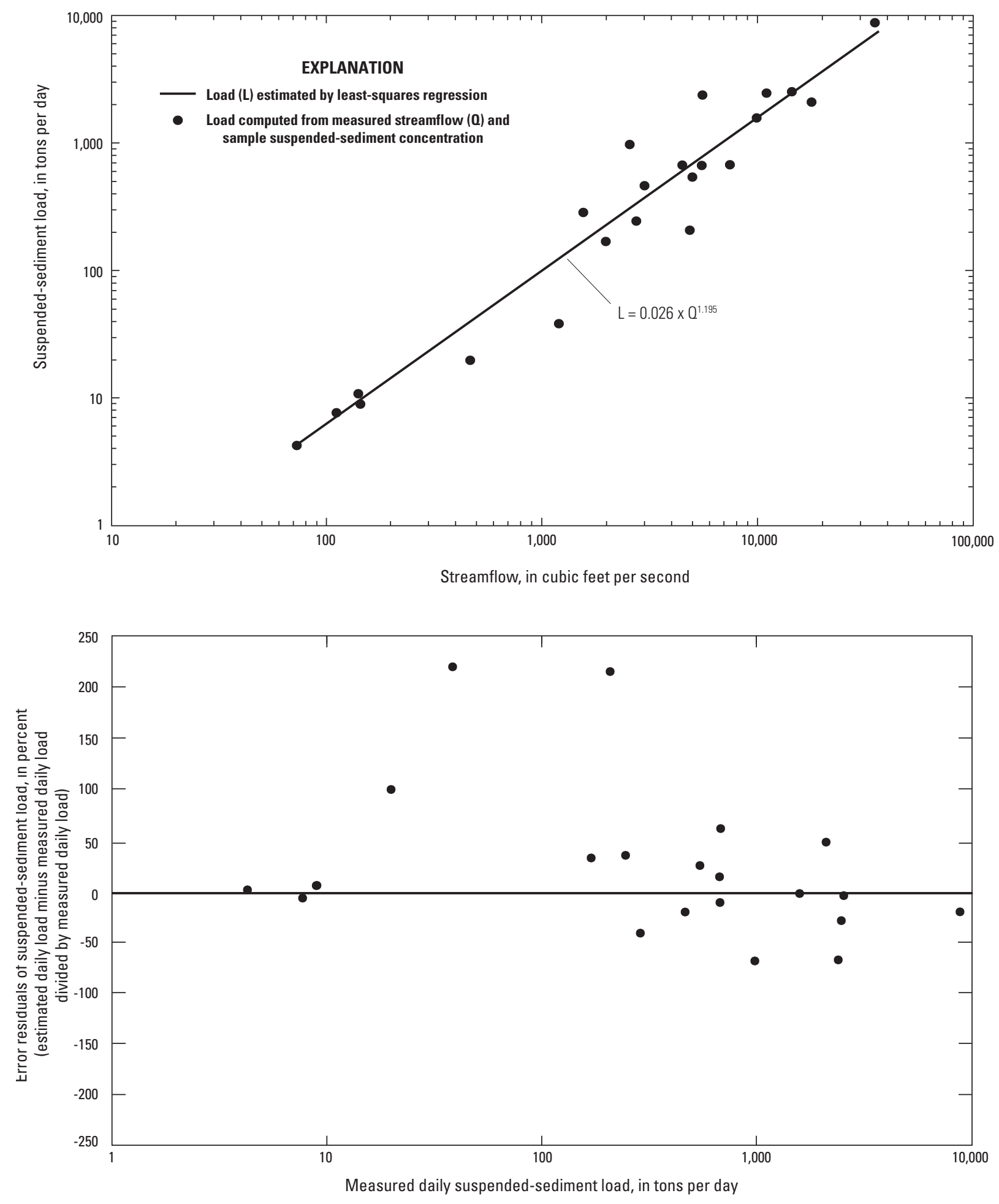

Figure 13. Relation between streamflow and suspended-sediment load and plot of regression error residuals based on 22 streamflowload data pairs from 08211000 Nueces River near Mathis, Texas, 1964-71 and 2006-7. 
Table 6. Measured and simulated streamflows, measured suspended-sediment particle size, and measured and simulated suspendedsediment concentrations and loads for selected sampling events at 08211000 Nueces River near Mathis, Texas, $2006-7,2010$.

[ $\mathrm{ft}^{3} / \mathrm{s}$, cubic feet per second; $\mathrm{mm}$, millimeters; $\mathrm{mg} / \mathrm{L}$, milligrams per liter; $\mathrm{mm}$, millimeters; tons/day, tons per day]

\begin{tabular}{|c|c|c|c|c|c|c|c|c|}
\hline May 17, 2006 & 139 & 137 & 98 & 24 & 28 & 8.9 & 10 & 12 \\
\hline Sept. 5, 2006 & 138 & 136 & 99 & 24 & 28 & 8.7 & 10 & 15 \\
\hline Nov. 20, 2006 & 72 & 71 & 94 & 22 & 48 & 4.3 & 9.3 & 116 \\
\hline May 26, 2007 & 461 & 511 & 99 & 16 & 12 & 21 & 17 & -19 \\
\hline May 29, 2007 & 1,190 & 1,270 & 98 & 12 & 11 & 39 & 35 & -10 \\
\hline Sept. 7, 2010 & 115 & 116 & 64 & 38 & 25 & 12 & 7.6 & -37 \\
\hline
\end{tabular}

${ }^{1}$ Percent by weight of sediment sample that passes through a 0.0625 millimeter sieve.

${ }^{2}$ Error is [(simulated load-measured load)/measured load $] \times 100$.

The time series of sediment loads from Lake Corpus Christi were apportioned between clay and silt particle sizes and input to the model in RCHRES 4 (as was done with flows from Wesley E. Seale Dam). An apportionment of 40 percent silt and 60 percent clay was done on the basis of literature synthesis work by White and Calnan (1990).

Several studies of sediment yields (pounds per acre per year [lbs/acre/yr] or tons per acre per year [tons/acre/yr]) from specific land-use types and land covers have been made for the south Texas area (Baird and others, 1996; Ockerman and Petri, 2001; Ockerman, 2002; Ockerman and Fernandez, 2010). These studies provided data for sediment yields for cropland, rangeland (grassland/pasture and shrub/scrub), and developed land. Data and analyses from these studies were compared with simulated sediment yields from similar land type PERLNDs. Sediment-related parameters for PERLNDs were adjusted so that simulated sediment yields compared reasonably with field data results.

Ockerman and Petri (2001, p. 19), in a study of five cropland watersheds in Nueces and Kleberg Counties, reported an average sediment yield of $610 \mathrm{lbs} /$ acre/yr during 1996-98. Ockerman and Fernandez (2010, p. 20), in a study of two primarily cropland watersheds in the Oso Creek watershed in Nueces County, reported average sediment runoff yields of 139 and $522 \mathrm{lbs} /$ acre/yr during 2005-8. In a study of sediment runoff from two rangeland study sites in San Patricio County, Ockerman (2002) reported an average sediment yield of $28 \mathrm{lbs} /$ acre/yr during 2000-1.
Estimates of suspended-solids concentrations in runoff from developed land uses and land covers were compiled for the south Texas area in a study by Baird and others (1996). Median event-mean concentrations for residential, commercial, industrial, and transportation land uses were compiled from a literature review. These event-mean concentrations were used to develop estimates of sediment loads in the Oso Creek watershed for 1989-93. The average sediment yield for developed land (including residential, commercial, industrial, and transportation land uses) was $52 \mathrm{lbs} / \mathrm{acre} / \mathrm{yr}$ (Baird and others, 1996, p. 199-218). A comparison of sediment yields for selected land-use/landcover types is listed in table 7. The yields from the literature review were used as calibration target values for model simulations. For comparison, table 7 also lists HSPF-simulated sediment yields for selected land uses and land covers for 1989-2008 in the lower Nueces River watershed (Ockerman and Heitmuller, 2010). HSPF parameter values related to sediment production (sediment detachment and washoff process) were iteratively adjusted until simulated yields approximated the target yields determined from the literature review.

Annual sediment yields simulated for cropland varied from 200 to $530 \mathrm{lbs} / \mathrm{acre} / \mathrm{yr}$ depending on crop, soil type, and rainfall. Annual sediment yields simulated for rangeland were 39 to $55 \mathrm{lbs} / \mathrm{acre} / \mathrm{yr}$, developed land were 38 to $75 \mathrm{lbs} /$ acre/yr, and open/undeveloped land were 120 to $340 \mathrm{lbs} / \mathrm{acre} /$ yr. Sediment yields simulated using NWS rainfall data from 
Table 7. Comparison of literature estimates and simulation results for sediment yields from selected land-cover and land-use types in the coastal area of south Texas and the lower Nueces River watershed.

$[--$, not applicable $]$

\begin{tabular}{|c|c|c|}
\hline $\begin{array}{l}\text { Land-cover/ } \\
\text { land-use type }\end{array}$ & $\begin{array}{l}\text { Sediment yield estimate } \\
\text { from literature } \\
\text { (pounds per } \\
\text { acre per year) } \\
\text { and reference }\end{array}$ & $\begin{array}{l}\text { Average } \\
\text { 1989-2008 } \\
\text { simulated } \\
\text { sediment yield' }{ }^{1} \\
\text { (pounds per } \\
\text { acre per year) }\end{array}$ \\
\hline Cropland & $\begin{array}{l}610 \text { (Ockerman and } \\
\text { Petri, 2001); } 139 \text { and } \\
522(\text { Ockerman and } \\
\text { Fernandez, 2010) }\end{array}$ & $200-530$ \\
\hline $\begin{array}{l}\text { Rangeland (pasture, } \\
\text { shrub, grassland) }\end{array}$ & 28 (Ockerman, 2002) & $39-55$ \\
\hline $\begin{array}{l}\text { Developed (commercial, } \\
\text { transportation, } \\
\text { residential, industrial) }\end{array}$ & $\begin{array}{l}52 \text { (Baird and others, } \\
\text { 1996) }\end{array}$ & $38-75$ \\
\hline Open/undeveloped & -- & $120-340$ \\
\hline
\end{tabular}

${ }^{1}$ Ockerman and Heitmuller, 2010.

Robstown were larger for all land types than sediment yields simulated using NWS rainfall data from Mathis. The main reason for differences in sediment yields were differences in the amount of rainfall measured during 2000-8 at the NWS stations for the two parts of the study area; average annual rainfall amounts recorded by the NWS during 2000-8 were 34.1 in. at Robstown and 26.8 in. at Mathis.

\section{Model Calibration}

For parameters related to sediment erosion from various land types, model calibration and testing were based on available studies and data collected during 1989-2010. Therefore, calibration of PERLND parameters was based on simulations from the same period, 1989-2010. Model calibration of RCHRES suspended-sediment processes was based primarily on data collected at the Bluntzer and Calallen gages during 2006-7. These data were used to develop estimates of suspended-sediment loads for 2001-8, which were then compared with model simulation results.

Downstream from Lake Corpus Christi, at the Bluntzer and Calallen gages, suspended-sediment concentrations and loads in streams were calibrated to available suspendedsediment data collected by the USGS during 2006-7. RCHRES parameters related to sediment transport were adjusted (calibrated) to minimize the differences between measured and simulated sediment concentrations and computed (from measured concentrations and measured streamflows) and simulated loads. Instream transport and concentrations of sand are simulated by power functions that relate sand concentration to average RCHRES stream velocity. The power functions are calibrated by user-selected coefficients and exponents for each RCHRES. Proceeding in downstream order, the calibration process to determine suspended-sediment concentrations and loads was repeated for each RCHRES in the intervening areas between sedimentsampling stations. Suspended-sediment calibration results at the Bluntzer gage are listed in table 8 . Table 8 also lists measured and simulated suspended-sediment concentrations and measured (computed) and simulated loads from 14 samples collected during 2006-7, 2010. Errors in simulated suspended-sediment loads at the Bluntzer gage (table 8) generally were larger compared with those at the Mathis gage (table 6), mostly because of differences in the amount of error associated with the simulation of streamflow. Overall, the amount of error associated with the simulation of streamflow at the Bluntzer gage was larger than the amount of error associated with the simulation of streamflow at the Mathis gage.

Although simulation errors for instantaneous or daily suspended-sediment loads were at times relatively large (197 percent for the September 7, 2010, sample; table 8), simulation errors for longer periods (for example, monthly or yearly) were deemed acceptable. The percentage error of the sum of simulated sediment loads for all 14 samples (12,620 tons/d), compared with the sum of the measured (computed) sediment loads for all 14 samples (10,960 tons/d) was 15 percent.

Suspended-sediment data were available for 10 suspended-sediment samples collected at the Calallen gage during 2006-7. By using these data, suspended-sediment loads were computed from daily mean streamflows and measured suspended-sediment concentrations. Similar to the approach used to estimate sediment loads from Lake Corpus Christi (fig. 13), the computed loads at Calallen were used to develop a regression equation to relate daily suspended-sediment loads to daily mean streamflow (fig. 14). The resulting equation was

$$
L=0.119 \times Q^{1.061}
$$

where

$$
\begin{aligned}
& L \quad \begin{array}{l}
\text { is suspended-sediment load, in tons per day; } \\
\text { and }
\end{array} \\
& Q \quad \begin{array}{l}
\text { is daily mean discharge, in cubic feet per } \\
\text { second. }
\end{array}
\end{aligned}
$$

$\mathrm{R}^{2}$ for the regression equation was 0.87 ; RSE was 427 pounds per day. The residual plot on figure 14 shows regression residuals (as a percentage of the measured suspended-sediment load) plotted as a function of the measured suspended-sediment load. The distribution of the error residuals was relatively uniform, indicating a reasonable regression model.

The regression equation was then used to estimate suspended-sediment loads during 2001-8. The estimated daily suspended-sediment load computed using measured streamflow and sediment data was used as a calibration target to compare with simulated suspended-sediment loads at Calallen. Model sediment-transport parameter values for RCHRESs downstream from the Calallen gage were adjusted on the basis of this comparison. 
Table 8. Measured and simulated streamflows, measured suspended-sediment particle size, and measured and simulated suspendedsediment concentrations and loads for selected suspended-sediment sampling events at 08211200 Nueces River at Bluntzer, Texas, 2006-7, 2010.

[ft $/ \mathrm{s}$, cubic feet per second; mm, millimeters; $\mathrm{mg} / \mathrm{L}$, milligrams per liter; tons/day, tons per day]

\begin{tabular}{|c|c|c|c|c|c|c|c|c|}
\hline Sample date & $\begin{array}{c}\text { Measured } \\
\text { streamflow } \\
\left(\mathrm{ft}^{3} / \mathrm{s}\right)\end{array}$ & $\begin{array}{c}\text { Simulated } \\
\text { streamflow } \\
\left(\mathrm{ft}^{3} / \mathrm{s}\right)\end{array}$ & $\begin{array}{c}\text { Measured } \\
\text { sediment particle } \\
\text { diameter less } \\
\text { than } 0.0625 \mathrm{~mm} \\
\text { (percent) }^{1} \\
\end{array}$ & $\begin{array}{c}\text { Measured } \\
\text { suspended- } \\
\text { sediment } \\
\text { concentration } \\
\text { (mg/L) } \\
\end{array}$ & $\begin{array}{c}\text { Simulated } \\
\text { suspended- } \\
\text { sediment } \\
\text { concentration } \\
\text { (mg/L) }\end{array}$ & $\begin{array}{c}\text { Measured } \\
\text { suspended- } \\
\text { sediment } \\
\text { load } \\
\text { (tons/day) } \\
\end{array}$ & $\begin{array}{c}\text { Simulated } \\
\text { suspended- } \\
\text { sediment } \\
\text { load } \\
\text { (tons/day) }\end{array}$ & $\begin{array}{c}\text { Error in } \\
\text { suspended- } \\
\text { sediment load } \\
\text { (percent) })^{2}\end{array}$ \\
\hline May 17, 2006 & 121 & 136 & 97 & 48 & 22 & 16 & 8.3 & -48 \\
\hline July 20, 2006 & 116 & 118 & 88 & 51 & 25 & 16 & 7.9 & -51 \\
\hline Sept. 5, 2006 & 136 & 129 & 97 & 52 & 23 & 19 & 8.1 & -57 \\
\hline Sept. 19, 2006 & 1,050 & 1,370 & 97 & 1,070 & 468 & 3,030 & 1,730 & -43 \\
\hline Nov. 20, 2006 & 82 & 71 & 89 & 25 & 35 & 5.5 & 6.8 & 24 \\
\hline Jan. 4, 2007 & 153 & 344 & 81 & 293 & 344 & 121 & 238 & 97 \\
\hline Jan. 25, 2007 & 243 & 970 & 99 & 760 & 455 & 498 & 1,190 & 139 \\
\hline May 26, 2007 & 471 & 405 & 100 & 94 & 38 & 119 & 41 & -66 \\
\hline May 29, 2007 & 1,330 & 1,170 & 97 & 54 & 44 & 194 & 140 & -28 \\
\hline July 1, 2007 & 5,980 & 6,290 & 92 & 45 & 33 & 726 & 553 & -24 \\
\hline July 11, 2007 & 15,000 & 14,400 & 79 & 40 & 64 & 1,620 & 2,500 & 54 \\
\hline Sept. 7, 2010 & 160 & 197 & 78 & 78 & 306 & 34 & 101 & 197 \\
\hline Sept. 19, 2010 & 1,500 & 3,640 & 85 & 540 & 402 & 2,190 & 4,200 & 92 \\
\hline Sept. 20, 2010 & 4,270 & 3,060 & 94 & 206 & 226 & 2,370 & 1,900 & -20 \\
\hline
\end{tabular}

${ }^{1}$ Percent by weight of sediment sample that passes through a 0.0625 millimeter sieve.

${ }^{2}$ Error is [(simulated load-measured load $) /$ measured load $] \times 100$.

Calibration results for the Calallen gage (table 9) include a comparison of the average monthly streamflow volumes and suspended-sediment loads simulated using the HSPF model with the average monthly streamflow volumes measured at the gage and average monthly suspended-sediment loads estimated using equation 3. Table 9 lists the annual, monthly, and daily model-fit statistics for 2001-8. During 2001-8, average monthly suspended-sediment loads at the Calallen gage were undersimulated by 4.2 percent (table 9) compared with the loads estimated by regression (equation 3 ). Model-fit statistics indicated the model simulates daily, monthly, and annual sediment loads reasonably well. The NSE was 0.80 for daily simulations, increasing to 0.95 and 0.97 for simulation of monthly and annual, respectively, suspended-sediment loads (table 9).

Suspended-sediment calibration results for individual samples collected at the Calallen gage are listed in table 10. Table 10 compares simulated suspended-sediment concentrations and loads with estimated suspended-sediment concentrations and loads computed from measured streamflow and suspended-sediment concentrations obtained from 11 samples collected during 2006-7, and 2010. Similar to comparison of measured and simulated loads for individual samples collected at the Bluntzer gage, simulation errors for instantaneous suspended-sediment loads were at times relatively large, simulation errors for longer periods (for example, monthly or yearly) were deemed acceptable. The percent error of the sum of simulated sediment loads for all 11 samples (12,370 tons/d), compared with the sum of the measured (computed) sediment loads for all 11 samples $(11,720$ tons/d) was 5.5 percent.

Donigian and others (1984) present general guidelines for characterizing HSPF sediment calibrations, similar to the guidelines for streamflow calibration. For annual and monthly sediment loads, model calibration is considered very good when the error is less than 15 percent, good when the error is 15-25 percent, and fair when the error is $25-35$ percent. By these guidelines, calibration results for the sum of simulated suspended-sediment loads at the Calallen gage (table 10) are considered very good. The $\mathrm{R}^{2}$ and NSE values were considered acceptable for annual, monthly, and daily statistics (table 9). 

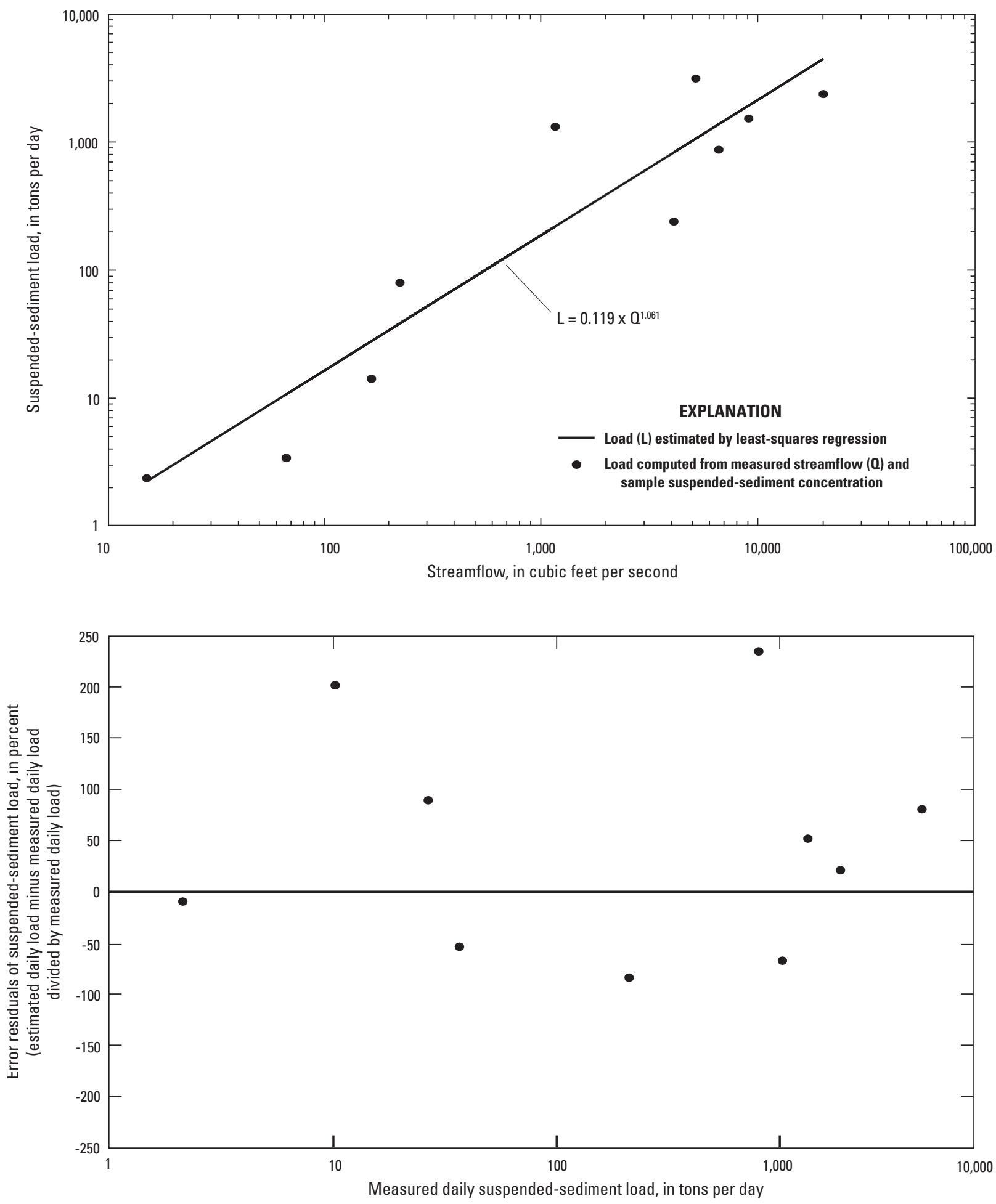

Figure 14. Relation between streamflow and suspended-sediment load and plot of regression error residuals based on 10 streamflowload data pairs from 08211500 Nueces River at Calallen, Texas, 2006-7. 
Table 9. Suspended-sediment calibration results for the Hydrological Simulation Program—FORTRAN model of the lower Nueces River watershed, south Texas, 2001-8.

\section{Nueces River at Calallen, Texas}

\begin{tabular}{|c|c|c|c|}
\hline $\begin{array}{l}\text { Average monthly streamflow volumes } \\
\text { and suspended-sediment loads }\end{array}$ & $\begin{array}{l}\text { Measured/ } \\
\text { estimated }^{1}\end{array}$ & Simulated & $\begin{array}{c}\text { Error }^{2} \\
\text { (percent) }\end{array}$ \\
\hline Flow volume (acre-feet) & 58,500 & 56,400 & -3.6 \\
\hline Coefficient of determination $\left(\mathrm{R}^{2}\right)$ & 0.98 & 0.96 & 0.82 \\
\hline Nash-Sutcliff coefficient of model-fit efficiency (NSE) & 0.97 & 0.95 & 0.80 \\
\hline Mean absolute error (tons) & 12,200 & 1,640 & 84.4 \\
\hline Percent mean absolute error (percent) & 17.1 & 27.8 & 43.4 \\
\hline
\end{tabular}

${ }^{1}$ Streamflow volumes at 08211500 Nueces River at Calallen, Tex., are measured values. Suspended-suspended loads are estimated by regression of measured streamflow and suspended-sediment loads calculated from streamflow and measured suspended-sediment concentrations for 10 sampling events during $2006-7$.

${ }^{2}$ Error is $[($ simulated-measured/measured $)] \times 100$.

Table 10. Measured and simulated streamflows, measured suspended-sediment particle size, and measured and simulated suspended-sediment concentrations and loads, for selected sampling events at 08211500 Nueces River near Calallen, Texas, 2006-7, 2010.

$\left[\mathrm{ft}^{3} / \mathrm{s}\right.$, cubic feet per second; $\mathrm{mm}$, millimeters; $\mathrm{mg} / \mathrm{L}$, milligrams per liter; tons/day, tons per day]

\begin{tabular}{|c|c|c|c|c|c|c|c|c|}
\hline Sample date & $\begin{array}{c}\text { Measured } \\
\text { streamflow } \\
\left(\mathrm{ft}^{3} / \mathrm{s}\right)\end{array}$ & $\begin{array}{c}\text { Simulated } \\
\text { streamflow } \\
\left(\mathrm{ft}^{3} / \mathrm{s}\right)\end{array}$ & $\begin{array}{c}\text { Measured } \\
\text { sediment particle } \\
\text { diameter less } \\
\text { than } 0.0625 \mathrm{~mm} \\
\text { (percent) }^{1}\end{array}$ & $\begin{array}{l}\text { Measured } \\
\text { suspended- } \\
\text { sediment } \\
\text { concentration } \\
\text { (mg/L) }\end{array}$ & $\begin{array}{l}\text { Simulated } \\
\text { suspended- } \\
\text { sediment con- } \\
\text { centration } \\
\text { (mg/L) }\end{array}$ & $\begin{array}{l}\text { Measured } \\
\text { suspended- } \\
\text { sediment } \\
\text { load } \\
\text { (tons/day) }\end{array}$ & $\begin{array}{l}\text { Simulated } \\
\text { suspended- } \\
\text { sediment } \\
\text { load } \\
\text { (tons/day) }\end{array}$ & $\begin{array}{l}\text { Error in } \\
\text { suspended- } \\
\text { sediment } \\
\text { load } \\
\text { (percent) }^{2}\end{array}$ \\
\hline May 16, 2006 & 15 & 22 & 82 & 58 & 27 & 2.3 & 1.4 & -39 \\
\hline Sept. 19, 2006 & 1,150 & 1,340 & 100 & 429 & 316 & 1,330 & 992 & -25 \\
\hline Jan. 25, 2007 & 163 & 455 & 89 & 32 & 98 & 14 & 161 & 1,050 \\
\hline Mar. 15, 2007 & 221 & 170 & 32 & 134 & 74 & 80 & 40 & -50 \\
\hline July 2, 2007 & 5,100 & 7,360 & 94 & 231 & 44 & 3,180 & 871 & -73 \\
\hline Aug. 16, 2007 & 4,050 & 4,610 & 94 & 22 & 24 & 241 & 296 & 23 \\
\hline Sept. 20, 2010 & 1,970 & 4,330 & 89 & 381 & 300 & 2,030 & 3,670 & 81 \\
\hline
\end{tabular}

${ }^{1}$ Percent by weight of sediment sample that passes through a 0.0625 millimeter sieve.

${ }^{2}$ Error is [(simulated load-measured load/measured load $\left.)\right] \times 100$. 


\section{Parameter Calibration Values}

Calibration and testing of the HSPF model resulted in a final set of model parameter values for simulation of streamflow and suspended-sediment loads for the study area. Calibrated values (or ranges of values) for selected parameters related to hydrology simulation are listed in table 11, and calibrated values (or ranges of values) for selected sedimentrelated parameters used in the HSPF model are listed in table 12 .

\section{Sensitivity Analysis}

Calibrated values of selected HSPF process-related parameters were further evaluated by doing a sensitivity analysis to determine the effects that changes in the selected parameters would have on simulated streamflow and suspended-sediment loads. Each sensitivity simulation was made by adjusting a single parameter of the model by relatively large amounts (increased by 40 percent) while keeping other model parameters unchanged. The sensitivity analysis model runs were performed for 2001-8. The resulting changes in streamflow and suspended-sediment loads were evaluated at the inflow to RCHRES 97 (fig. 9), which is considered the inflow to the Nueces Estuary. The changes in streamflow and suspended-sediment loads resulting from adjustments of selected parameters are listed in table 13.

Simulated streamflow was relatively insensitive to adjustments of any of the selected parameters. One reason is that most of the streamflow, which is simulated in the model as an input boundary condition, originates as inflow from Lake Corpus Christi releases. In the sensitivity analysis, the parameters that had the largest effects on simulated suspendedsediment loads were the index to infiltration capacity of soil (INFILT), lower-zone nominal storage (LZSN), and coefficient of detached-sediment washoff equation (KSER). Overall, changes in suspended-sediment loads, when these parameters were adjusted, were comparatively small compared with the changes applied to the parameter values. The INFILT parameter had the largest effect on simulated suspendedsediment loads; a 40-percent increase in the INFILT parameter resulted in a 7.1-percent decrease in the simulated suspended-sediment load. For the other parameters examined for sensitivity, increases in parameter values of 40 percent resulted in changes to the simulated suspended-sediment load ranging from -3.2 to 4.9 percent (table 13).

Table 11. Summary of calibrated values for selected hydrologic parameters for the Hydrological Simulation Program—FORTRAN model of the lower Nueces River watershed, south Texas.

[PERLND, pervious land surface; --, none; IMPLND, impervious land surface]

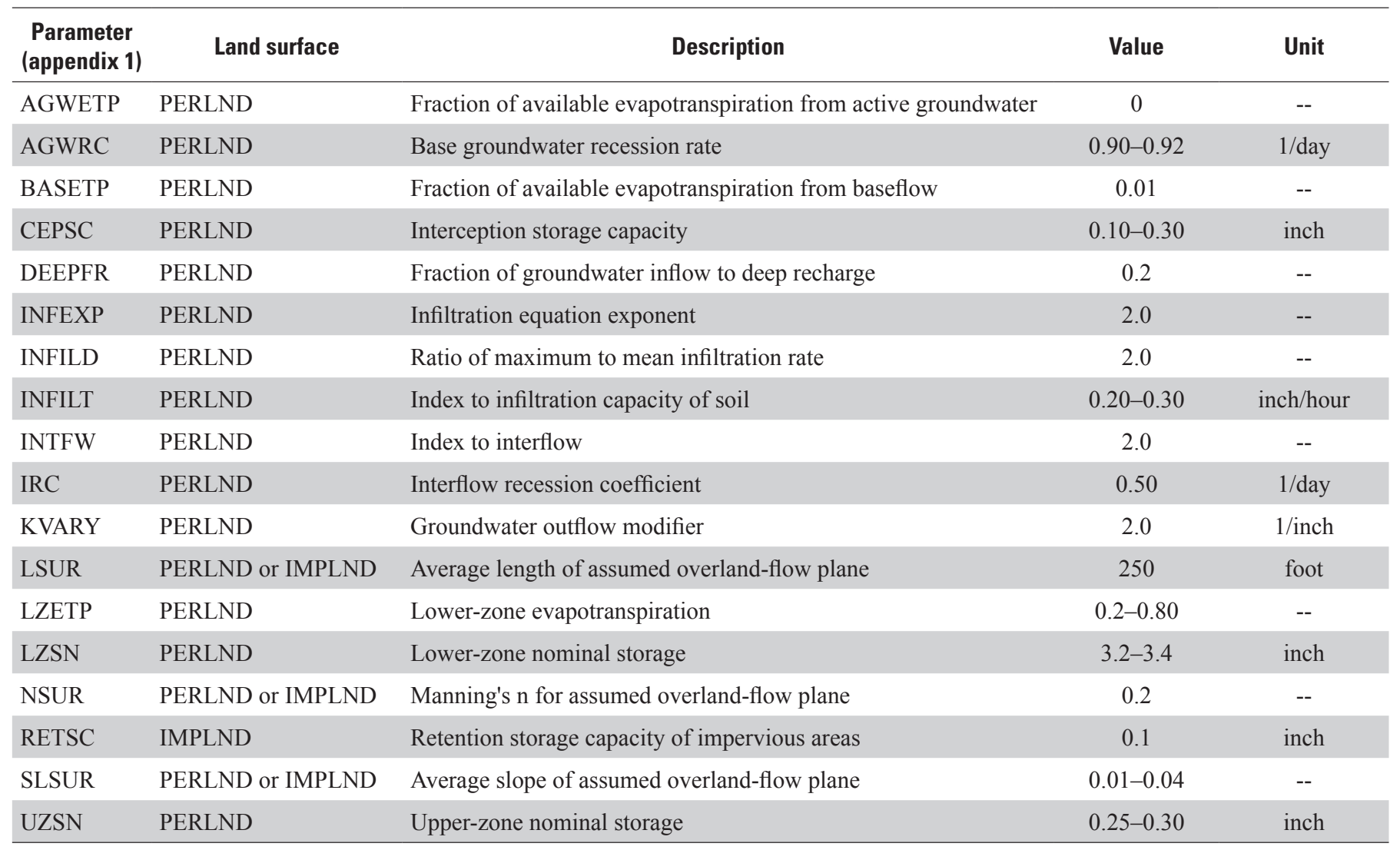


Table 12. Summary of calibrated values for selected sediment-related parameters for the Hydrological Simulation ProgramFORTRAN model of the lower Nueces River watershed, south Texas.

[PERLND, pervious land surface; IMPLND, impervious land surface; RCHRES, stream/reservoir reach]

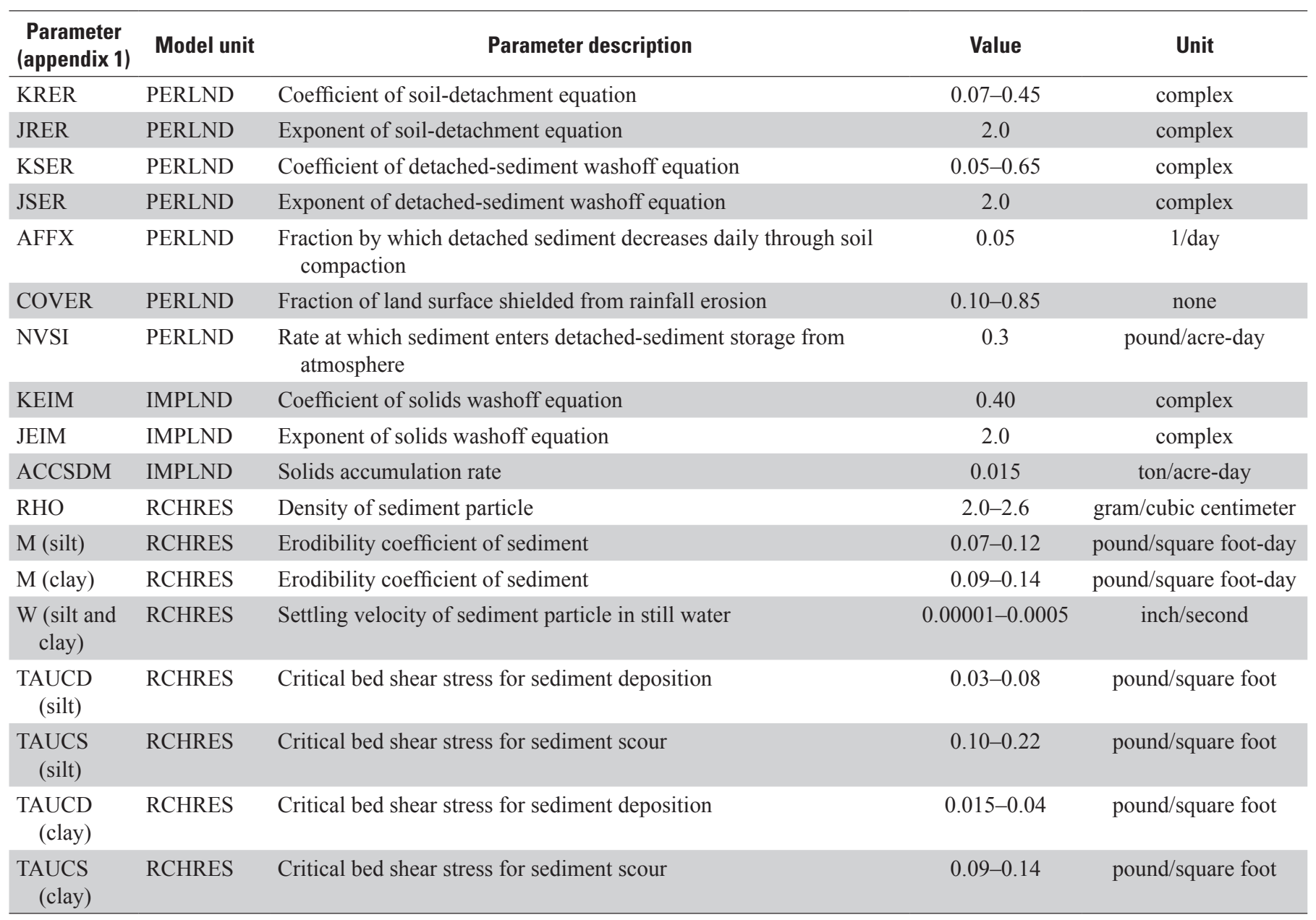

Table 13. Sensitivity of simulated streamflow volumes and suspended-sediment loads to changes in selected process-related parameters for the lower Nueces River watershed model, south Texas.

[DEEPFR, fraction of groundwater inflow to deep recharge; INFILT, index to infiltration capacity of soil; LZSN, lower zone nominal storage; KRER, coefficient of soil-detachment equation; KSER, coefficient of detached-sediment washoff equation; M (silt), erodibility coefficient of silt sediment; M (clay), erodibility coefficient of clay sediment]

\begin{tabular}{lccccc}
\hline $\begin{array}{c}\text { Parameter } \\
\text { (appendix 1) }\end{array}$ & Initial value & Adjusted value & $\begin{array}{c}\text { Change in } \\
\text { parameter value }{ }^{1} \\
\text { (percent) }\end{array}$ & $\begin{array}{c}\text { Change in } \\
\text { streamflow volume' } \\
\text { (percent) }\end{array}$ & $\begin{array}{c}\text { Change in suspended- } \\
\text { sediment load' } \\
\text { (percent) }\end{array}$ \\
\hline DEEPFR & 0.20 & 0.28 & 40 & -0.6 \\
INFILT & $0.20-0.30$ & $0.28-0.42$ & 40 & -0.2 & -0.5 \\
LZSN & $3.20-3.40$ & $4.48-4.76$ & 40 & -1.0 & -7.1 \\
KRER & $0.07-0.45$ & $0.10-0.63$ & 40 & 0 & -3.2 \\
KSER & $0.05-0.65$ & $0.07-0.91$ & 40 & 0 & 0 \\
M (silt) & $0.07-0.12$ & $0.10-0.17$ & 40 & 0 & 0 \\
M (clay) & $0.09-0.14$ & $0.13-0.20$ & 40 & 0 \\
\hline
\end{tabular}

${ }^{1}$ Simulation period for sensitivity analyses, 2001-8. 


\section{Model Limitations}

Errors in model calibration can be classified as systematic or measurement errors (Raines, 1996). Systematic errors are those that arise because of the model's failure to adequately represent the hydrologic and water-quality processes of the study watershed. As a result, there are limits to how well model parameters and equations can replicate the complex physical properties of streamflow and water-quality processes.

Measurement errors are those that are introduced as a result of inaccurate or missing data. The degree to which available rainfall data represent actual rainfall is potentially the most serious source of measurement error associated with this model; limitations in the amount of available rainfall data are often a serious source of measurement error for a watershed modeling study (Ockerman and Roussel, 2009). In the lower Nueces River watershed model, rainfall was applied to the study area using data from two locations-Mathis and Robstown NWS stations. Long-term rainfall totals from these two stations are likely representative of long-term study-area conditions. However, the lack of additional rainfall gages severely limits spatial resolution of rainfall input to the 218$\mathrm{mi}^{2}$ study area, especially for relatively large runoff events. Typically, measurements of extreme values of rainfall at a single location, when used to simulate average rainfall for larger areas (such as the lower Nueces River watershed), tend to overestimate the average rainfall of the watershed (Asquith, 1999). Also, the overestimation increases as the size of the watershed increases; the fewer rain gages available for a study area, the greater the probability that rainfall in the study area is overestimated during large storms.

Another limitation of the rainfall data used for the model was that all data from the Mathis NWS station and much of the data from the Robstown NWS station were only available as daily totals. These daily totals were disaggregated to hourly values based on theoretical temporal distributions. As a result, some loss of accuracy in the timing and intensity of rainfall might have been incorporated into the model results.

Overall, streamflow was simulated with reasonable accuracy at the streamflow-gaging stations in the study area. Most of the streamflow originating in the study area was from Lake Corpus Christi releases and was measured by the Mathis gage. The Bluntzer gage was a partial-record station and did not record streamflows greater than $2,750 \mathrm{ft}^{3} / \mathrm{s}$. Similar to streamflow at the Mathis gage, streamflow at the Bluntzer gage was largely controlled by releases from Lake Corpus Christi. The accuracy of simulated streamflow at the Bluntzer gage might have been diminished during periods when additional runoff downstream from Lake Corpus Christi was occurring. Streamflow simulation results at the Calallen gage were generally very good. Low flows at the Calallen gage (streamflows of less than about $10 \mathrm{ft}^{3} / \mathrm{s}$ ) exhibited greater percentage error compared with higher flows (table 5). The errors in low flows at the Calallen gage were possibly a result of withdrawals upstream from the gage, which were only available as monthly totals. Because only monthly totals were available to represent the withdrawals upstream, hourly and daily streamflows at the Calallen gage during low-flow periods were subject to greater uncertainty compared with monthly or annual flows.

Suspended-sediment simulations also were affected by uncertainties associated with rainfall and streamflow. For example, overestimation of rainfall (in particular, rainfall intensity) would increase soil particle detachment and washoff of sediment from PERLNDs, resulting in possible oversimulation of runoff and suspended-sediment concentrations and loads.

How well the model represents basinwide suspendedsediment yields for various land types is somewhat uncertain. Calibration of basinwide suspended-sediment yields depends on reasonable estimates of sediment yields from various land types. Several studies of suspended-sediment yields for specific land types provided guidance for establishing target yields for calibration. The target yields were reasonably simulated by the model — albeit the sediment-yield studies used to establish the targets were limited in scope compared with the size of the study watershed and variety of land uses and land covers in the lower Nueces River watershed.

Overall, suspended-sediment calibration results were very good for monthly and annual suspended-sediment loads (table 10). Relatively large errors were associated with simulated daily suspended-sediment loads and with suspended-sediment load estimated for individual samples (tables 8 and 9).

\section{Estimated Suspended-Sediment Loads, by Source, to the Nueces Estuary, 1958-2010}

The calibrated model of the lower Nueces River watershed was used to estimate suspended-sediment loads to the Nueces Estuary for 1958-2010, as well as sediment loading rates (mass per unit area) and sediment loads simulated for the different land types and within different geographic areas.

The location chosen for modeling delivery of the suspended-sediment load to the Nueces Estuary was USGS streamflow-gaging station 08211502 Nueces River near Odem, Tex. (hereinafter the Odem gage) (site 11, fig. 10; table 4. The Odem gage is located in the tidal reach of the Nueces River at Interstate Highway 37, about $1.1 \mathrm{mi}$ downstream from the Calallen gage and $0.2 \mathrm{mi}$ downstream from the confluence of Hondo Creek and the Nueces River (fig. 2) (near the confluence of RCHRESs 95 and 96 or the inflow to RCHRES 97; fig. 9).

Estimated annual suspended-sediment loads, in tons per day, transported during 1958-2010 to the Nueces Estuary are shown on figure 15 and listed in table 14. The annual mean suspended-sediment load was highly variable, ranging from 


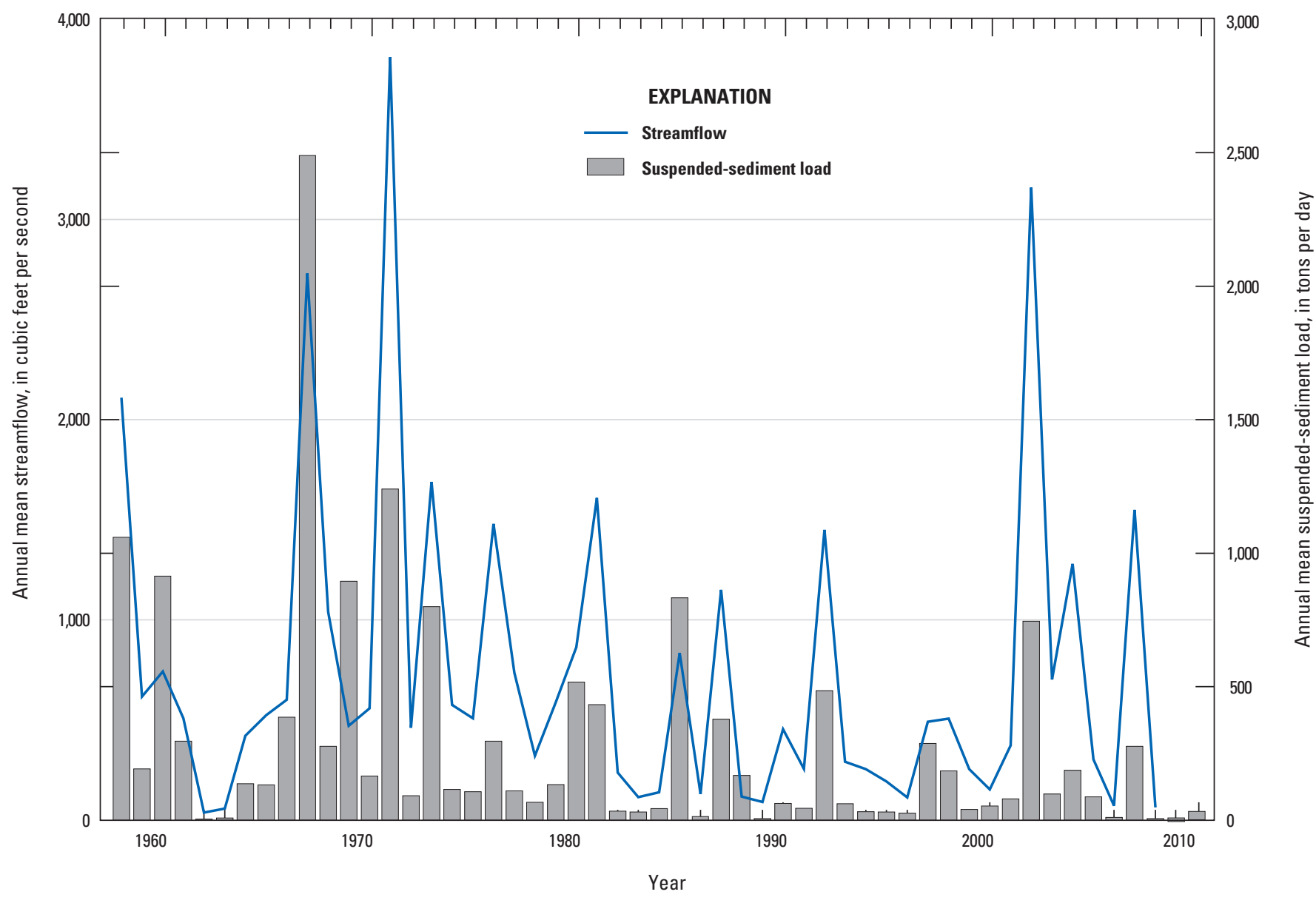

Figure 15. Estimated annual streamflow and suspended-sediment loads to the Nueces Estuary, south Texas, 1958-2010.

an estimated 3.8 tons/d in 1962 to 2,490 tons/d in 1967 . The daily mean suspended-sediment load during 1958-2010 was an estimated 297 tons/d. The median suspended-sediment load was an estimated 133 tons/d.

Estimated annual mean sediment loads at the Nueces Estuary (Odem gage) were compared with estimated sediment loads at the Mathis gage (outflow of Lake Corpus Christi) and at the Bluntzer and Calallen gages (table 15). These comparisons give an indication of sources of sediment delivered to the Nueces River and Nueces Estuary.

Estimated annual suspended-sediment loads in the lower Nueces River simulated by the model for each major source of sediment in the study area are listed by category in table 16 . On average, an estimated 288 tons/d of suspended sediment were delivered to the lower Nueces River; an estimated 278 tons/d were delivered to the Nueces Estuary. Releases from Lake Corpus Christi delivered an estimated 94 tons/d of suspended sediment or 33 percent of the 288 tons/d estimated to have been delivered to the lower Nueces River. This indicated that, on average, about 194 tons/d of sediment, or
67 percent of the estimated 288 tons/d total, were generated from erosion of land surfaces and stream-channel bed and banks. The largest source of sediment originating from within the study area was generated from cropland, about 113 tons/d, or about 39 percent of the total estimated for all sources each year, on average. Erosion of stream-channel bed and banks accounted for, on average, 45 tons/d, or about 16 percent of the estimated total suspended-sediment load. All other land categories, except cropland, accounted for an estimated 36 tons/d, or 12 percent of the total. An estimated 10 tons/d of suspended sediment or 3 percent of the suspended-sediment load delivered to the lower Nueces River were removed by water withdrawals before reaching the Nueces Estuary.

Model results indicate most of the sediment load in the Nueces River consists of silt and clay, defined as particle sizes less than 0.0625 millimeter. At the Bluntzer gage, simulated silt and clay loads composed about 99 percent of the total suspended-sediment load. At the Calallen gage, simulated silt and clay loads composed about 98 percent of the total suspended-sediment load. 
Table 14. Estimated annual streamflows and suspended-sediment loads to the Nueces Estuary, south Texas, 1958-2010.

[tons/day, tons per day]

\begin{tabular}{|c|c|c|c|}
\hline Year & $\begin{array}{l}\text { Annual mean } \\
\text { streamflow } \\
\text { (cubic feet } \\
\text { per second) }\end{array}$ & $\begin{array}{l}\text { Annual } \\
\text { suspended- } \\
\text { sediment } \\
\text { load } \\
\text { (tons) }\end{array}$ & $\begin{array}{l}\text { Annual mean } \\
\text { suspended- } \\
\text { sediment } \\
\text { load } \\
\text { (tons/day) }\end{array}$ \\
\hline 1958 & 2,110 & 215,000 & 588 \\
\hline 1959 & 617 & 70,100 & 192 \\
\hline 1960 & 742 & 334,000 & 914 \\
\hline 1961 & 508 & 108,000 & 296 \\
\hline 1962 & 38 & 1,390 & 3.8 \\
\hline 1963 & 58 & 2,820 & 7.7 \\
\hline 1964 & 421 & 50,000 & 137 \\
\hline 1965 & 524 & 48,400 & 133 \\
\hline 1966 & 601 & 141,000 & 386 \\
\hline 1967 & 2,730 & 909,500 & 2,490 \\
\hline 1968 & 1,040 & 101,000 & 277 \\
\hline 1969 & 472 & 327,000 & 895 \\
\hline 1970 & 559 & 60,400 & 165 \\
\hline 1971 & 3,810 & 452,910 & 1,240 \\
\hline 1972 & 462 & 33,400 & 91 \\
\hline 1973 & 1,690 & 292,000 & 799 \\
\hline 1974 & 575 & 42,100 & 115 \\
\hline 1975 & 509 & 39,000 & 107 \\
\hline 1976 & 1,480 & 108,000 & 296 \\
\hline 1977 & 737 & 40,000 & 110 \\
\hline 1978 & 321 & 24,500 & 67 \\
\hline 1979 & 589 & 48,600 & 133 \\
\hline 1980 & 863 & 189,000 & 517 \\
\hline 1981 & 1,610 & 158,000 & 433 \\
\hline 1982 & 238 & 12,500 & 34 \\
\hline 1983 & 115 & 11,100 & 30 \\
\hline 1984 & 139 & 15,800 & 43 \\
\hline
\end{tabular}

\begin{tabular}{lccc}
\hline Year & $\begin{array}{c}\text { Annual mean } \\
\text { streamflow } \\
\text { (cubic feet } \\
\text { per second) }\end{array}$ & $\begin{array}{c}\text { Annual } \\
\text { suspended- } \\
\text { sediment } \\
\text { load } \\
\text { (tons) }\end{array}$ & $\begin{array}{c}\text { Annual mean } \\
\text { suspended- } \\
\text { sediment } \\
\text { load } \\
\text { (tons/day) }\end{array}$ \\
\hline 1985 & 835 & 304,000 & 832 \\
1986 & 131 & 4,880 & 13 \\
1987 & 1,150 & 138,000 & 378 \\
1988 & 118 & 61,300 & 168 \\
1989 & 91 & 2,220 & 6.1 \\
1990 & 454 & 22,700 & 62 \\
\hline 1991 & 256 & 16,300 & 45 \\
1992 & 1,450 & 177,000 & 485 \\
1993 & 291 & 22,300 & 61 \\
1994 & 254 & 11,600 & 32 \\
1995 & 193 & 11,100 & 30 \\
1996 & 113 & 9,720 & 27 \\
\hline 1997 & 491 & 105,000 & 287 \\
1998 & 507 & 67,400 & 185 \\
1999 & 255 & 14,600 & 40 \\
2000 & 154 & 19,500 & 53 \\
2001 & 373 & 29,000 & 79 \\
2002 & 3,160 & 272,000 & 745 \\
\hline 2003 & 703 & 35,700 & 98 \\
2004 & 1,280 & 68,200 & 187 \\
2005 & 303 & 31,700 & 87 \\
2006 & 73 & 3,700 & 10 \\
2007 & 1,550 & 101,000 & 277 \\
2008 & 64 & 2,320 & 4.8 \\
\hline 2009 & 27 & 1,760 & 14 \\
2010 & 174 & 10,400 & 28 \\
\hline $1958-2010$ & 717 & 101,000 & 278 \\
annual average & & & \\
\hline & & & \\
\hline
\end{tabular}

Annual streamflows and suspended-sediment loads to the Nueces River and Nueces Estuary varied depending on rainfall and streamflow conditions. Annual suspendedsediment loads delivered to the estuary ranged from 3.8 tons/d in 1962 to 2,490 tons/d in 1967. Large rainfall and runoff events contributed most of the streamflow and suspendedsediment loads to the Nueces River. Whether the runoff occurred upstream or downstream from Lake Corpus Christi affected the amount of annual suspended-sediment loads that were contributed by each of the main sources shown in table 16. During some years with relatively low annual average streamflow, net stream-channel erosion was negative (1962, 1984, 1988, 1989, 1995, and 2009), indicating net annual sediment deposition to the stream channel. Simulation results

indicate that the largest sediment loads transported to the Nueces Estuary as a result of stream-channel bed and bank erosion occurred during years with relatively large annual mean streamflows (for example, 1958, 1967, and 1971). During low-flow years, relatively large percentages of the total suspended sediment transported to the Nueces River were removed by water withdrawals. For example, 2008 and 2009 were low-flow years; the annual mean streamflow of the Nueces River to the Nueces Estuary was 64 and $27 \mathrm{ft}^{3} / \mathrm{s}$, respectively, compared with annual mean streamflow of $717 \mathrm{ft}^{3} / \mathrm{s}$ measured during 1958-2010. About 44 percent and 50 percent of the total annual suspended-sediment load was removed in 2008 and 2009, respectively, by water withdrawals. 
Table 15. Estimated annual suspended-sediment loads at selected stations, lower Nueces River watershed, south Texas, 1958-2010. [suspended-sediment loads in tons per day]

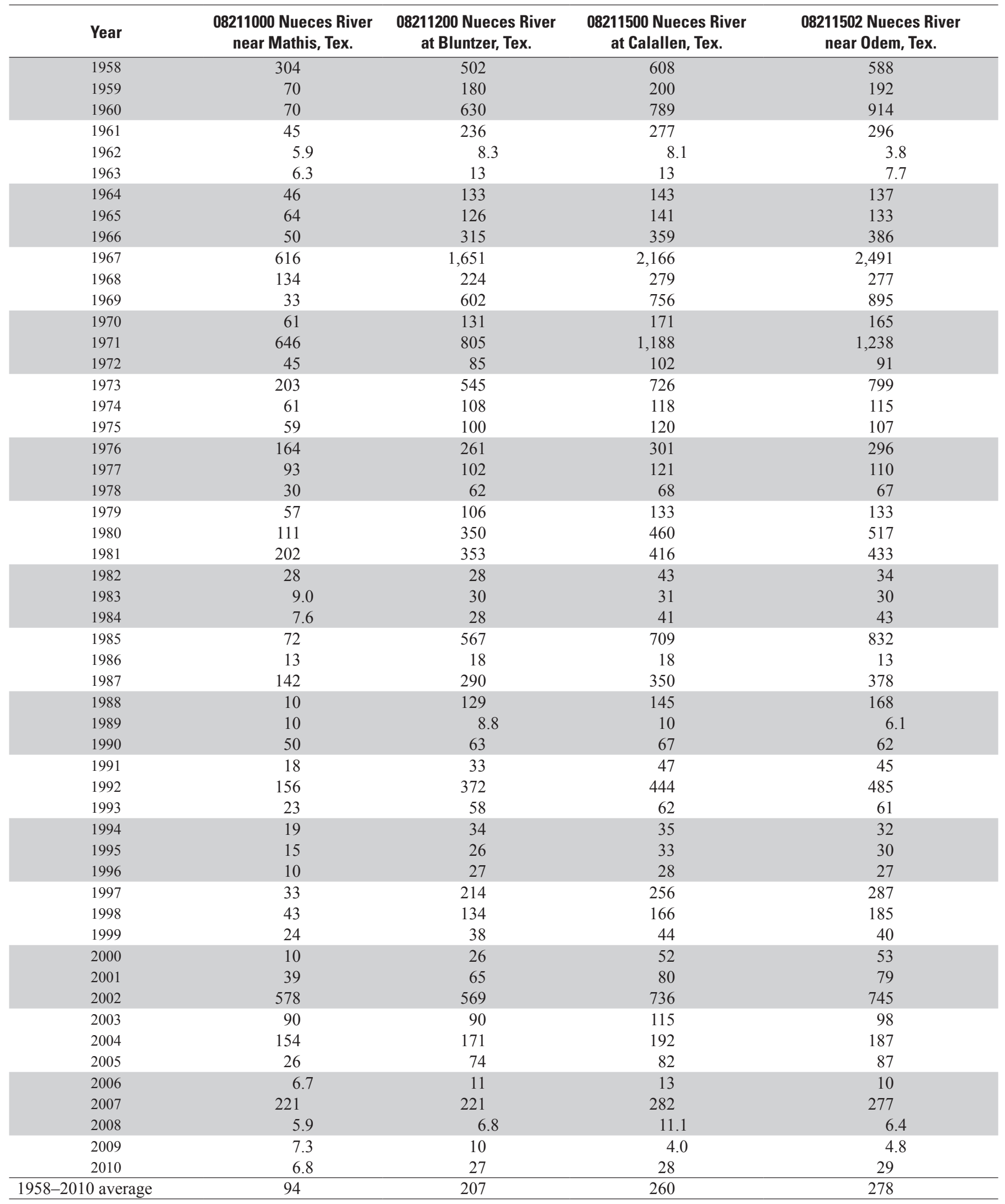


Table 16. Estimated annual streamflows and suspended-sediment loads, by sediment source, simulated by the Hydrological Simulation Program-FORTRAN model of the lower Nueces River watershed, south Texas, 1958-2010.

\begin{tabular}{|c|c|c|c|c|c|c|c|c|}
\hline \multirow[b]{2}{*}{ Year } & \multirow{2}{*}{$\begin{array}{l}\text { Annual mean } \\
\text { streamflow, } \\
\text { Nueces River } \\
\text { to Nueces } \\
\text { Estuary } \\
\text { (cubic feet } \\
\text { per second) }\end{array}$} & \multicolumn{7}{|c|}{$\begin{array}{l}\text { Suspended-sediment load } \\
\text { (tons per day) }\end{array}$} \\
\hline & & $\begin{array}{c}\text { Inflow } \\
\text { associated } \\
\text { with Lake } \\
\text { Corpus } \\
\text { Christi } \\
\text { releases }\end{array}$ & $\begin{array}{l}\text { Erosion and } \\
\text { washoff from } \\
\text { cropland }\end{array}$ & $\begin{array}{l}\text { Erosion and } \\
\text { washoff from } \\
\text { other land } \\
\text { categories }\end{array}$ & $\begin{array}{l}\text { Erosion } \\
\text { from stream- } \\
\text { channel bed } \\
\text { and banks }{ }^{2}\end{array}$ & $\begin{array}{c}\text { Total } \\
\text { transported } \\
\text { to lower } \\
\text { Nueces River }\end{array}$ & $\begin{array}{c}\text { Removal } \\
\text { by water } \\
\text { withdrawals }\end{array}$ & $\begin{array}{c}\text { Total } \\
\text { transported } \\
\text { to Nueces } \\
\text { Estuary }\end{array}$ \\
\hline 1958 & 2,110 & 304 & 26 & 18 & 240 & 588 & 20 & 608 \\
\hline 1959 & 617 & 70 & 31 & 17 & 89 & 207 & 15 & 192 \\
\hline 1960 & 742 & 70 & 677 & 114 & 82 & 943 & 29 & 914 \\
\hline 1961 & 508 & 45 & 140 & 44 & 80 & 309 & 13 & 296 \\
\hline 1962 & 38 & 5.9 & 0.0 & 4.7 & -1.8 & 9 & 5.0 & 3.8 \\
\hline 1963 & 58 & 6.3 & 0.1 & 7.1 & 0.1 & 14 & 5.9 & 7.7 \\
\hline 1964 & 421 & 46 & 15 & 9.0 & 78 & 148 & 11 & 137 \\
\hline 1965 & 524 & 64 & 6.2 & 5.0 & 68 & 143 & 10 & 133 \\
\hline 1966 & 601 & 50 & 171 & 57 & 123 & 401 & 15 & 386 \\
\hline 1967 & 2,730 & 616 & 1,236 & 416 & 234 & 2,500 & 12 & 2,490 \\
\hline 1968 & 1,040 & 135 & 39 & 15 & 99 & 288 & 11 & 277 \\
\hline 1969 & 472 & 33 & 668 & 201 & 3.0 & 905 & 10 & 895 \\
\hline 1970 & 559 & 61 & 39 & 16 & 64 & 180 & 15 & 165 \\
\hline 1971 & 3,810 & 647 & 240 & 74 & 295 & 1,260 & 16 & 1,240 \\
\hline 1972 & 462 & 45 & 6.4 & 6.6 & 45 & 103 & 12 & 91 \\
\hline 1973 & 1,690 & 203 & 384 & 132 & 101 & 820 & 21 & 799 \\
\hline 1974 & 575 & 61 & 22 & 7.5 & 32 & 123 & 7.7 & 115 \\
\hline 1975 & 509 & 59 & 37 & 11 & 20 & 127 & 20 & 107 \\
\hline 1976 & 1,480 & 164 & 38 & 13 & 94 & 309 & 13 & 296 \\
\hline 1977 & 737 & 93 & 4.1 & 3.2 & 22 & 122 & 12 & 110 \\
\hline 1978 & 321 & 30 & 18 & 10 & 15 & 73 & 6.3 & 67 \\
\hline 1979 & 589 & 58 & 37 & 15 & 33 & 143 & 9.5 & 133 \\
\hline 1980 & 863 & 112 & 304 & 88 & 26 & 530 & 13 & 517 \\
\hline 1981 & 1,610 & 202 & 124 & 44 & 77 & 447 & 14 & 433 \\
\hline 1982 & 238 & 28 & 4.3 & 4.4 & 6.2 & 43 & 8.9 & 34 \\
\hline 1983 & 115 & 9.0 & 19 & 5.2 & 3.3 & 37 & 6.5 & 30 \\
\hline 1984 & 139 & 7.6 & 32 & 11 & -2.0 & 49 & 5.6 & 43 \\
\hline 1985 & 835 & 72 & 567 & 189 & 23 & 851 & 19 & 832 \\
\hline 1986 & 131 & 13 & 0.1 & 2.5 & 2.5 & 18 & 5.1 & 13 \\
\hline 1987 & 1,150 & 142 & 147 & 52 & 46 & 387 & 9.3 & 378 \\
\hline 1988 & 118 & 10 & 155 & 19 & -6.1 & 178 & 9.9 & 168 \\
\hline 1989 & 91 & 10 & 0.2 & 2.9 & -2.6 & 11 & 4.4 & 6.1 \\
\hline 1990 & 454 & 50 & 12 & 4.7 & 2.6 & 69 & 7.3 & 62 \\
\hline 1991 & 256 & 18 & 12 & 7.9 & 14 & 52 & 6.5 & 45 \\
\hline 1992 & 1,450 & 156 & 215 & 75 & 51 & 497 & 12 & 485 \\
\hline 1993 & 291 & 23 & 24 & 11 & 11 & 69 & 7.7 & 61 \\
\hline
\end{tabular}


Table 16. Estimated annual streamflows and suspended-sediment loads, by sediment source, simulated by the Hydrological Simulation Program-FORTRAN model of the lower Nueces River watershed, south Texas, 1958-2010_Continued.

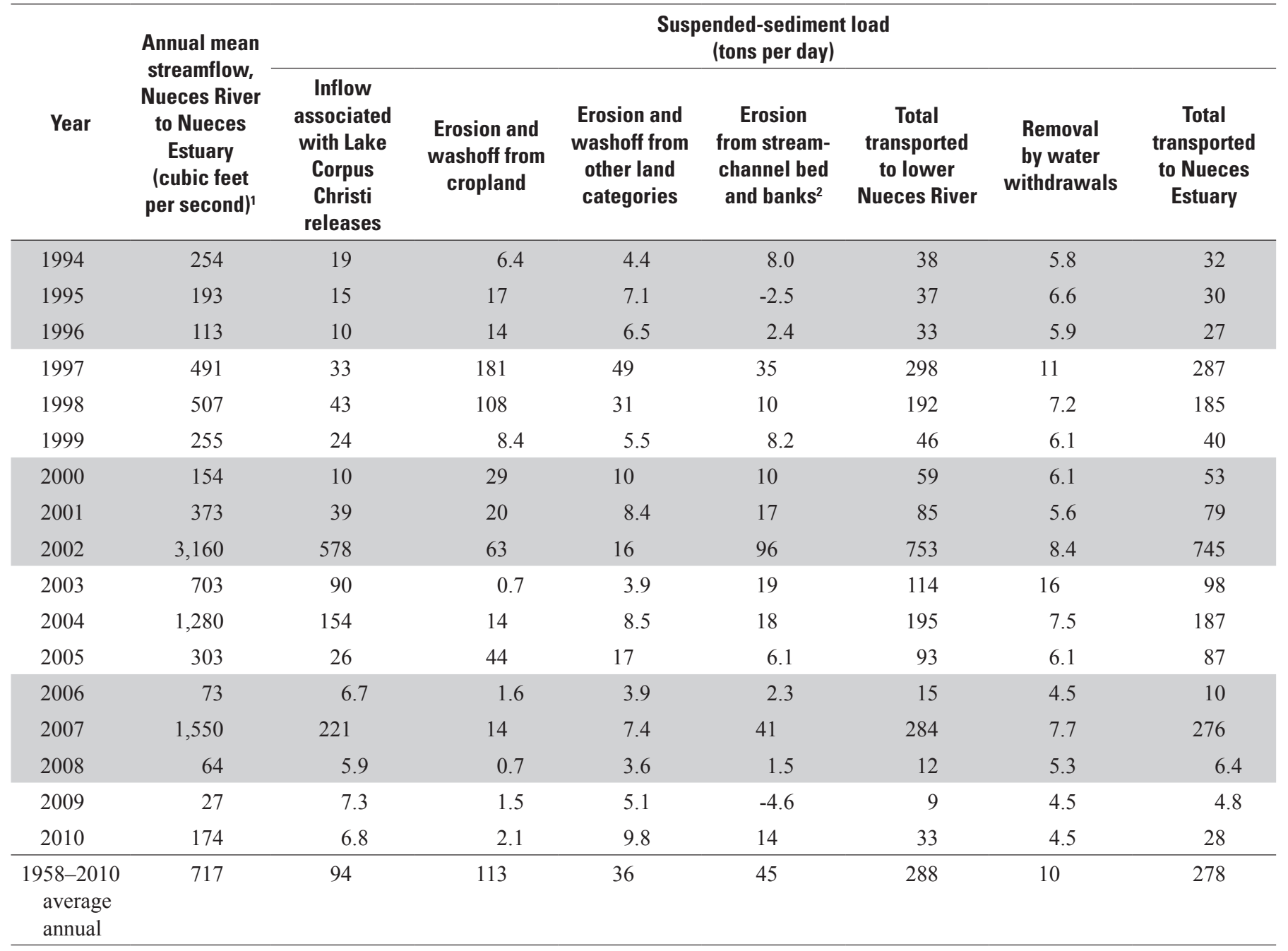

${ }^{1}$ Simulated streamflow at the Nueces River at IH-35, near Corpus Christi, Tex.

${ }^{2}$ Negative number indicates a net suspended-sediment deposition to stream reaches.

\section{Estimated Suspended-Sediment Yields by Subwatershed for Selected Runoff Events during 2009-10}

Sediment yield, a measure of the load-producing characteristics of a watershed, is computed by dividing the sediment load of the watershed by the drainage area of the watershed:

$$
Y=L / A
$$

where

$Y \quad$ is the suspended-sediment yield, in tons per acre;

$L \quad$ is the suspended-sediment load, in tons; and

$A$ is the drainage area of the watershed, in acres.
The updated model was used to estimate suspendedsediment yields for each of the subwatersheds represented in the model (fig. 9) for selected events during 2009-10. Figures 16, 17, and 18 show sediment yield (tons per acre), by subwatershed, for the runoff events of November 20-21, 2009; September 7-8, 2010; and September 20-21, 2010; respectively.

The three runoff events during 2009-10 (figs. 16-18) were characterized by relatively intense rainfall centered near the study area, generating runoff mostly in the lower Nueces watershed, with very little contribution of streamflow upstream from Wesley E. Seale Dam; therefore, nearly the entire suspended-sediment load delivered to the lower Nueces River during these events originated downstream from the dam. 

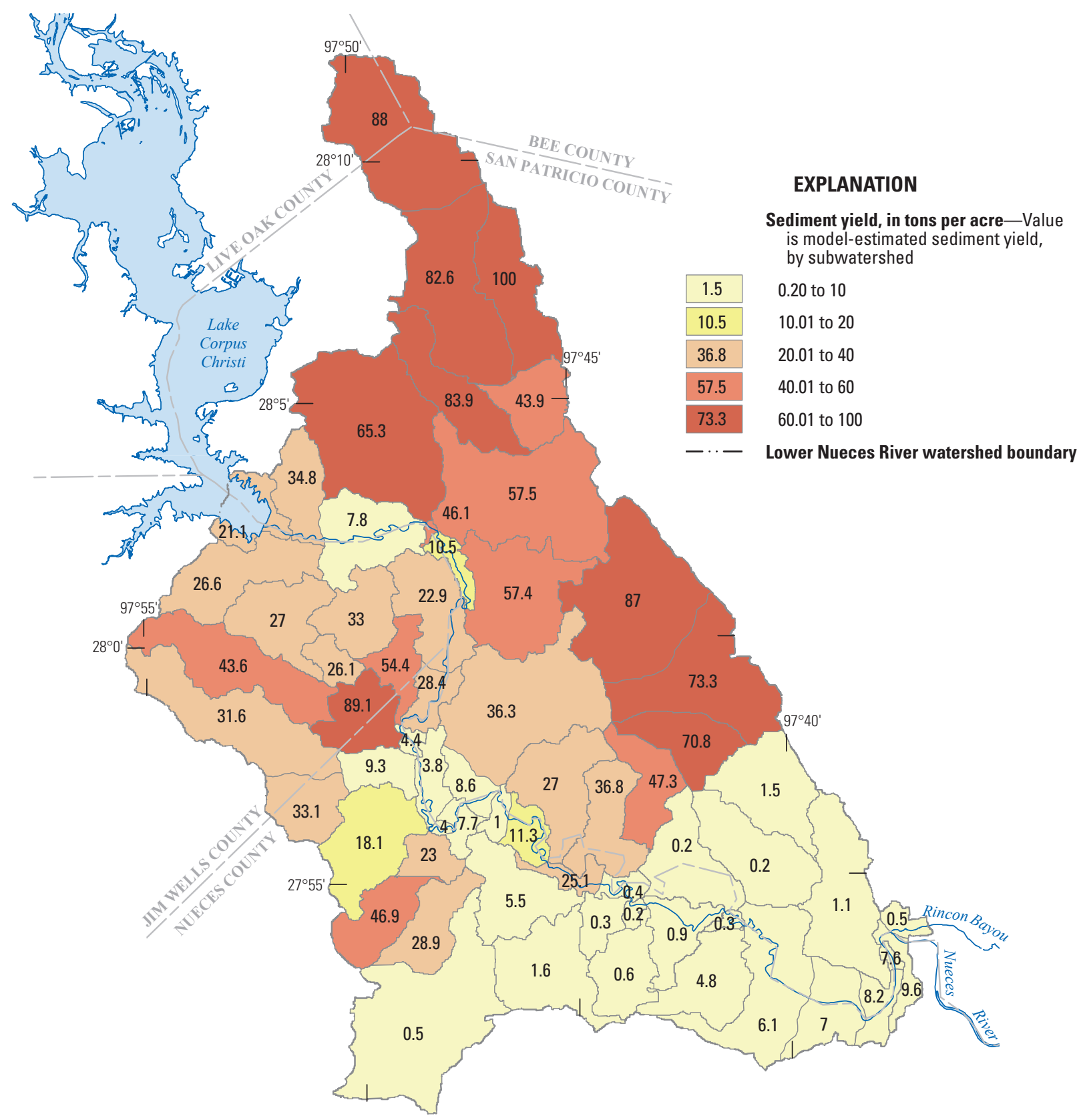

Base modified from U.S. Geological Survey digital data, 1:24,000

Texas Centric Mapping System, Albers Equal Area Projection

North American Datum of 1983

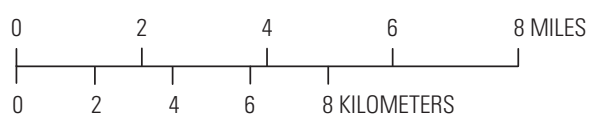

Figure 16. Model-estimated sediment yield by subwatershed for the runoff event of November 20-21, 2009, lower Nueces River watershed, south Texas. 


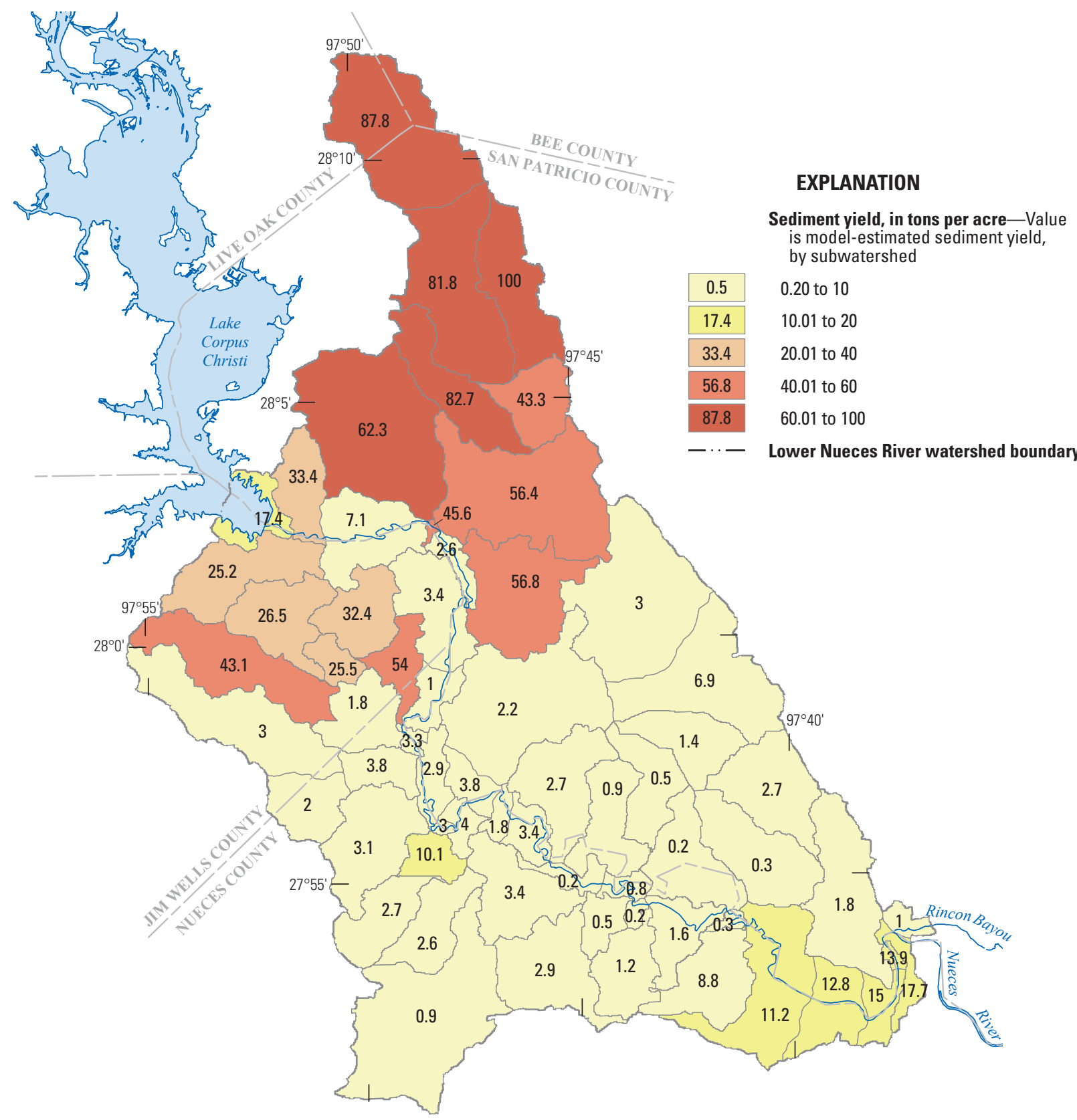

Base modified from U.S. Geological Survey digital data, 1:24,000

Texas Centric Mapping System, Albers Equal Area Projection

North American Datum of 1983

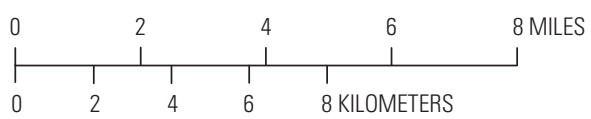

Figure 17. Model-estimated sediment yield by subwatershed for the runoff event of September 7-8, 2010, lower Nueces River watershed, south Texas. 

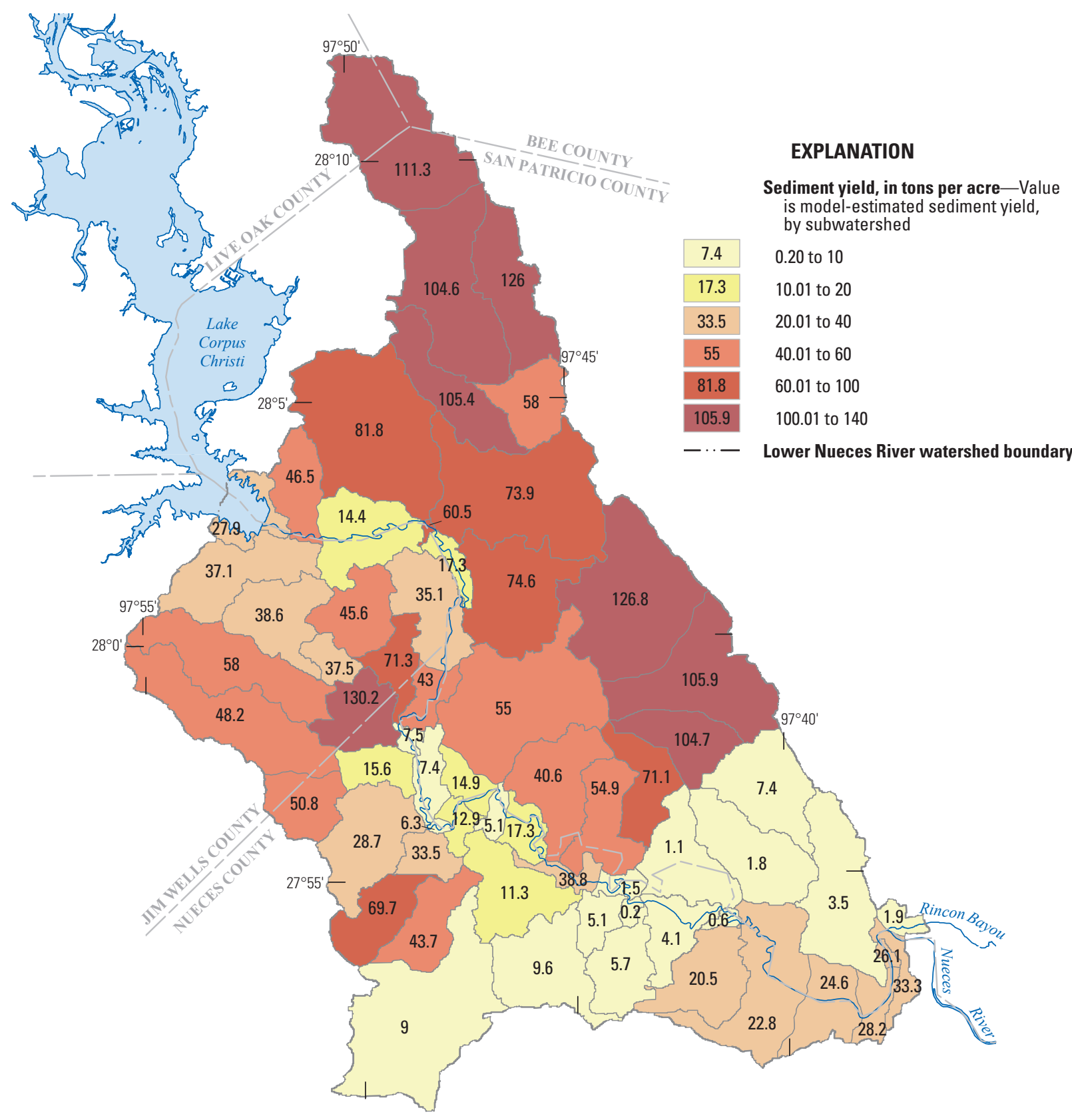

Base modified from U.S. Geological Survey digital data, 1:24,000

Texas Centric Mapping System, Albers Equal Area Projection

North American Datum of 1983

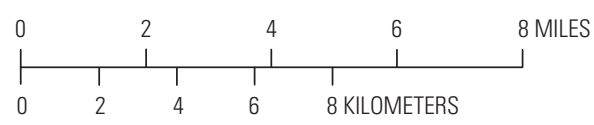

Figure 18. Model-estimated sediment yield by subwatershed for the runoff event of September 20-21, 2010, lower Nueces River watershed, south Texas. 
Sediment yields during the three runoff events were influenced by the quantity, intensity, and distribution of rainfall. The average sediment yield for the entire lower Nueces River watershed was 27.2 tons/acre during the November 20-21, 2009, runoff event; 16.3 tons/acre during the September 7-8, 2010, event; and 40.3 tons/acre during the September 20-21, 2010, event. During all three events, sediment yields generally were larger in the subwatersheds that are primarily cropland. Inspection of figures 16-18 shows that the Bayou Creek subwatersheds (model subwatersheds 9-18, fig. 9), in the northern part of the study area consistently produced some of the greatest yields of sediment. Analysis of model results for the November 2009 runoff event shows that the Bayou Creek subwatersheds contributed about 54 percent of the simulated suspended-sediment load at the primary Nueces River withdrawal locations for Corpus Christi area industrial and public supply (subwatersheds 82 and 84 , fig. 9). Runoff from the Bayou Creek subwatersheds during November 2009 was likely the primary source of suspended sediment that contributed to high concentrations of suspended sediment in the lower Nueces River during the period when the City of Corpus Christi failed to meet treatment standards for turbidity in drinking water.

\section{Summary}

The loss of sediment loading is an ecological problem in the Nueces River watershed in south Texas. The reduction in sediment loads to the Nueces Estuary is the result of sedimentation in large impoundments, notably Lake Corpus Christi, a reservoir whose storage volume was greatly enlarged in 1958 compared to its original (1935) impoundment capacity; construction in 1958 of Wesley E. Seale Dam expanded the existing conservation storage volume of Lake Corpus Christi from 43,800 to 257,260 acre-feet. The U.S. Geological Survey (USGS), in cooperation with the U.S. Army Corps of Engineers-Fort Worth District (USACE), and the City of Corpus Christi, developed, calibrated, and tested a Hydrological Simulation Program-FORTRAN (HSPF) watershed model to simulate streamflow and suspendedsediment concentrations and loads during 1958-2008 in the lower Nueces River watershed, downstream from Lake Corpus Christi to the Nueces Estuary in south Texas. The original model and report of the lower Nueces River watershed model were published in 2010.

Another issue related to suspended sediment is periods of high suspended-sediment concentration during and after runoff events. In November 2009, the City of Corpus Christi failed to meet State water-treatment standards for turbidity in drinking water because of high concentrations of suspended sediment in raw water withdrawn from the Nueces River near Calallen. At the time, the Nueces River was experiencing runoff caused by heavy rainfall in the study area. During this event, releases from Lake Corpus Christi were minimal and runoff originated almost entirely from the subwatersheds downstream from Lake Corpus Christi and the Wesley E. Seale Dam. Accordingly, the USGS, in cooperation with the USACE; City of Corpus Christi; Guadalupe-Blanco River Authority; San Antonio River Authority; and San Antonio Water System completed a study using an updated version of the previously developed watershed model to characterize sources of suspended sediment during a November 2009 runoff event and during selected runoff events in 2010 and characterized sediment yields from selected subwatersheds in the lower Nueces River watershed. During 2010, additional suspendedsediment data were collected and the model simulation period was extended through 2010. The original model calibration parameters were used along with 2009-10 input data to simulate streamflow and suspended-sediment concentrations and loads during 1958-2010.

Data available to simulate suspended-sediment concentrations and loads consisted of historical sediment data collected during 1942-82 by the Texas Water Development Board (TDWB) and its predecessor agencies at sites in the study area, and suspended-sediment concentration data collected periodically by the USGS during 2006-7 and 2010 at three sites-USGS streamflow-gaging station 08211000 Nueces River near Mathis, Tex. (Mathis gage), station 08211200 Nueces River at Bluntzer, Tex. (Bluntzer gage), and station 08211500 Nueces River at Calallen, Tex. (Calallen gage), and during 2010 at 08211050 Bayou Creek near Mathis, Tex.

During 1942-82, TWDB and its predecessor agencies monitored suspended-sediment loads of the Nueces River at a site on the Nueces River at the Mathis gage. The Mathis gage is downstream from Wesley E. Seale Dam and was completed in 1958 to impound Lake Corpus Christi. Suspended-sediment data collected before and after completion of Wesley E. Seale Dam provide insights to the effects of the dam and reservoir on suspended-sediment loads transported by the lower Nueces River downstream from the dam to Nueces Bay. Suspendedsediment loads measured at the Mathis gage decreased after completion of the dam in 1958. Annual suspended-sediment loads exceeded 100,000 tons during 9 of the 16 years before completion of the dam but only during 2 years after completion of the dam. In the 21 years following completion of the dam, for which reliable suspended-sediment data were available (1962-82), annual suspended-sediment loads were considerably lower at the Mathis gage for a given annual mean discharge than before the dam was completed.

Most of the suspended sediment transported by the Nueces River downstream from Wesley E. Seale Dam occurred during high-flow releases from the dam or during floods. During October 1964-September 1971, about 536,000 tons of suspended sediment were transported by the Nueces River past the Mathis gage. Of this amount, about 473,000 tons, or about 88 percent, were transported by large runoff events (mean streamflow exceeding 1,000 cubic feet per second). Furthermore, the suspended-sediment transport rate increases with higher magnitude flows. 
To develop the watershed model to simulate suspendedsediment concentrations and loads in the lower Nueces River watershed, streamflow simulations were calibrated and tested with available data for 2001-10. Streamflow data measured during 2005-8 at the Calallen gage were used to calibrate the model and streamflow data for 2001-4 and 2009-10 were used to test the calibrated model. Streamflow data for 2005-6 from the Bluntzer gage were used to test streamflow simulations at that site. Streamflow data from the Mathis gage were used as input to the model at the upstream boundary of the model. Simulated streamflow volumes for the Bluntzer and Calallen gages showed good agreement (within 2 and 3 percent, respectively) with measured streamflow volumes. Annual, monthly, and daily coefficients of determination of the linear regression between measured and simulated streamflow and Nash-Sutcliffe coefficients of model-fit efficiency are considered acceptable for both gages.

The HSPF model was calibrated to simulate suspended sediment using suspended-sediment data collected at the Mathis, Bluntzer, and Calallen gages during 2006-7. Soil erosion and sediment washoff from various land types simulated by the model were calibrated by comparing simulated suspended-sediment loads from the various land types to estimates of suspended-sediment runoff yields determined from other studies. Parameters related to sediment transport were calibrated primarily by comparing measured suspended-sediment concentrations and loads at the three gages with simulated suspended-sediment concentrations and loads. Evaluation of model simulation results showed that 2009-10 model simulations of streamflow and suspendedsediment concentrations and loads compared favorably with measured streamflow and suspended-sediment data.

The watershed model was used to estimate streamflow and suspended-sediment loads for 1958-2010, including suspended-sediment loads transported to the Nueces Estuary. During 1958-2010, on average, an estimated 288 tons per day (tons/d) of suspended sediment were delivered to the lower Nueces River; an estimated 278 tons/d were delivered to the estuary. The annual suspended-sediment load was highly variable, depending on the occurrence of runoff events and high streamflows. During 1958-2010, the annual total sediment loads to the estuary varied from an estimated 3.8 to 2,490 tons/d. On average, 113 tons/d, or about 39 percent of the estimated annual suspended-sediment contribution, originated from cropland in the study watershed. Releases from Lake Corpus Christi delivered an estimated 94 tons/d of suspended sediment or about 33 percent of the 288 tons/d estimated to have been delivered to the lower Nueces River. Erosion of stream-channel bed and banks accounted for 45 tons/d or about 16 percent of the estimated total suspendedsediment load. All other land categories, except cropland, accounted for an estimated 36 tons/d, or about 12 percent of the total. An estimated 10 tons/d of suspended sediment or about 3 percent of the suspended-sediment load delivered to the lower Nueces River were removed by water withdrawals before reaching the Nueces Estuary.
Annual streamflows and suspended-sediment loads to the Nueces River and Nueces Estuary varied depending on rainfall and streamflow conditions. Large rainfall and runoff events contributed most of the streamflow and suspended-sediment loads to the Nueces River.

Simulation results indicate that the largest sediment loads transported to the Nueces Estuary as a result of stream-channel bed and bank erosion occurred during high-flow years and that during low-flow years, large percentages of total suspended sediment transported to the Nueces River were removed by water withdrawals.

To help understand sources of suspended sediment during local runoff events, the updated model was used to estimate suspended-sediment yields for each of the subwatersheds represented in the model for selected events during 200910 (November 20-21, 2009, September 7-8, 2010, and September 20-21, 2010). These events were characterized by intense rainfall that occurred mostly downstream from Wesley E. Seale Dam; therefore, streamflow and suspended sediment originating from the Nueces River watershed upstream from the study area were minimal compared with runoff and associated sediment loads from the study area. Subwatersheds with the greatest sediment yield (tons per acre) during these events generally were cropland. The cropland areas of the Bayou Creek subwatersheds, in the northern part of the study area, typically had relatively large sediment loads during all three events. Analysis of model results for the November 2009 runoff event shows that the Bayou Creek subwatersheds contributed about 54 percent of the simulated suspendedsediment load at the primary Nueces River withdrawal locations for Corpus Christi industrial and public supply use. Runoff from the Bayou Creek subwatersheds during November 2009 was likely the primary source of suspendedsediment that contributed to high concentrations of suspended sediment in the lower Nueces River during the period when the City of Corpus Christi failed to meet treatment standards for turbidity in drinking water.

\section{References}

Adey, E.A., and Cook, H.M., 1964, Suspended-sediment load of Texas streams - Compilation report, October 1959September 1961: Texas Water Commission Bulletin 6410, $50 \mathrm{p}$.

Aronow, S., and Barnes, V.E., 1975, Geologic atlas of TexasCorpus Christi sheet, Alva Christine Ellisor memorial edition: Austin, University of Texas, Bureau of Economic Geology, GA0010, 1 sheet.

Aronow, S., Brown, T.E., Brewton, J.L., Eargle, D.H., and Barnes, V.E., 1975, Geologic atlas of Texas-BeevilleBay City sheet, Alexander Deussen memorial edition: Austin, University of Texas, Bureau of Economic Geology, GA0005, 5 p., 1 sheet. 
Asquith, W.H., 1999, Areal-reduction factors for the precipitation of the 1-day design storm in Texas: U.S. Geological Survey Water-Resources Investigations Report 99-4267, 81 p.

Asquith, W.H., and Roussel, M.C., 2003, Atlas of interoccurrence intervals of selected thresholds of daily precipitation in Texas: U.S. Geological Survey WaterResources Investigations Report 03-4281, 204 p.

Baird, F.C., Jennings, Marshall, Dybala, T.J., and Ockerman, D.J., 1996, Characterization of nonpoint sources and loadings to the Corpus Christi Bay National Estuary Program study area: Corpus Christi Bay National Estuary Program, CCBNEP-05, 225 p.

Bicknell, B.R., Imhoff, J.C., Kittle, J.L., Jr., Donigian, A.S., Jr., and Johanson, R.C., 2001, Hydrological Simulation Program-FORTRAN, users manual for version 12: Research Triangle Park, N.C., U.S. Environmental Protection Agency, National Exposure Research Laboratory, Office of Research and Development, 843 p.

Bidlake, W.R., 2002, Evapotranspiration from selected fallowed fields on the Tule Lake National Wildlife Refuge, California, during May to October 2000: U.S. Geological Survey Water-Resources Investigations Report 02-4055, 59 p.

City of Corpus Christi, 2013, City of Corpus Christi official web site-Lake Corpus Christi and Choke Canyon Reservoir: accessed February 28, 2013, at http://www. cctexas.com/government/water/general-info-waterqualitysupply/supply-and-planning/index.

Cook, H.M., 1967, Suspended-sediment load of Texas streams - Compilation report, October 1961-September 1963: Texas Water Development Board Report 45, 62 p.

Cook, H.M., 1970, Suspended-sediment load of Texas streams - Compilation report, October 1963-September 1965: Texas Water Development Board Report 106, 63 p.

Corpus Christi Caller Times, 2009, Corpus Christi water cited for not meeting standard: accessed November 29, 2010, at http://www.caller.com/news/2009/dec/14/corpuschristi-water-cited-for-not-meeting/.

Davis, B.E., 2005, A guide to the proper selection and use of federally approved sediment and water-quality samplers: U.S. Geological Survey Open-File Report 2005-1087, 26 p.

Day, J.W., Jr., Pont, D., Hensel, P.F., and Ibanez, C., 1995, Impacts of sea-level rise on deltas in the Gulf of Mexico and the Mediterranean-The importance of pulsing events to sustainability: Estuaries, v. 18, p. 636-647.
Donigian, A.S., Jr., Bicknell, B.R., and Imhoff, J.C., 1995, Hydrological Simulation Program-FORTRAN (HSPF), in Singh, V.P., ed., Computer models of watershed hydrology: Highlands Ranch, Colo., Water Resources Publications, p. 395-442.

Donigian, A.S., Jr., Imhoff, J.C., Bicknell, B.R., and Kittle, J.L., Jr., 1984, Application guide for Hydrological Simulation Program-FORTRAN (HSPF): Athens, Ga., U.S. Environmental Protection Agency, Environmental Research Laboratory, EPA-600/3-84-065, 177 p.

Donigian, A.S., Jr., and Love, J.T., 2003, Sediment calibration procedures and guidelines for watershed modeling, in TMDL 2003 Specialty Conference, Chicago, Illinois, November 16-18, 2003, Proceedings: Water Environment Federation, accessed January 22, 2010, at http://www.hspf. com/pdf/TMDL2003PaperDonigian.pdf.

Dougherty, J.P., 1979, Suspended-sediment load of Texas streams - Compilation report, October 1971-September 1975: Texas Water Development Board Report 233, 83 p.

Edwards, T.K., and Glysson, G.D., 1999, Field methods for measurement of fluvial sediment: U.S. Geological Survey Techniques of Water-Resources Investigations, book 3, chap. C2, 89 p.

Esri, 2009, Esri: accessed January 12, 2008, at http://www. esri.com/.

Fan, H., Huang, H.J., and Zeng, T., 2006, Impacts of anthropogenic activity on the recent evolution of the Huanghe (Yellow) River Delta: Journal of Coastal Research, v. 22, p. 919-929.

Farris, O.A., 1933, Silt load of Texas streams: U.S. Department of Agriculture Technical Bulletin 382, 71 p.

Guy, H.P., 1969, Laboratory theory and methods for sediment analysis: U.S. Geological Survey Techniques of WaterResources Investigations, book 5, chap. C1, 58 p.

Helsel, D.R., and Hirsch, R.M., 2002, Statistical methods in water resources: U.S. Geological Survey Techniques of Water Resources Investigations, book 4, chap. A3, version 1.1, accessed June 14, 2010, at http://pubs.usgs.gov/ twri/twri4a3/.

Homer, C., Huang, C., Yang, L., Wylie, B., and Coan, M., 2004, Development of a 2001 national land-cover database for the United States: Photogrammetric Engineering and Remote Sensing, v. 70, no. 7, p. 829-840.

Jaffe, B.E., Smith, R.E., and Torresan, L.Z., 1998, Sedimentation and bathymetric change in San Pablo Bay, 1856-1983: U.S. Geological Survey Open-File Report 98-759, 11 maps. 
Kelly, V.J., Hooper, R.P., Aulenbach, B.T., and Janet, M., 2001, Concentrations and annual fluxes for selected water-quality constituents from the USGS National Stream Quality Accounting Network (NASQAN), 1996-2000: U.S. Geological Survey Water-Resources Investigations Report 01-4255, accessed January 31, 2012, at http://pubs.usgs. gov/wri/wri014255/.

Kittle, J.L., Jr., Lumb, A.M., Hummel, P.R., Duda, P.B., and Gray, M.H., 1998, A tool for the generation and analysis of model simulation scenarios for watersheds (GenScn): U.S. Geological Survey Water-Resources Investigations Report 98-4134, $152 \mathrm{p}$.

Larkin, T.J., and Bomar, G.W., 1983, Climatic atlas of Texas: Texas Department of Water Resources, Limited Printing Report LP-192, 151 p.

Leibbrand, N.F., 1987, Estimated sediment deposition in Lake Corpus Christi, Texas, 1972-85: U.S. Geological Survey Open-File Report 87-239, 26 p.

Linsley, R.K., Kohler, M.A., and Paulhus, J.L., 1982, Hydrology for engineers ( $3 \mathrm{~d}$ ed.): New York, McGraw-Hill, $512 \mathrm{p}$.

Lumb, A.M., McCammon, R.B., and Kittle, J.L., Jr., 1994, Users manual for an expert system (HSPEXP) for calibration of the Hydrological Simulation ProgramFORTRAN: U.S. Geological Survey Water-Resources Investigations Report 94-4168, 102 p.

Martin, G.R., Zarriello, P.J., and Shipp, A.A., 2001, Hydrologic and water-quality characterization and modeling of the Chenowith Run Basin, Jefferson County, Kentucky: U.S. Geological Survey Water-Resources Investigations Report 00-4239, 197 p.

Minzenmayer, F.E., 1979, Soil survey of Jim Wells County, Texas: U.S. Department of Agriculture, Natural Resources Conservation Service (formerly Soil Conservation Service), 111 p., 50 map sheets.

Mirabal, J., 1974, Suspended-sediment load of Texas streams - Compilation report, October 1965-September 1971: Texas Water Development Board Report 184, 121 p.

Morton, R.A., and Paine, J.G., 1984, Historical shoreline changes in Corpus Christi, Oso, and Nueces Bays, Texas Gulf Coast: Austin, University of Texas, Bureau of Economic Geology Circular 84-6, 66 p.

Multi-Resolution Land Characteristics Consortium, 2008, National land cover database 2001: accessed June 2, 2009, at http://www.mrlc.gov/nlcd.php.

Nash, J.E., and Sutcliffe, J.V., 1970, River flow forecasting through conceptual models, part $1-\mathrm{A}$ discussion of principles: Journal of Hydrology, v. 10, no. 3, p. 282-290.
National Climatic Data Center, 2012, Comparative climatic data for the United States through 2011: Asheville, N.C., National Oceanic and Atmospheric Administration, National Environmental Satellite, Data and Information Service, accessed February 28, 2013, at http://www1.ncdc.noaa.gov/ pub/data/ccd-data/CCD-2011.pdf.

Nueces River Authority, 2013, Water usage summary: accessed April 8, 2013, at http://www.nueces-ra.org/CP/ CITY/pipeline.php.

Ockerman, D.J., 2001, Water budget for the Nueces estuary, Texas, May-October 1998: U.S. Geological Survey Fact Sheet 081-01, 6 p.

Ockerman, D.J., 2002, Hydrologic conditions and quality of rainfall and storm runoff in agricultural and rangeland areas in San Patricio County, Texas, 2000-2001: U.S. Geological Survey Open-File Report 02-291, 20 p., 1 pl.

Ockerman, D.J., and Fernandez, C.J., 2010, Hydrologic conditions and quality of rainfall and storm runoff for two agricultural areas of the Oso Creek watershed, Nueces County, Texas, 2005-08: U.S. Geological Survey Scientific Investigations Report 2010-5136, 63 p.

Ockerman, D.J., and Heitmuller, F.T., 2010, Simulation of streamflow and suspended-sediment concentrations and loads in the lower Nueces River watershed, downstream from Lake Corpus Christi to the Nueces estuary, South Texas, 1958-2008: U.S. Geological Survey Scientific Investigations Report 2010-5194, 50 p.

Ockerman, D.J., and Petri, B.L., 2001, Hydrologic conditions and water quality in an agricultural area in Kleberg and Nueces Counties, Texas, 1997-98: U.S. Geological Survey Water-Resources Investigations Report 01-4101, 36 p., 2 app.

Ockerman, D.J., and Roussel, M.C., 2009, Simulation of streamflow and water quality in the Leon Creek watershed, Bexar County, Texas, 1997-2004: U.S. Geological Survey Scientific Investigations Report 2009-5191, 50 p.

Ott, R.L., and Longnecker, M., 2001, An introduction to statistical methods and data analysis (5th ed.): Pacific Grove, Calif., Duxbury, 1,152 p.

Phillips, J.D., Slattery, M.C., and Musselman, Z.A., 2005, Channel adjustments of the lower Trinity River, Texas, downstream from Livingston Dam: Earth Surface Processes and Landforms, v. 30, p. 1419-1439.

Porterfield, G., 1972, Computation of fluvial-sediment discharge: U.S. Geological Survey Techniques of WaterResources Investigations, book 3, chap. C3, 66 p.

Quincy, R.M., 1988, Suspended sediment load of Texas streams - Compilation report, October 1975-September 1982: Texas Water Development Board Report 306, 153 p. 
Raines, T.H., 1996, Simulation of storm peaks and storm volumes for selected subbasins in the West Fork Trinity River Basin, Texas, water years 1993-94: U.S. Geological Survey Water-Resources Investigations Report 96-4110, $41 \mathrm{p}$.

Rantz, S.E., and others, 1982, Measurement and computation of streamflow-Volume 1. Measurement of stage and discharge: U.S. Geological Survey Water-Supply Paper $2175,284 \mathrm{p}$.

Salant, N.L., Renshaw, C.E., and Magilligan, F.J., 2006, Shortand long-term changes to bed mobility and bed composition under altered sediment regimes: Geomorphology, v. 76, p. $43-53$.

Singh, V.P., 1995, Watershed modeling, in Singh, V.P., ed., Computer models of watershed hydrology: Highlands Ranch, Colo., Water Resources Publications, p. 1-22.

StatSoft, Inc., 2010, Electronic statistics textbook: accessed June 5, 2010, at http://statsoft.com/textbook/.

Stout, I.M., Bentz, L.C., and Ingram, H.W., 1961, Silt load of Texas streams-A compilation report, June 1889September 1959: Texas Board of Water Engineers Bulletin 6108, $236 \mathrm{p}$.

Texas Parks and Wildlife Department, 2013, Plant guidance by ecoregions-Ecoregion 6-South Texas Brush Country: accessed February 28, 2013, at http://www.tpwd.state.tx.us/ huntwild/wild/wildlife_diversity/wildscapes/ecoregions/ ecoregion_6.phtml.

Texas Water Development Board, 2002, Volumetric survey of Lake Corpus Christi Reservoir: accessed February 28, 2012, at http://www.twdb.state.tx.us/hydro_survey/ CorpusChristi/2002-01/.

U.S. Army Corps of Engineers, 2009, Nueces River Basin Reconnaissance Study Home Page: accessed on February 28, 2013, at http://media.swf.usace.army.mil/pubdata/ notices/nueces_river_study.asp.

U.S. Bureau of Reclamation, 2000, Rincon Bayou Demonstration Project, concluding report-Volume II: Findings: Austin, Tex., Oklahoma-Texas Area Office, 299 p.

U.S. Census Bureau, 2013, American fact finder: accessed January 14, 2013, at http://factfinder2.census.gov/faces/nav/ jsf/pages/index.xhtml.

U.S. Department of Agriculture, Natural Resources Conservation Service, 2009, Soil Survey Geographic (SSURGO) database for Texas: accessed July 23, 2009, at http://soildatamart.nrcs.usda.gov/Survey.aspx?State=TX.
U.S. Environmental Protection Agency, 2006, Sediment parameter and calibration guidance for HSPF: U.S. Environmental Protection Agency, EPA BASINS Technical Note 8, accessed October 15, 2009, at http://water.epa.gov/ scitech/datait/models/basins/bsnsdocs.cfm\#tech.

U.S. Geological Survey, 2006, National field manual for the collection of water-quality data-Collection of water samples (ver. 2.0): U.S. Geological Survey Techniques of Water-Resources Investigations, book 9, chap. A4, accessed January 15, 2010, at http://pubs.water.usgs.gov/twri9A4/.

U.S. Geological Survey, 2009, National Hydrography Dataset: Get NHD Data, accessed July 3, 2009, at http://nhd.usgs. gov/data.html.

U.S. Geological Survey, 2010, USGS water data for Texas: National Water Information System (NWISWeb) data, accessed September 24, 2010, at http://waterdata.usgs.gov/ tx/nwis/nwis.

U.S. Geological Survey, 2013a, Annual water data reportDocumentation: accessed January 17, 2013, at http://wdr. water.usgs.gov/current/documentation.html.

U.S. Geological Survey, 2013b, The National MapElevation: accessed February 28, 2013, at http:// nationalmap.gov/elevation.html.

Vericat, Damia, Batalla, R.J., and Garcia, Celso, 2006, Breakup and reestablishment of the armour layer in a large gravel-bed river below dams-The lower Ebro: Geomorphology, v. 76, p. 122-136.

Welborn, C.T., 1967, Comparative results of sediment sampling with the Texas sampler and the depth-integrating samplers and specific weight of fluvial sediment deposits in Texas: Texas Water Development Board Report 36, 109 p.

Wermund, E.G., 1996, Physiographic map of Texas: Bureau of Economic Geology Map SM0005.

Wanielista, M.P., 1990, Hydrology and water quantity control: New York, Wiley, 565 p.

White, W.A., and Calnan, T.C., 1991, Submergence of vegetated wetlands in fluvial-deltaic areas, Texas Gulf Coast, in Coastal depositional systems in the Gulf of Mexico-Quaternary framework and environmental issues: Houston, Society of Economic Paleontologists and Mineralogists, Gulf Coast Section, 12th Annual Research Conference Program with Extended Abstracts, p. 278-279.

White, W.A., and Calnan, T.C., 1990, Sedimentation in fluvialdeltaic wetlands and estuarine areas, Texas Gulf CoastLiterature synthesis: Austin, University of Texas, Bureau of Economic Geology report to Texas Parks and Wildlife Department, $261 \mathrm{p}$. 
White, W.A., Morton, R.A., and Holmes, C.W., 2002, A comparison of factors controlling sedimentation rates and wetland loss in fluvial-deltaic systems, Texas Gulf Coast: Geomorphology, v. 44, p. 47-66.

Williams, G.P., and Wolman, M.G., 1984, Downstream effects of dams on alluvial rivers: U.S. Geological Survey Professional Paper 1286, 83 p.

Yang, Z., Wang, H., Saito, Y., Milliman, J.D., Xu, K., Qiao, S., and Shi, G., 2006, Dam impacts on the Changjiang (Yangtze) River sediment discharge to the sea-The past 55 years and after the Three Gorges Dam: Water Resources Research, v. 42, no. W04407, 10 p., accessed June 14, 2010, at http://www.agu.org/journals/wr/ wr0604/2005WR003970/.
Yeager, K.M., Santschi, P.H., Phillips, J.D., and Herbert, B.E., 2005, Suspended sediment sources and tributary effects in the lower reaches of a Coastal Plain stream as indicated by radionuclides, Loco Bayou, Texas: Environmental Geology, v. 47 , p. 382-395.

Yeager, K.M., Santschi, P.H., Schindler, K.J., Andres, M.J., and Weaver, E.A., 2006, The relative importance of terrestrial versus marine sediment sources to the NuecesCorpus Christi estuary, Texas-An isotopic approach: Estuaries and Coasts, v. 29, p. 443-454.

Zarriello, P.J., and Ries, K.G., III, 2000, A precipitation-runoff model for analysis of the effects of water withdrawals on streamflow, Ipswich River Basin, Massachusetts: U.S. Geological Survey Water-Resources Investigations Report 02-4018, 99 p. 

Appendix 1-Hydrological Simulation Program-FORTRAN (HSPF) Parameters Used to Simulate Hydrologic and Sediment Processes in the Lower Nueces River Watershed, South Texas 

Appendix 1. Hydrological Simulation Program—FORTRAN parameters used to simulate the hydrologic and sediment processes in the lower Nueces River watershed, South Texas.

[--, none; HSPF, Hydrological Simulation Program-FORTRAN]

\section{Pervious Land (PERLND)}

\begin{tabular}{cccc}
\hline $\begin{array}{c}\text { Secondary } \\
\text { module }\end{array}$ & Parameter & Unit & Description \\
\hline & & Water balance & \\
\hline
\end{tabular}

Interception storage

PWATER CEPSC inch Interception storage capacity

CEPS inch Initial interception storage

\section{Surface and subsurface storages}

UZSN inch

LZSN inch

SURS inch

IFWS inch

UZS inch

LZS inch

AGWS inch
Upper-zone nominal storage; an index to amount of depression and surface-layer storage of a pervious area

Lower-zone nominal storage; an index to soil-moisture-holding capacity

Initial surface storage

Initial interflow storage

Initial upper-zone storage

Initial lower-zone storage

Initial active-groundwater storage

\section{Evapotranspiration}

LZETP

AGWETP

BASETP

\section{Recession rates}

KVARY 1/inch

AGWRC 1/da

IRC $\quad 1 /$ day

GWVS inch

\section{Infiltration}

$\begin{array}{lcl}\text { INFILT } & \text { inch/hour } & \text { Index to infiltration capacity of soil } \\ \text { INFILD } & -- & \text { Ratio of maximum to mean infiltration rate of a pervious area } \\ \text { INFEXP } & -- & \text { Infiltration equation exponent } \\ \text { INTFW } & -- & \text { Index to amount of water that infiltrates and flows as interflow (shallow subsurface runoff) } \\ \text { DEEPFR } & -- & \text { Fraction of groundwater inflow to deep recharge }\end{array}$

Groundwater outflow modifier; an index of how much effect recent recharge has on groundwater outflow

Basic groundwater recession rate if KVARY is zero and there is no inflow to groundwater

Interflow recession coefficient

Index to groundwater slope 


\section{Sources of Suspended-Sediment Loads in the Lower Nueces River Watershed, Downstream from Lake Corpus Christi}

Appendix 1. Hydrological Simulation Program-FORTRAN parameters used to simulate the hydrologic and sediment processes in the lower Nueces River watershed, South Texas-Continued.

Pervious Land (PERLND)—Continued

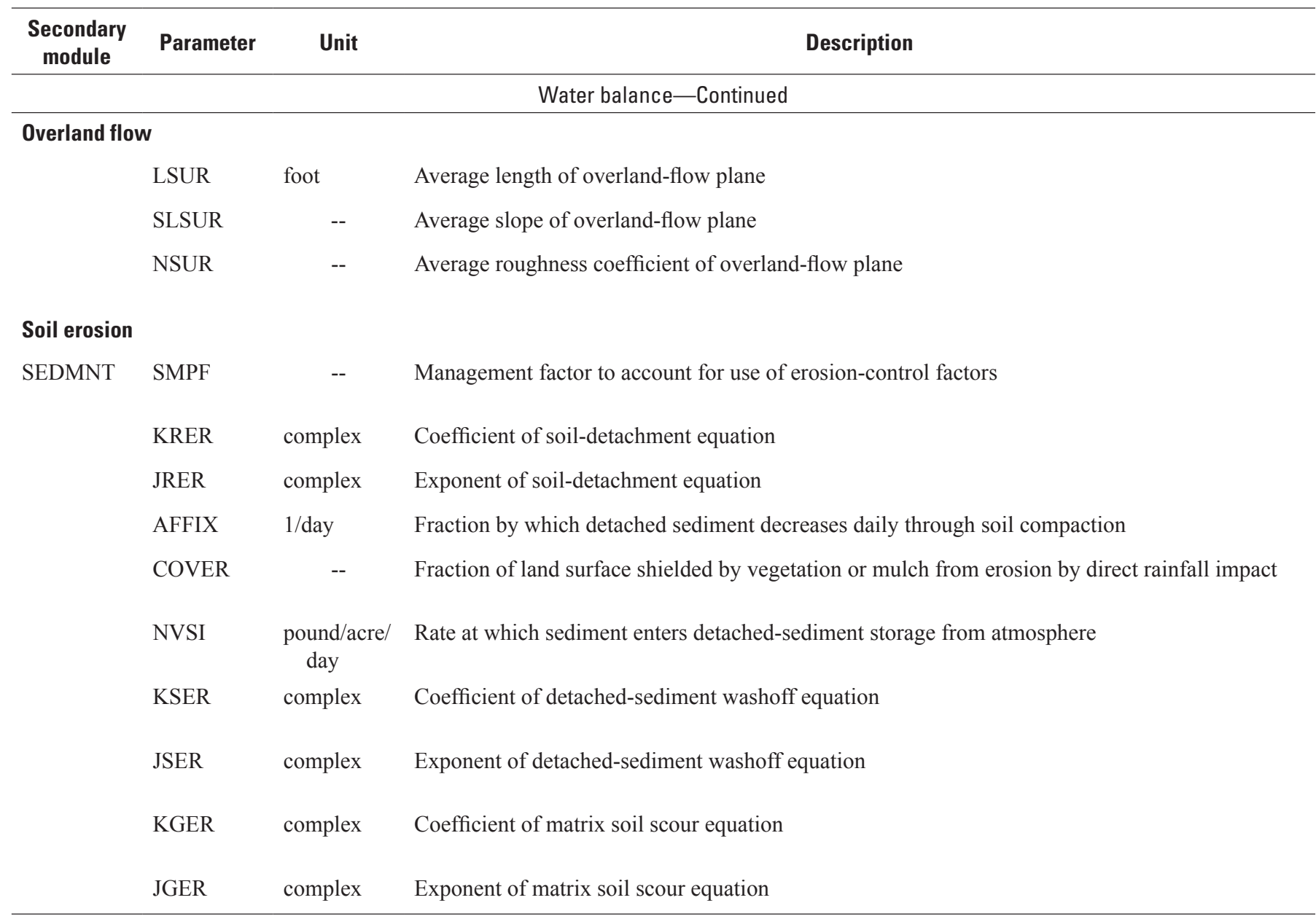


Appendix 1. Hydrological Simulation Program-FORTRAN parameters used to simulate the hydrologic and sediment processes in the lower Nueces River watershed, South Texas-Continued.

Impervious Land (IMPLND)



\section{Stream Reaches (RCHRES)}

\begin{tabular}{llll}
$\begin{array}{c}\text { Secondary } \\
\text { module }\end{array}$ & Parameter & \multicolumn{1}{c}{ Unit } & \multicolumn{1}{c}{ Description } \\
\hline HYDR & FTABNO & -- & Number of F-table that contains RCHRES geometric and hydraulic properties \\
& LEN & mile & Length of stream reach \\
& DELTH & foot & Drop in water elevation within stream reach \\
& STCOR & foot & Correction in reach depth to calculate stage \\
& KS & & Weighting factor for flow routing \\
& DB50 & millimeter & Median diameter of bed sediment \\
CRRAT & -- & Ratio of maximum velocity to mean velocity in reach cross section under typical flow conditions
\end{tabular}


Appendix 1. Hydrological Simulation Program-FORTRAN parameters used to simulate the hydrologic and sediment processes in the lower Nueces River watershed, South Texas-Continued.

Stream Reaches (RCHRES)—Continued

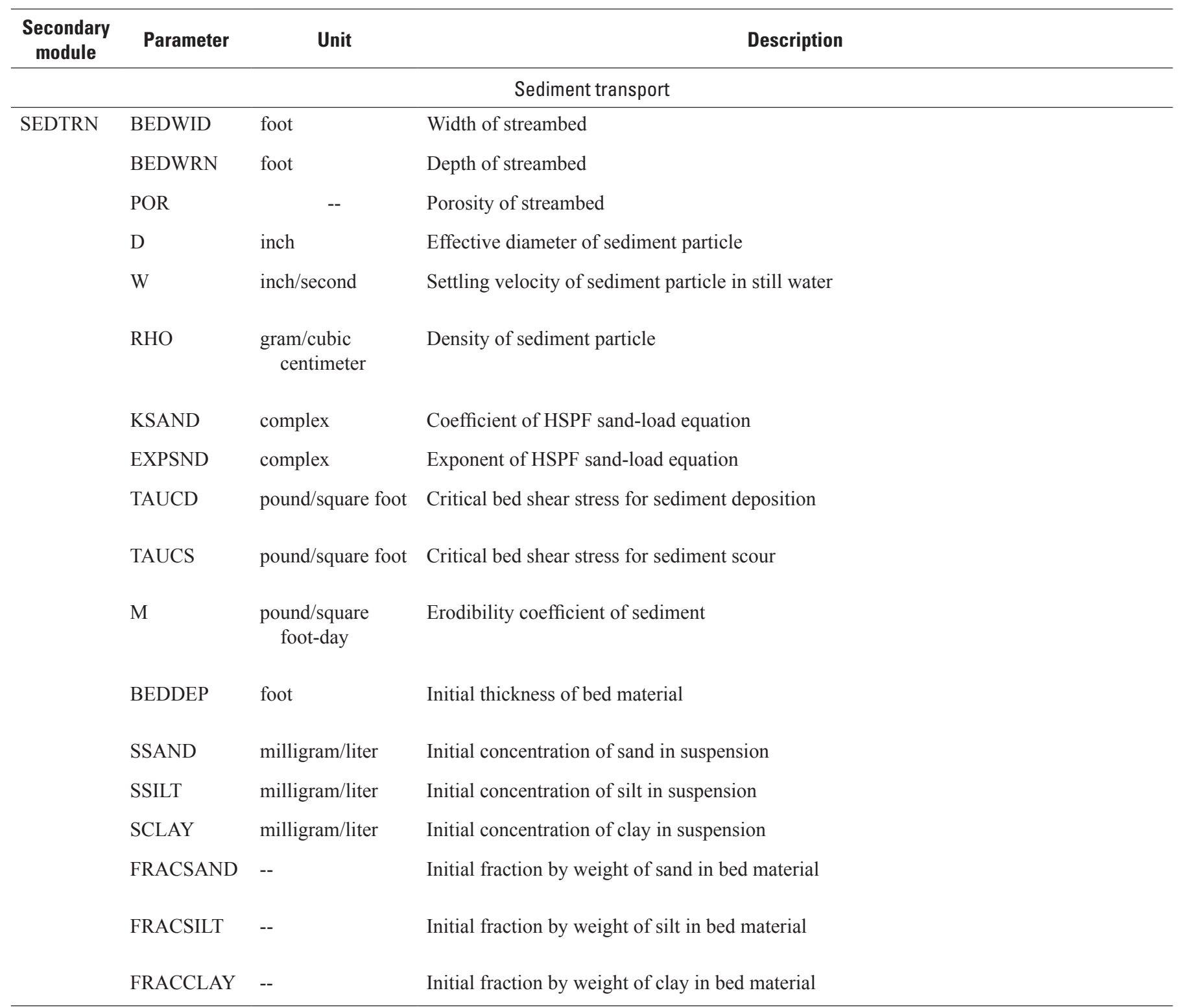

Publishing support provided by

Lafayette Publishing Service Center

Information regarding water resources in Texas is available at

http://tx.usgs.gov/ 

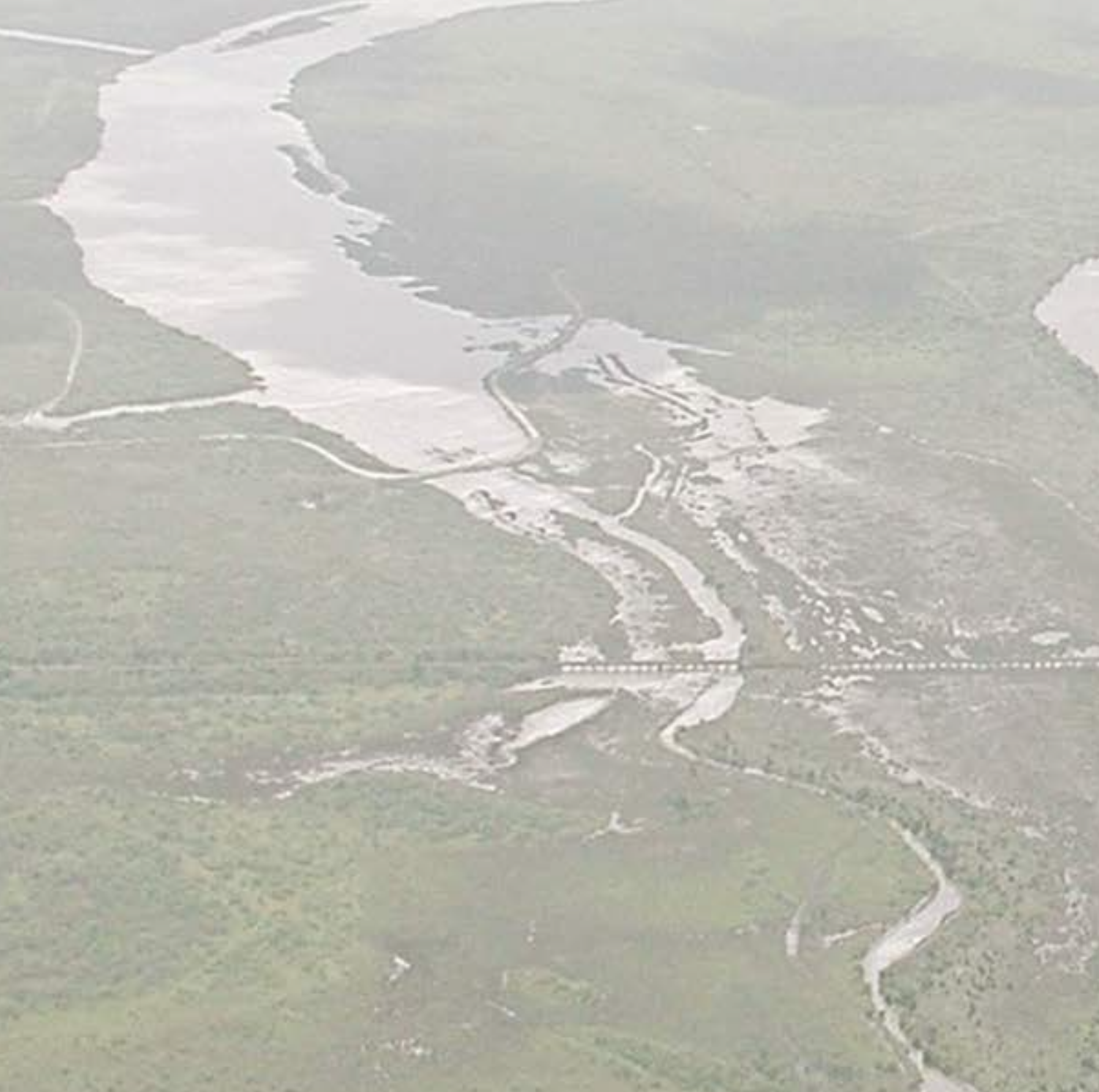

I SBN 978- 1- 4113-3584- 4 